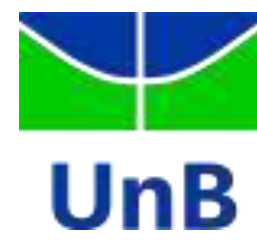

Universidade de Brasília

Instituto de Letras

Departamento de Teoria Literária e Literaturas

Programa de Pós-graduação em Literatura

CONTOS E CRÔNICAS SÉRIO-CÔMICOS DE LIMA BARRETO: UM ESTUDO DIALÓGICO DO RISO E DA SÁTIRA

Elizabete Barros de Sousa Lima

Orientadora: Ana Claudia da Silva

Brasília - DF

2016 


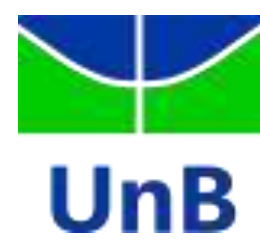

Elizabete Barros de Sousa Lima

\section{CONTOS E CRÔNICAS SÉRIO-CÔMICOS DE LIMA BARRETO: UM ESTUDO DIALÓGICO DO RISO E DA SÁTIRA}

Dissertação apresentada ao Programa de PósGraduação em Literatura do Departamento de Teoria Literária e Literaturas - TEL do Instituto de Letras da Universidade de Brasília - UnB como requisito parcial para a obtenção do título de Mestre.

Área de concentração: Literatura

Linha de Pesquisa: Estudos Literários Comparados

Orientadora: Profa. Dra. Ana Claudia da Silva 


\section{CONTOS E CRÔNICAS SÉRIO-CÔMICOS DE LIMA BARRETO: UM ESTUDO DIALÓGICO DO RISO E DA SÁTIRA}

Banca Examinadora

Profa. Dra. Ana Claudia da Silva - Tel/UnB

(Orientadora e Presidente da Banca)

Prof. Dr. Dirlenvalder do Nascimento Loyolla

(Membro Externo)

Prof. Dr. Edvaldo Aparecido Bergamo

(Membro Interno)

Prof. Dr. Anderson Luís Nunes da Mata (Membro Suplente) 
Eu dedico esta dissertação aos vermes que ainda não roeram minhas carnes: que no banquete da vida hão de celebrar a morte enquanto renascimento. 


\section{AGRADECIMENTOS}

Eis a história a ser narrada! Fundamentada na dinâmica da vida, nasceu-se a escritura; os relatos representados enunciam uma vida outra, sobre as frestas do riso e da alegria. Dentro da criação do processo, pelos laivos espaços do riso e da construção do pensar, agradeço a Ana Claudia da Silva pelo diálogo e pelos ensinamentos. Entre dois homens, essa história começou a ser tecida; dessa forma, a figura dos ideólogos - André Luís Gomes e Dirlenvalder Loyolla - tornaram-se fulcrais nessa caminhada, restando os sinceros agradecimentos. Com atores que passaram pelo verbo e criaram o corpo, a figura de Augusto Rodrigues por ela passeou e lá deixou suas marcas. Pegadas que foram recolhidas e dialogadas com Isabela de Almeida - parceira desde o limiar desta pesquisa. E se adentra a um corpo que foi germinando e cruzando vidas, como de Sylvia Cyntrão, coordenadora, professora desse programa pelo empenho e a seriedade com que trabalha; a narrativa prossegue e se depara com Maria Aparecida, Dalva Martins de Almeida, Maxçuny Alves e Clara Bonfim - amigas e companheiras dessa caminhada.

O poeta é a figura eminente da vida literária e sua poesia, a magia que encanta, leva risos e lágrimas ao homem. Dessa forma, abro brecha para agradecer ao poeta Roberto Medina - por se fazer o bobo na grande festa da vida. E se a experiência é o viver, e a aporética do riso é sua prática, agradeço a Piero Eyben, pelo sorriso e os conselhos doados. E dessa forma, seguidos pela palavra poética, agradeço ao Anderson da Mata, professor desse Departamento, pelas oportunidades e o diálogo em torno do saber. O filosofar de uma narrativa confronta mestres, e com os quais as marcas cabem em cada linha, traçam arestas que se fazem em gestos e letras. Em tais searas, são lembradas as imagens de Edvaldo Bergamo, Cíntia Schwantes, João Vianney, Regina Dalcastàgne, William Biserra, Maria Isabel Edom, Sidney Barbosa, Cláudio Braga, Junia Barreto, Hermenegildo Bastos, Rafael Villas-Boas, Ana Laura, Ana Agra, Elizabeth Hazin, Enrique Huelva - interlocutores de um mundo por vir.

Os escultores de uma história - com o perdão dos grandes mestres - são a nova geração, e o tocar vitrine é também me dizer parte dela; os louvores ficam para Pedro Couto, Lucas Lyra, Anna Isabel, Marcos Eustáquio, Marcos Eduardo, Kelly Vyanna, Janara Soares, Hiolene Champlone, Poliana Freire, Morganna Sousa Rocha, Marcos Lopes, Marcos Vinícius Caetano, Rogério Max Canedo, Douglas Rodrigues, Juliana Mantovani, João Félix, Débora Damasceno, Denise Dias, Pedro Ivo, Rosângela Lopes, 
Rosa Alda, Francisco Alves Gomes, Luiz Antônio, Douglas Martins, Thais Figueiredo, Ítalo Silva, Lemuel Gandara, Maria Aline, Ana Clara Magalhães, Luana Signorelli, Raquel Campos, Ludmila Gondim, Anne Dias, Débora Andréa, Beatriz Lopes, André Filgueira, Paula Guedes Graciane Cristina, Julliany Mucury e tantos outros - eminentes ideólogos de uma história por vir.

A vida é uma grande narrativa do homem, que, por meio da ficção, tenta se redescobrir, buscar sua outra face. Dessa forma, unem-se em um campo de investigação, onde a natureza final é reviver aquela vida, que se não vivida, ainda foi objeto de experiência de tantas outras vivências, de núcleos, em torno de um objetivo comum. Assim me revivo e alço palmas ao Grupo de pesquisa Literatura e Cultura, ao grupo Mayombe, ao Grupo Vivoverso e ao grupo Textualidades Contemporâneas: processos de hibridização dos quais me alimento constantemente dentro de suas poéticas e me reinvento em palavra. E assim, ainda nos resta o agradecimento ao Departamento de Teoria Literária e Literatura, pela pesquisa, vivência e experiência, o qual nos faz humano e nos unifica - de modos vários - a uma luta que, antes de tudo, é solidariedade: com o outro, com o próximo, com a vida.

E dessa forma volto na história, onde tudo começou e agradeço a Dona Eva, a mãe; ao Holdimar, o pai, e aos irmãos, primeiros amigos desta andança. Ainda nesta aventura, agradeço àqueles que deram os primeiros contornos dessa caminhada - Juvenal e Núbia; aos meninos, que hoje rapazes - Lucas e Jean - primos queridos que compartilhamos uma vida. Também sou grata a Conceição, a Eunice, a Júlia, ao Alisson, ao Adailton, a Ingrid, a Geovanna, a Gabriela, a Ana, a Tainá, a Núbia, a Cíntia, ao William, ao Rodrigo, a Nadir... enfim - família.

- À Capes pelo apoio financeiro para a realização desta pesquisa. 
"Leitor caríssimo, que perdoe ou dissimule as faltas que neste meu filho vires, pois nem és seu parente nem seu amigo, e tens tua alma em teu corpo e o teu livre-arbítrio como qualquer, e estás em tua casa, onde és senhor dela, como o rei de seus tributos e sabes o que comumente se diz: 'debaixo do meu manto, o rei mato', tudo o que te exime e faz livre de todo o respeito e obrigação, e, assim, pode dizer da história tudo aquilo que te parecer, sem receio de que te caluniem pela crítica nem te premiem pelo elogio que fizeres a ela.

Só gostaria de dar-ta despojada e despida, sem o ornamento do prólogo nem da inumerabilidade e catálogo dos costumeiros sonetos, epigramas e elogios que no início dos livros costumam pôr-se... Muitas vezes tomei da pena para escrevê-la, e muitas a deixei, por não saber o que escreveria; e, estando num suspenso, com o papel diante, a pena na orelha, o cotovelo na escrivaninha e a mão na face, pensando no que diria..."

Miguel de Cervantes 


\section{Resumo:}

Lima Barreto, escritor militante do limiar do século XX, trouxe para as letras brasileiras um novo foco de olhar artístico: por meio da sátira e da ironia, uniu o contexto histórico de sua época e a forma literária, marcada pela coloquialidade e o afastamento da estética simbolista e parnasiana que figurava no período. Dessa forma, partindo do pressuposto de Makhail Bakhtin sobre a carnavalização, esta dissertação busca apontar o riso como um dos principais ingredientes do projeto estético limabarretiano. Analisou-se, dessa forma, a série de crônicas Os bruzundangas, e mais três contos: "A Nova Califórnia", "O homem que Sabia Javanês" e "Apologética do feio". Diante de tais escrituras, constatouse que o prosador carioca, integrante de uma tradição de literatura do riso, apropriou-se dos modelos antigos e construiu o seu, com estética que muito se assemelha à de Gregório de Matos e à de Luciano. A sátira, enquanto forma de revelação da verdade, figurou como uma das principais fontes do riso, destronando a intelectualidade da época do escritor em nome da equalização discursiva e da revelação de uma visão de mundo (Weltanschauung).

Palavras-Chave: Lima Barreto; Riso; Carnavalização; Sátira; Conto; Crônica. 


\begin{abstract}
:
Lima Barreto, an active writer of the threshold of the twentieth century, brought to the Brazilian literature a new focus on the artistic pont of view: by means of satire and irony. Thus, he connected the historical context of his time and the literary form - plagued by the colloquial and the removal from the Symbolist and Parnassian aesthetics - which appeared in the aforementioned period. Thereby starting from "literature carnivalization" of Mikhail Mikhailovich Bakhtin, this thesis aims to identify laughter as one of the main components of Lima Barreto's aesthetic design. In this way, the following series of Brazilian literary chronicles "The bruzundangas", and three short stories: "The New California", "The man who knew Javanese" and "Apologetics of the ugly". Based on these writings, Lima Barreto not only as a prose writer from Rio de Janeiro, Brazil, but also as a member of a laughing literary heritage got hold of the old paradigms, and built his own mode of expression, with a very aesthetic like Gregório de Matos e Guerra (Brazilian poet) and Luciano de Samósata (Roman writer). The satire, as a way of bringing to the surface the truth, figured as a major source of laughter, dethroning the intelligentsia of the writer's time on behalf of discursive equalization and the revelation of a worldview (Weltanschauung).
\end{abstract}

Keywords: Lima Barreto; Laughter; Carnivalization; Satire; Short story; Chronicle. 


\section{Sumário}

INTRODUÇÃO

1. De um nariz perdido ao encontro do riso: por uma tradição literária risível . 20

1.1 Riso e filosofia. 21

1.2 A constituição do gênero romance e o riso 31

1.3 Por uma literatura do riso: alguns causos literários 40

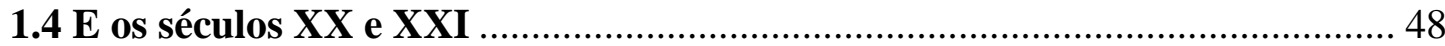

2. A literatura brasileira do riso e o projeto estético de Lima Barreto ................ 51

2.1 O riso na Literatura Brasileira 52

2.2 O legado do riso brasileiro: Gregório de Matos, Manuel Antônio de Almeida e Machado de Assis 54

2.3 Um projeto estético do riso: o caso Lima Barreto ....................................... 71

2.4 Sátira e ironia nos romances de Lima Barreto .............................................. 79

3. O riso nas crônicas e nos contos de Lima Barreto ............................................. 95

3.1 Paródia e carnavalização em Os Bruzundangas .............................................. 96

3.2 A representação do riso nos contos de Lima Barreto .................................. 113

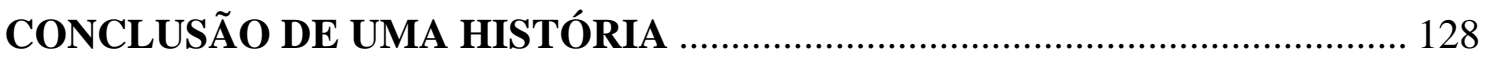

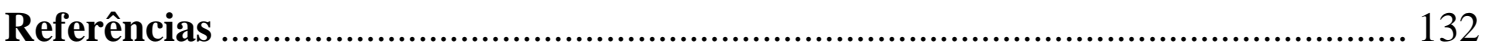




\section{INTRODUÇÃO}

“Arte e vida não são a mesma coisa, mas devem tornar-se algo singular em mim, na unidade da minha responsabilidade" (BAKHTIN, 2011, p. XXXIV). É com essa aporia que enxergamos o fundamento artístico. O escritor literário não tem compromisso em registrar a verdade dos fatos sociais, entretanto, sua vida está enlaçada por um tempo histórico embebido por ditames e problemas sociais que não o deixam se afastar do mesmo. O retrato social de uma sociedade convida muitos leitores a percorrer as páginas literárias, pois muito se sentem representados nelas; além do mais, o retrato da sociedade nas obras artísticas, às vezes, se assemelha à novela, e instiga cada vez mais o leitor a refletir sobre sua vida e a vida social da qual faz parte. Estudamos a literatura para nos conhecermos, conhecermos o outro e a sociedade na qual habitamos.

A escolha escritural de Lima Barreto parte do reconhecimento da atitude responsiva encontrada nas páginas narrativas do escritor e da ação militante que tece em sua obra, assemelhando-se a um grande retrato dos acontecimentos que marcaram o final do século XIX e o apogeu XX. A aproximação da escritura com vida, retratada nas obras de Barreto, leva-nos a mergulhar no próprio tempo de sua obra e repercute, de certo modo, no reconhecimento dos problemas culturais e filosóficos que percorrem a existência humana. Além do mais, enxergando no riso uma das principais formas de revelação da verdade, foi possível perceber esse como um dos principais fundamentos artísticos da obra do prosador. Apropriando-se da estilização e da parodização, Lima Barreto parece escolher o riso satírico como espaço essencial de revelação da realidade social de sua época; a sátira aos costumes entrelaça grande parte da obra do escritor e a ironia revela os costumes aos avessos. Tais formas de narrar aparentaram-se como as mais atraentes para esta pesquisa e justificam sobremaneira a escolha do tema. $\mathrm{O}$ riso como retrato dos costumes de um povo sinaliza a atitude responsiva da obra de arte e dirige o olhar do leitor para experenciar também aquela realidade desnudada sob a pena do romancista.

Afonso Henriques de Lima Barreto nasceu em 1881, momento em que a literatura brasileira era brindada com Memórias Póstumas de Brás Cubas, de Machado de Assis. Essa obra é considerada inaugural da literatura realista e, de alguma forma, dirige o olhar do leitor para as questões sociais e para a reflexão sobre a própria vida. $\mathrm{O}$ ano da morte do autor também foi um marco: 1922 representa o auge das manifestações modernistas, 
com a realização da Semana de Arte Moderna, em São Paulo. O viver entre esses dois importantes momentos literários e ainda integrar um período de transição e mudança nas letras brasileiras foram centrais para a constituição do projeto estético do ficcionista, o qual é visto como um dos influenciadores dos ideais do modernismo. A mistura do relato social com a necessidade de mudança estética configura a prosaística barreteana, procurando unir os acontecimentos do contexto histórico com a forma literária do período.

Os ideais literários da época pareciam caminhar na contramão do pensamento sobre representação literária de Lima Barreto: a literatura parecia haver deixado de lado os ideais de representação social que vigoraram nas duas décadas finais do século XIX. Com a atenção voltada para a estilística e o simbólico, afastaram-se bastante do retrato dos problemas sociais que culminaram na época. Em meio a tantos problemas e reconhecendo a fase pela qual o país passava Lima Barreto não se calou; suas obras, desde o primeiro escrito, Recordações do Escrivão Isaías Caminha (1909), reproduzem claramente o desajuste social do país. Mikhail Bakhtin ressalta que "a literatura é parte inalienável da integridade da cultura, ela não pode ser estudada fora do contexto integral da cultura" (BAKHTIN, 2011, p. 375). Em outros termos, a literatura integra o seio social e sua análise deve ser vista por meio do ponto de vista daquele tempo, com suas contradições e desajustes.

Por sua vez, não foram apenas os assuntos literários que constituíram a visão artístico-crítica do artista; mudanças no sistema de governo, como o fim da Escravidão e do Império e a instauração da República brasileira podem ser considerados pilares na constituição da crítica prosaica de Barreto. Quando o autor percebeu que o tempo mudava, mas a mentalidade das pessoas, conjuntamente com suas ações para a construção do país, não estava alinhada, passou a representar essa permanência do antigo no novo caricaturalmente, fazendo do riso carnavalizado o principal meio de representação social. Para o romancista, o que estava ocorrendo no Brasil era uma mudança de estrutura, aliada a um pensamento atrasado: passou-se a viver em uma nova época com hábitos do sistema anterior. Essas questões se tornaram centrais na reprodução crítica do escritor. Mikhail Bakhtin ressalta que:

O riso tem o extraordinário poder de aproximar o objeto, ele o coloca na zona de contato direto, onde se pode apalpá-lo sem cerimônia por todos os lados, revirá-lo, virá-lo do avesso, examiná-lo de alto a baixo, quebrar o seu envoltório externo, penetrar nas suas entranhas, duvidar dele, estendê-lo, desmembrá-lo, desmascará-lo, desnudá-lo, examiná-lo e experimentá-lo à vontade. (BAKHTIN, 2014, p. 413). 
As considerações do pesquisador russo, de certa forma, dialogam com o projeto estético de Barreto. Tendo o riso como norteador de suas escrituras, o romancista expõe de forma cômica os diversos contrastes sociais do período, unindo o discurso oficial com a fala e os acontecimentos do cotidiano. A comicidade é uma forma de denúncia muito utilizada pelas escrituras integrantes do campo sério-cômico, aliando os fatos penosos da vida com a narrativa alegre, satírica e de rebaixamento.

O primeiro romance de Lima Barreto parte de um projeto de riso crítico e de exposição da intelectualidade jornalística da época do escritor. Recordações do escrivão Isaías Caminha (1909) é o retrato do jovem negro que deixa sua cidade e passa a morar no centro do Rio de Janeiro. Marcado pelo preconceito, a obra se desdobra em um grande ensaio crítico sobre o ambiente jornalístico, onde imperam as máscaras sociais e o espetáculo. A exposição jocosa dos trabalhadores do recinto provocou o silêncio dos jornalistas do período do escritor, pois os mesmos reconheceram que as caricaturas da obra de Barreto eram, na realidade, a exposição dos maiores intelectuais do Correio da Manhã, um dos jornais mais importantes do período no qual Lima Barreto começou sua vida jornalística.

\footnotetext{
Efetivamente, como pouca gente letrada no Brasil hoje ignora, o romance de Lima Barreto é uma sátira ao Correio da Manhã, escolhido entre os demais por ser o de maior sucesso, o mais representativo, o mais típico, o mais retratável dos órgãos da imprensa da época. (BARBOSA, 2002, p. 195).
}

Poucos críticos, na época, falaram sobre o romance; além do mais, nenhum se ateve a elogiar a obra, restaram apenas críticas. Medeiros e Albuquerque aponta que o romancista não foi feliz em sua criação estética, pecando ao trazer para o romance muitas marcas pessoais e a imagem de pessoas reconhecidas pela sociedade. Para Albuquerque, a obra de Barreto era "um mau romance e um mau panfleto" (BARBOSA, 2002, p.197). A acolhida de Alcides Maia não foi diferente. Esse, assim como aquele, reconhece a presença marcante do personalismo na obra do carioca, ressaltando que o romance se tornou espaço de denúncias e ódio, espécie de vingança do autor contra os jornalistas da época. Segundo Francisco de Assis Barbosa (2002), "para Alcides Maia, Lima Barreto não atingira o ideal artístico colimado, justamente porque não tivera força para suprir o ódio de que se achava possuído contra o meio onde havia formado a sua personalidade" (p. 197). José Veríssimo reconhece o talento do jovem escritor, entretanto, não discorda dos anteriores no que convém ao forte personalismo levado para a obra. Segundo o crítico 
literário, Lima Barreto, infelizmente, transcreveu corretamente a vida jornalística brasileira, entretanto esse tipo de fazer artístico não lhe agradava.

Não obstante, em meio a tais desavenças, no final de 1910, Lima Barreto produzia um de seus mais renomados contos, a "Nova Califórnia". Essa escritura já se distanciava largamente da primeira obra do prosador em questões estéticas. A união entre a realidade e o insólito provocava uma nova configuração narrativa que não perdeu o roteiro do riso. O escritor começava a trilhar, nesse momento, um caminho por meio da escritura irônica; esse artifício literário parecia ser a forma encontrada para a revelação social de sua época. A criação de planos narrativos em que conjugava a exposição jocosa ora do protagonista, ora da sociedade, repudiava os acontecimentos sociais e assinalava para o rebaixamento do heroísmo cotidiano, reproduzindo o cidadão fora de suas "vestes oficiais".

Triste Fim de Policarpo Quaresma (1911) se consagra dentro do plano narrativo jocoso do escritor. A imagem do funcionário público alienado é uma grande fonte de riso do narrador: misturando o relato trágico com o cômico, Barreto assinala a construção da tragicomédia do homem no mundo. A principal crítica levantada ao longo da narrativa é o desapego da sociedade à cultura do país. Com as metáforas do cantor de modinhas, da língua, da agricultura e da guerra o narrador romanesco procura comprovar a tese de um povo aliciado pelos prazeres de fora do país, em que o estranho Policarpo Quaresma, paródia de Dom Quixote, torna-se motivo de riso de toda uma gente, sinalizando para uma grande ironia à sociedade da época e à criação de uma França no imaginário coletivo como pátria ideal.

Destarte, o segundo romance do escritor recebeu novos olhares. Mesmo não sendo recepcionado com grandes louvores pelos jornais da época, o próprio autor reconhecia que sua obra havia alcançado certo grau de perfeição. Algumas críticas positivas foram vislumbradas, especialmente dos jovens que estavam começando suas carreiras no âmbito literário. M. de Oliveira Lima, por exemplo, reportou-se duas vezes aos jornais - 1912 e 1916 no jornal Estado de São Paulo - para reverenciar a criação artística barretiana:

\footnotetext{
É um grande livro, por consenso comum. A única pecha de que o tenho ouvido culpar, não me parece absolutamente justa. Refere-se à linguagem, ou melhor ao estilo, julgado menos cuidado e por vezes incorreto, por ser a linguagem simples e propositalmente desataviada... O senhor Lima Barreto procura felizmente não escrever bonito: antes, mil vezes, antes, singelo, familiar mesmo, do que pernóstico. (LIMA apud BARRETO, 1997, p. 422-423).
}

Percebe-se que o escritor enxergou claramente, ainda em momentos de vida de Barreto, o ideal estético e a proposta de literatura militante do romancista. Além do mais, 
Oliveira Lima já apontou, naquela época, Triste Fim de Policarpo Quaresma enquanto herança de Dom Quixote de La Mancha (1605), de Miguel de Cervantes. Tais palavras, de certo modo, sinalizam a natureza risível que preenche as páginas da escritura do ficcionista. Apesar dessas respostas calorosas, o cânone literário brasileiro mantinha o silêncio sobre a obra do escritor.

Logo depois do segundo romance Lima Barreto escreve "O homem que sabia javanês" (1911). O conto é uma narrativa irônica que atravessa mais uma vez a tradição literária risível. A criação da figura do protagonista malandro, que procura meios fáceis para sobreviver é uma grande alegoria da sociedade na qual os conhecimentos vagos, subordinados pelos títulos, perfila em primeiro plano. Além do mais, a figura do malandro, já lida em Manuel Antônio de Almeida, com Memórias de um sargento de milícias, volta-se para uma tradição de literatura de rebaixamento da figura do herói, mostrado em seus momentos mais mesquinhos. As peripécias da personagem tentando sobreviver e manter a mentira do conhecimento da língua de Java é um grande espaço de riso e continua reafirmando a trajetória risível nas obras do prosaísta. Diferente, em certa medida, do primeiro romance, essas três obras mergulham na fase mais sadia das obras de Barreto, como assinala Francisco de Assis Barbosa (2002):

Aos 30 anos, Lima Barreto atingira o ponto mais alto de sua carreira literária. E produz as suas obras primas. "A nova Califórnia" é de novembro de 1910. "O Homem que sabia javanês", de abril de 1911. Foi exatamente no intervalo desses contos que escreveu o Triste fim de Policarpo Quaresma. (p. 219-220).

Além dos romances já mencionados, Lima Barreto ainda escreveu Numa e a Ninfa (1915), Vida e Morte de M. J. Gonzaga de Sá (1917) e Clara dos Anjos (1922). A última obra, que consagra a saga romanesca do artista, flagra as alegrias e misérias do subúrbio. Fruto de bastante atenção do ficcionista, o retrato dos pobres e dos negros se torna central na obra do autor. Como escritor negro, Barreto fez questão de dar voz e espaço aos excluídos da sociedade. No romance supracitado, a presença de Clara dos Anjos, mulata, enquanto protagonista, da mesma forma que Isaías Caminha, convida o espaço literário a rever seus ideais de representação e olhar para um mundo no qual o silêncio imperava. A presença do riso no romance surge desde as primeiras descrições do espaço no qual se desenrola a ação romanesca, ganhando seu apogeu na descrição satírica do malandro Cassi Jones.

Perante as produções romanescas do autor, podemos frisar que o discurso críticorisível parece integrar o enredo de todas essas obras. A comicidade aparenta ser a forma 
de revelação da verdade encontrada pelo escritor para desmascarar as leviandades sociais; do mesmo modo, a carnavalização das imagens da vida procura dar leveza à narração ao conduzir o leitor por um caminho irônico, alegre, para, posteriormente, fazê-lo refletir sobre as questões suscitadas. A atitude responsiva da obra literária procura sinalizar para as questões éticas, e o riso literário é visto como um dos meios mais profícuos do desnudamento social.

Lima Barreto produziu um grande número de contos. Tais produções, seguindo o ideal estético do escritor, procuram sintetizar um pouco dos acontecimentos e das ambivalências sociais. Marcados especialmente pelo discurso irônico, abrem espaço tanto para a crítica social por meio da sátira, quanto para planos discursivos irônicos, numa mescla entre o real e o insólito, conduzindo o leitor ao riso por meio da miserabilidade da vida e do plano filosófico que integra o conteúdo de muitos desses contos. Em "Apologética do feio" somos conduzidos ao riso por meio da pieguice de um narrador que, ao mesmo tempo que denuncia, apropria-se de recursos cômicos, como o contraste entre o espírito bom e a fealdade, para fazer o riso. Os traços risíveis na obra do romancista parecem integrar o plano estético do escritor, contrastando a vida oficial com as máscaras sociais das quais os homens se apropriam para manter suas relações.

Lima Barreto, além do romance e dos contos, escreveu um grande número de crônicas. Anteriormente à escritura de Recordações do escrivão Isaías Caminha, o escritor já mantinha a vida jornalística, iniciada no Correio da Manhã, com a série de reportagens "Os subterrâneos do Morro do Castelo". No Diário Íntimo as ruas do Rio de Janeiro ganham forma desde 1900, quando o escritor exercitava sua verve crítica sempre com o olhar satírico para o movimento das ruas e a descrição dos problemas que envolviam o subúrbio carioca. Bagatelas (1923), Marginália (1953), Feiras e Mafuás (1953), Coisas do Reino de Jambom (1956), Vida Urbana (1956) e Os Bruzundangas (1917) sintetizam, em certa medida, o olhar do intelectual para a cidade e apontam a liberdade do autor de expor sua opinião. A falta de medo dos poderes pré-estabelecidos diferencia Lima Barreto dos escritores que integravam o cânone literário brasileiro; a ação crítica presente em suas obras o afasta do espaço literário almejado - como a Academia Brasileira de Letras -, mas tais distanciamentos em momento algum foram motivos para Lima Barreto deixar de exercer seu ideal crítico.

Os Bruzundangas, reunião de crônicas de diversos momentos da vida jornalística de Barreto, pode ser lida como uma grande paródia aos fatos sociais que culminaram no Rio Janeiro. Além do mais, tal escritura, que parte da paródia da obra Arte de Furtar, é 
uma grande zombaria aos diversos seguimentos sociais do período; tendo seu limiar na descrição satírica da vida literária do local, postada no apego à sintaxe e na escritura simbólica, formas que, na concepção do escritor, se distanciavam largamente dos leitores. A arte enquanto comunicação humana, tecida sob a pena do ficcionista, se esvaía na arte simbolista e parnasiana; desse modo, a denúncia das miserabilidades do local também era deixada de lado e a literatura perdia sua função crítica. O presidente, os doutores com seus títulos, a arte em geral, a população, foram detalhadas por meio da sátira e da comicidade, apropriando-se Lima Barreto da caricatura e do rebaixamento como meios de exposição e denúncia social.

Desta forma, reconhecendo que a escritura do cronista estava vinculada a um ideal de literatura que percorre o limiar da própria história do romance, esta pesquisa perscruta as teorias de Mikhail Bakhtin sobre o surgimento do romanesco, enxergando na carnavalização a introdução de um novo conteúdo literário que contribuiu para a diferenciação da forma romance. Para o teórico a inserção do herói rebaixado no âmbito literário, diferente do elevado que se preponderava na epopeia, proporcionou a criação de uma nova estética literária gerada sob os símbolos do rebaixamento; tais representações são os espaços ideais para escrituras risíveis, uma vez que se apropriam dos contrastes sociais para a composição de suas obras.

Essa forma de olhar artístico está, de certa forma, vinculada ao pensamento filosófico do riso. As diversas transformações na forma com que as filosofias olharam para o riso refletiam diretamente na política de cada momento; os primeiros olhares para a comédia surgiram com um olhar negativo. A Idade Média foi uma das principais épocas de repressão risível; o olhar negativo para as práticas risíveis estava, de certo modo, justificado pela atitude de denúncia social que a comicidade introduzia no seio da população. O riso tem por característica principal a denúncia, a fuga dos poderes préestabelecidos, a desalienação humana e a liberdade discursiva.

A literatura brasileira, como herdeira de uma tradição ocidental de literatura, desde Gregório de Matos se apropriou dos símbolos carnavalescos enquanto forma de exposição dos problemas sociais; da mesma forma, foi, aos poucos, impregnando-se do caráter cômico como principal forma de representação literária; a figura do herói rebaixado, fracassado, que já estava na escritura de Manuel Antônio de Almeida, em meados do século XIX, foi acolhida por diversos escritores; viu seu apogeu com Machado de Assis, e se apresentou em Barreto, singularmente, por meio de uma grande sátira, que 
já não era apenas a zombaria cômica do malandro de Almeida, nem a ironia fina de Brás Cubas, mas a degradação enquanto forma de exposição dos problemas sociais.

Foi por reconhecer esse traçado risível na obra de Lima Barreto que esta pesquisa parte da concepção dos gêneros literários, uma vez que foi o romance que contribuiu largamente para a exposição risível dos contrastes sociais. A comicidade que os gêneros integrantes do campo sério-cômico apresentava por via do rebaixamento do herói, humanizava o homem e o colocava como igual aos demais cidadãos. Essa aproximação da narrativa com a vida possibilitava a revelação das características mais mesquinhas do indivíduo, conduzindo à ridicularização. Esses procedimentos estéticos, que tiveram sua raiz nos gêneros da Antiguidade, são possíveis de serem reconhecidos nas produções limabarretianas, fazendo da escritura do carioca herdeira de uma grande tradição do riso literário.

Foi nosso objetivo, nesta pesquisa, estudar as diferentes configurações do riso na obra de Lima Barreto e sua relação com os diversos gêneros literários praticados pelo escritor. Para isso tomamos como objetos específicos as crônicas Os Bruzundangas e os contos "A nova Califórnia", "O homem que sabia Javanês" e "Apologética do feio". O conteúdo, enquanto elemento essencial da comparação, perfila a natureza crítica da sátira (nas crônicas) e a irônica (nos contos). Esse fazer artístico singulariza a escritura do romancista e pluraliza seus estilos de representação. O pressuposto desta pesquisa é que a mudança do gênero pressupõe um riso diferente - A sátira cronista é justificada pelo caráter crítico e por uma consciência do cotidiano na própria circulação folhetinesca; por outro lado, os contos prezam por uma linguagem ficcional, trazendo para o leitor, por meio de personagens-ideólogos, elementos dialógicos aliados ao grotesco, ao risível e à ironia. Neste sentido, detectamos um caráter mais satírico nas crônicas e um caráter mais humorístico nos contos.

No primeiro capítulo intitulado "De um nariz perdido ao encontro do riso: por uma tradição literária risível" abordamos algumas filosofias do riso. Tais discursos filosóficos se unem à literatura uma vez que, de certo modo, ela é inseparável da cultura. Por conseguinte, mencionamos a ascensão do romance e as mudanças sociais que possibilitaram o surgimento do gênero; para ilustrar a união entre o plano filosófico e literário finalizamos nos reportando a algumas obras literárias risíveis e uma rápida reflexão sobre o riso no século XX e XIX. 
No capítulo seguinte, "A literatura brasileira e o projeto estético de Lima Barreto", procuramos fazer uma breve reflexão sobre o riso nas obras literárias brasileiras. Nos ativemos às produções de Gregório de Matos, Manuel Antônio de Almeida e Machado de Assis, reportando a importância desses autores tanto para a historiografia brasileira quanto para a produção barreteana. Finalizamos o capítulo falando dos ideais de escritura do prosaísta e ilustrando rapidamente em três romances: Recordações do escrivão Isaías Caminha, Triste fim de Policarpo Quaresma e Clara dos Anjos.

No último capítulo da Dissertação "O riso nas crônicas e nos contos de Lima Barreto", abordamos o riso satírico das crônicas na obra Os Bruzundangas e o riso irônico nos contos "A Nova Califórnia", "O homem que sabia javanês e "Apologética do feio", evidenciando, por meio da análise comparada de gêneros, que existe uma configuração estética risível diferente nesses textos propagado por meio do relato ficcional mais evidente nos contos.

Milan Kundera (1994) ressalta: "O humor: centelha divina que descobre o mundo na sua ambiguidade moral e o homem na sua profunda incompetência para julgar os outros: o humor: embriaguez da relatividade das coisas humanas; estranho prazer nascido da certeza de que não há certeza" (p. 30). O humor, revelação alegre da vida e suas contradições; as ambiguidades do mundo, são as ambiguidades humanas, onde o poder impera como discurso oficial e a obra literária vem derrubar os discursos prontos retirando suas máscaras, em uma brincadeira alegre em que conjuga o sério com o cômico e nome da revelação de uma outra da vida. As obras de Lima Barreto bem podem ser vistas dentro dessa fresta, em que o riso é a liberdade e a mudança. 


\section{De um nariz perdido ao encontro do riso: por uma tradição literária risível}

Que significa o riso? Que haverá no fundo do risível? Que haverá de comum entre a careta de um bufão, um trocadilho, um quadro de teatro burlesco e uma cena de fina comédia? Que destilação nos dará a essência, sempre a mesma, da qual tantos produtos variados retiram ou o odor indiscreto ou o delicado perfume? Os maiores pensadores, desde de Aristóteles, aplicaram-se a esse pequeno problema, que sempre se furta ao empenho, se esquiva, escapa, e de novo se apresenta como impertinente desafio lançado à especulação filosófica. (BERGSON, 1983, p. 11). 


\subsection{Riso e filosofia}

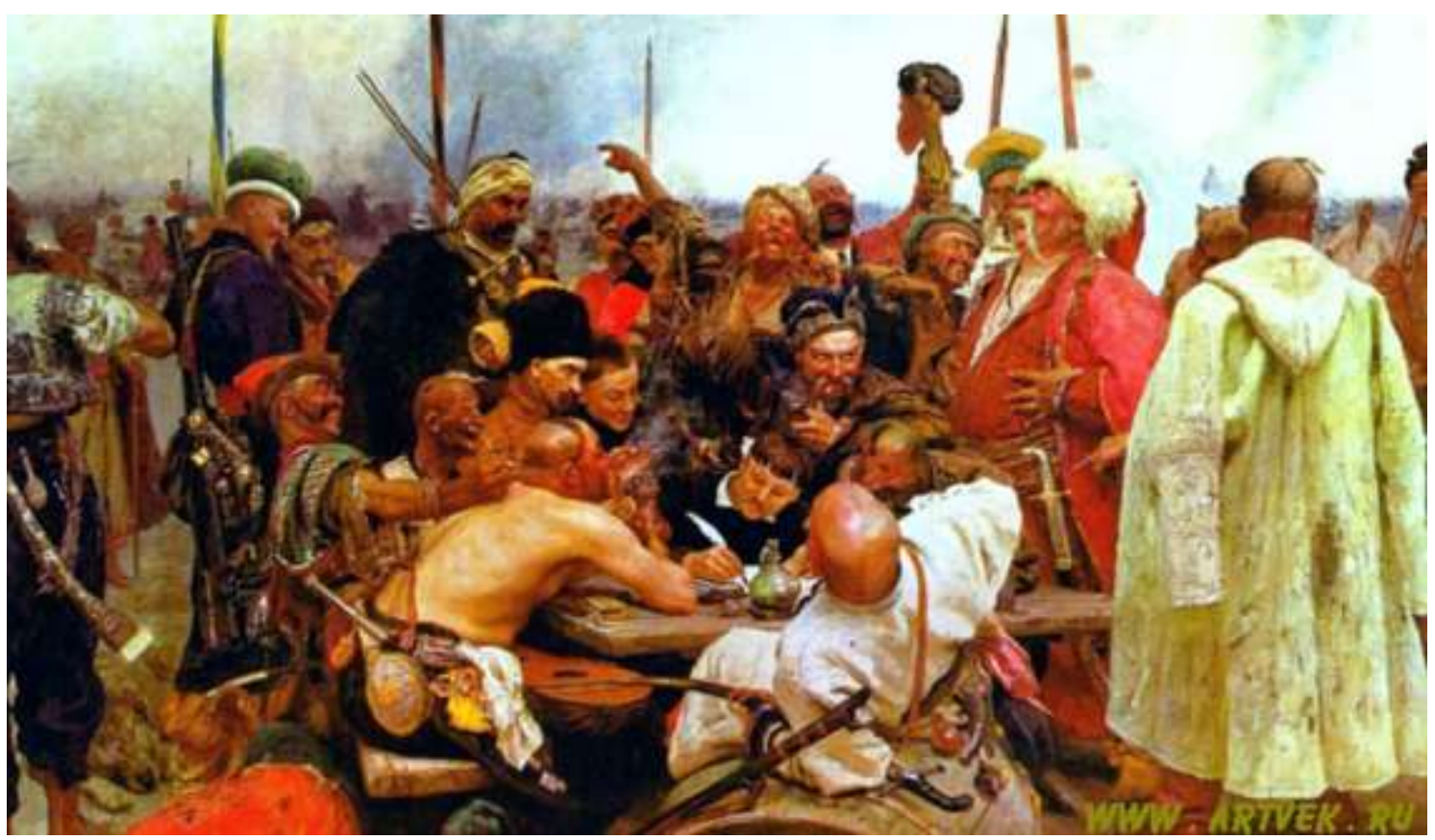

Observando o quadro acima, Os Cossacos de Zaporójie (1880-1891), do pintor ucraniano Iliá Repin ${ }^{1}$, é possível constatar formas diferentes de encarar a situação em evidência: a cena e os variados risos. Quando olhamos para as personagens que integram a imagem, percebemos distintas máscaras, sejam elas exacerbadas, contidas, satíricas, não importa a forma expressiva com a qual somos confrontados, mas interessa-nos apontar, inicialmente, como um objeto de riso pode ser passível de diferentes apreciações. Ao versar sobre a dialogia, Mikhail Bakhtin traz à tona uma das principais formas de composição discursiva, destacando a importância das relações dialógicas para a composição dos discursos; uma vez que, na perspectiva do pensador, todo discurso deriva de uma fala ou de um pensamento anterior.

No caso mencionado acima, quando se busca falar em uma tradição literária, reafirma-se a importante relação de apropriação dos discursos anteriores para a construção de um novo discurso. É dessa forma que as personagens da pintura procuram concatenar ideias sobre o quadro e as diversas máscaras apontadas, assinalando uma experiência diferente sobre os fatos da vida - o que corrobora com a diversidade de posições referentes à imagem. Dentro de tais conjunturas, podemos salientar que esse traçado dialógico se enuncia na obra pictórica do artista russo e faz, assim, jus a toda uma tradição de filosofia, que dialoga com as obras literárias e as concepções históricas sobre

\footnotetext{
${ }^{1}$ Importante pintor russo, que viveu entre os anos de 1844 e 1930, integrante do movimento conhecido como Peredvízhníki, na Rússia.
} 
o tempo vivido e o cotidiano de um povo. Dessa forma, abrimos, nesse momento, um diálogo com o riso.

George Minois, um dos maiores pesquisadores do riso, autor do aclamado livro História do Riso e do Escárnio (2003), inicia suas considerações ressaltando que o riso pode ser: “agressivo, sarcástico, escarnecedor, amigável, sardônico, angélico, tomando as formas da ironia, do humor, do burlesco, do grotesco, ele é multiforme, ambivalente, ambíguo" (MINOIS, 2003, p. 15). A partir da perspectiva de Minois, percebemos que o estudo sobre o riso se depara com diversos problemas, dadas as variadas nomenclaturas que são utilizadas para se referir ao ato do cômico. Às vezes falamos riso, outras vezes sorriso, mas também cômico, comédia, zombaria; referimo-nos, ainda, à alegria, nos mesmos termos, e quando percebemos estamos a falar sobre o mesmo tema com diversas nomenclaturas. São encontradas em vários livros referências à sátira, ao humor, à ironia; apesar disso, na maioria das ocasiões, possuem o mesmo significado. Neste trabalho não procuraremos resolver essa problemática, mas apenas trazer uma rápida reflexão sobre o sentido filosófico do riso, que se encontra acima de todas essas outras maneiras de se referir a ele.

Mas que é o riso? Existe uma definição especial para esse estilo de representação da vida e do humano? Essa é uma pergunta que acompanha a humanidade e continua se manifestando porque não se averiguou ainda uma explicação plausível para tal fenômeno. Minois ressalta que continuamos rindo das mesmas coisas que os gregos riam; as brincadeiras que marcavam o cotidiano das pessoas, os deslocamentos de olhar, o estranho - tudo isso, que selava os modos de vida da Antiguidade, permanece na contemporaneidade. É como se fosse uma manifestação social inerente à vida do homem. Todos riem, seja de alegria, seja de sarcasmo, ou mesmo o deboche, a pilhéria; são formas de expressão humana denunciadas pelos estilos narrativos de cada época. Interessa-nos destacar que é exatamente nas narrativas e nos mitos que se encontram os fios primordiais do surgimento do riso desde priscas eras da humanidade. Todavia, sabemos que as manifestações risíveis atravessaram os tempos, pois conseguimos encontrar nas manifestações contemporâneas traços daquelas mais arcaicas. Ainda assim, é necessário apontar que os modos de ver o riso se diferenciaram largamente ao longo das épocas.

Na perspectiva de Minois, os tempos passaram por três grandes momentos de concepção risível. O primeiro, presente na Antiguidade, era o do "riso divino". Nessa 
época, o riso era visto como uma arma de combate, em que as pessoas se uniam para se defender de determinado inimigo; era contemplado enquanto um riso grupal.

A concepção do riso é, então, largamente positiva. Rir é participar da recriação do mundo, nas festas dionisíacas, nas saturnais, acompanhadas de ritos de inversão, simulando um retorno periódico ao caos primitivo, necessário à confirmação e à estabilidade das normas sociais, políticas e culturais (MINOIS, 2003, p. 630).

O riso humano, nesse período, estava na aceitação da situação social em que viviam os homens, ou seja, no destino a eles dado pelos deuses.

O segundo é o "riso diabólico" presente na Idade Média - enquanto alguns pensadores da Antiguidade mantinham uma relação aceitável com as manifestações alegres, os da Idade Média procuravam abolir o riso da vida humana. Pregavam que os atos risíveis eram fruto do diabo, e os cristãos deveriam viver em constante temor para alcançarem a vida eterna.

Se o riso existe, é em razão do pecado original, que degradou a criação; o homem não coincide mais com ele mesmo. Foi o diabo que provocou essa fissura, pela qual se introduziu o riso. O diabo é ridente, zombador, eternamente distante de si mesmo, para isso foi criado (MINOIS, 2003, p. 630).

O riso desse período da história é o da subversão e tinha como objetivo norteador a superação das imposições sociais do momento. Esse estilo, às vezes, era tolerado pela necessidade de fuga do homem da vida corrente, assim como alguns religiosos o utilizavam para o bem em suas pregações, ou mesmo enquanto atitudes zombeteiras contra o mal. Após esse momento de distanciamento das práticas risíveis, deparamo-nos com o "riso humano", ligado às formas de pensamento contestatório que marcaram a Europa no período moderno. Nesse novo estilo, o "questionamento dos valores, a ascensão do medo, da inquietação e da angústia, o recuo das certezas são acompanhados por uma ambígua generalização do riso, que se insinua por todas as novas fissuras do ser e do mundo" (MINOIS, 2003, p. 631). O riso foi, então, contestador, questionando as atitudes sociais vigentes.

Em linhas gerais, o mundo foi marcado por diferentes olhares sobre o riso, não raro foi bem visto, outras vezes mal visto, mas, em geral, sua presença procura, de alguma forma, mostrar uma concepção de mundo, denunciar os valores sociais de uma população, como poderemos perceber, a partir de agora, com algumas filosofias e obras literárias que marcaram época. Inicialmente, lançamos mão de algumas ideias filosóficas para constatar 
o caminho percorrido pelo riso ao longo das épocas, para depois evidenciar essas práticas nas obras literárias.

As pesquisas contemporâneas assinalam Platão como um dos primeiros filósofos gregos a refletir sobre o riso, no caso, na obra República. Segundo Minois (2003), o filósofo renegava qualquer ato que estivesse vinculado às categorias do riso, considerando desprezíveis tanto o sujeito que ri quanto o objeto risível. Na constatação do pesquisador francês, ria-se de algo que estava fora das normas, de sujeitos que burlavam as normas impostas à sociedade. Por outro lado, o sujeito que ria o fazia por não ter conseguido e usufruído das benesses daquela prática. Para o filósofo grego, o riso, em todas as suas instâncias, era negativo, e na política, em momento algum, segundo Minois, poder-se-ia encontrar expressão risível. "A arte e a literatura nunca devem representar os homens importantes rindo: isso é degradante e solapa seu prestígio” (MINOIS, 2003, p. 72).

$\mathrm{Na}$ perspectiva do filósofo grego Aristóteles, no entanto, o cômico também apresentava suas manifestações positivas, estando associado à felicidade, à alegria, no sentido de cultivar e tornar os momentos de conversa agradáveis. Todavia, Aristóteles, assim como Platão, renunciava à atitude risível que visasse ao rebaixamento: "Aristóteles rompe completamente com o riso arcaico, zombeteiro, agressivo e triunfante" (MINOIS, 2003, p. 72). As perspectivas apresentadas anteriormente estão diretamente relacionadas à representação presente na Poética (1999), ou seja, a tragédia, ligada ao sério, deveria representar os grandes homens; no caso da comédia, dominada pelo riso, deveria representar os homens fracos de caráter. "Pois a mesma diferença separa a tragédia da comédia: procura esta imitar os homens piores, e aquela, melhores do que eles ordinariamente são" (ARISTÓTELES, 1999, p. 105).

A filosofia latina guarda seus pressupostos sobre o riso principalmente no pensamento dos autores Cícero e Quintiliano, os quais aliaram a prática risível à oratória, encontrando uma outra perspectiva para o cômico, que chamaria a atenção das pessoas para o que estava sendo dito. Sob essa abordagem, o riso serviu enquanto modo de aproximação do orador a seu público e não simplesmente pelo viés da criticidade e do lado negativo atribuído à derrisão.

$\mathrm{Na}$ Idade Média, as concepções sobre os atos risíveis produziram uma longa disputa de pensamentos, uma vez que repousavam uma visão séria e outra cômica do mundo. A força da Igreja Católica como a entidade de grande poder sobre as formas de pensamento que foram se construindo, baseava-se no diálogo cristão e na ideia de que Deus nunca riu; por meio do poder absolutista que detinha dentro dos territórios cristãos, 
o catolicismo contestou e reprimiu os atos risíveis que estavam se instaurando nos meios sociais. Negando o caráter contestador do riso manifestado ao longo dos tempos, ressaltava que o riso rememorava as crenças politeístas e as práticas "negativas" e que os cristãos deveriam viver em constante estado de temor e solidão para encontrarem felicidade e alegria após a morte. Entretanto, esses mandamentos nunca foram postos em prática na totalidade. As pessoas, por exemplo, realizavam constantes festas para a celebração dos mortos. Também era comum e motivo de críticas e denúncias a realização de festas e ritos situados nas proximidades das igrejas e, em determinadas ocasiões, com a participação de religiosos. O temor à morte e a busca pelos atos mundanos foram sempre postos lado a lado na vida dos cristãos, alimentados por uma postura séria e reanimados pela visão cômica do mundo.

O pensador russo Mikhail Bakhtin (1895-1975), por sua vez, também tece considerações sobre o riso na Idade Média. Segundo o teórico, o riso representava parte essencial da cultura popular, caracterizado por sua expressão carnavalesca e ambivalente, consagrado nos rituais de destronamento, unindo o sentido de morte com o de renascimento como alegorias do fim de uma estrutura velha para o erguimento de uma nova. O ritual, semelhantemente, era utilizado para o questionamento das estruturas sociais e de poder da população, visando trazer uma outra visão de mundo contrária à que a Igreja procurava mostrar aos cristãos. Minois (2003), ao falar sobre um tipo de riso de protesto da época, destaca:

O riso do goliardo ${ }^{2}$ é o único riso subversivo da Idade Média Clássica, porque não se contenta em zombar: ele vive de maneira diferente e sugere, com isso, que é possível existir outro sistema de valores. O riso da festa dos bobos ou do carnaval mostra a loucura de um mundo às avessas" (MINOIS, 2003, p. 188).

Nessa época, os pensadores que se dedicaram a tratar do riso trouxeram seus pensamentos muito aliados ao que a Igreja pregava, destacando o cômico sempre em sua forma mais baixa. "O riso não é natural no Cristianismo, religião séria por excelência. Suas origens, seus dogmas, sua história o provam" (MINOIS, 2003, p. 111). Aqui nos atemos a evidenciar a presença de Santo Ambrósio, Santo Agostinho, Clemente de Alexandria e João Crisóstomo, pensadores totalmente vinculados à igreja, que mantinham

\footnotetext{
${ }^{2}$ Grupo farsista derivado da cultura escolar universitária. "Utilizando-se do latim, eles compõem canções, os carmina burana, farsas, missas parodísticas, sermões báquicos. Qualificados, às vezes, de jograis, bufões, ribaldos ou vagabundos (MINOIS, 2003, p. 186).
} 
perspectivas contrárias à exalação de pensamentos que objetivassem defender a presença do cômico enquanto elemento essencial e inseparável ao humano.

Logo após o momento de repressão, no século XVII, como aponta a pesquisadora Camila da Silva Alavarce, "percebe-se uma tendência a associar o riso ao não sério, às tolices" (ALAVARCE, 2009, p. 81). Uma das principais vozes a discorrer sobre o modo risível desse período, segundo Alavarce, foi Laurent Joubert, em seu Tratado do riso. Diferente dos pressupostos negativos presentes na Idade Média, Joubert não possuía um olhar negativo para as práticas risíveis; entretanto, ainda não encontramos nesse período a essência do riso, pois, para o autor do Tratado, o riso estava associado às atitudes não sérias do homem. Em outras palavras:

Joubert permite que se ria da deformidade, do comportamento do outro, de sua tolice e ingenuidade, sem a presença sufocante da condenação ética do riso. Assim, em razão de estar sempre associado às atitudes frívolas e sem importância, não há prejuízos para o objeto do riso. Sem graves danos, também ficam de fora os sentimentos de piedade ou remorso (ALAVARCE, 2009, p. 82)

O tratado de Joubert tornou-se de grande importância para os estudos sobre o riso na sua época e nas que a sucederam, constituindo duas formas diferentes de concepções risíveis. Seu tratado passou a ser intitulado "Riso Clássico", em oposição a uma nova conceituação que estava surgindo e que marcou o século XVIII. Nessa segunda acepção, o riso passou a ser entendido "como manifestação de superioridade, ou como contraste ou incongruência" (ALAVARCE, 2009, p. 82). O século XVIII, por sua vez, viu o riso principalmente pelo viés negativo, marcado por fissuras que atribuíam aos atos risíveis a “deformidade e o desvio". O grande pensador desse século acerca do cômico foi Thomas Hobbes, que trouxe conceituações de um possível riso benevolente ao rastrear a presença da comicidade ligada ao orgulho e ao grau de superioridade do sujeito que ri em relação ao objeto do riso, o qual assinala sempre um olhar sobre o defeito do outro, configurando uma espécie de condenação ética sobre o mesmo. "O riso figura aqui como manifestação grosseira da superioridade de quem ri, tornando-se, por conseguinte, um instrumento de poder" (ALAVARCE, 2009, p. 83). O riso, por fim, constrangeria seu objeto, uma vez que sua exposição, fruto dos atos de rebaixamento, era marcada por qualificativos negativos.

Enquanto Hobbes se voltava, novamente, à condenação do riso, Anthony Ashley Cooper, conhecido como Conde de Shaftesbury, trouxe uma nova visão para os atos risíveis e procurou uni-lo à religião. Se desde os tempos medievos esses dois polos se 
distanciaram e assistiu-se à igreja proibindo qualquer tipo de manifestação do risível, agora, mais uma vez, tê-lo-emos face a face em uma tentativa de reconciliação. A proposta do Conde de Shaftesbury era trazer o riso como instrumento da fé, possibilitando ao riso agressivo uma busca de equilíbrio e razão. Em outros termos, "nas reflexões do conde de Shaftesbury, o riso é visto, pois, como uma arma de combate às verdades preestabelecidas. O riso é um instrumento sério de questionamento e deve ser utilizado de modo racional e equilibrado" (ALAVARCE, 2009, p. 85). Quando estamos diante desse estilo de olhar, percebemos o quanto as formas de enxergar o riso se transformaram e ganharam novas facetas, abrindo a possibilidade de compreendê-lo como meio de questionamento e desnudamento das estruturas sociais. A partir da perspectiva proposta pelo filósofo, tal visada enunciava a grande reviravolta nos estudos sobre o riso que marcaram o século XIX.

Minois (2003) ainda destaca que o Conde trouxe uma grande abertura ao riso após o momento de repressão e ocultamento: "Shaftesbury defende a liberdade de zombar, a liberdade de questionar tudo, em uma linguagem decente, e a permissão de esclarecer e refutar qualquer argumento sem ofender o interlocutor" (p. 451). Ilustrando a questão exposta pelo Conde: quando o locutor fecha seu discurso apontando a impossibilidade da ofensa, pressuposto questionável, percebemos como ele se volta para o olhar dedicado ao bobo da corte, momentos em que a bufonaria, a ridicularização e o rebaixamento não levavam à ofensa, mas apenas ao divertimento e, através desse divertimento, a uma forma de reflexão sobre os atos sociais.

O século XIX foi um marco para o estudo do riso. Apresentaram-se uma série de reflexões filosóficas que aliavam à própria concepção de mudança dos tempos e da cultura. O riso dessa fase foi, ao mesmo tempo, contestador e satírico, procurando delinear as misérias sociais e a despreocupação de um sistema político que não estava centrado em solucionar os problemas da sociedade, destacando, como característica norteadora, a insatisfação por uma ordem que não correspondia ao ideário social em voga. Segundo Alavarce (2009), para os autores desse tempo, o riso possuía como característica essencial o sério, a procura de novos caminhos. É importante salientar que essa época marca a ascensão da filosofia, sob a luz, principalmente, dos pensamentos de Immanuel Kant (1724-1804), e do entendimento do mundo por meio da razão. Dentre a variedade de pensadores do riso nesse período, podemos apontar a presença de Georg Wilhelm 
Friedrich Hegel, Friedrich Wilhelm Nietzsche, Henri Bergson, Sigismund Schlomo Freud, Johan Friedrich Richter e Charles Baudelaire.

O pensamento de Hegel (1770-1831) sobre o riso encontra-se no Curso de Estética. Nesse estudo, pode-se perceber a negação dos elementos do riso em nome dos atos sérios, o filósofo justifica sua postura por enxergar no cômico o rebaixamento de todas as coisas, e percebendo no ato irônico a negação da própria existência. Em contraponto, na ótica de Nietzsche (1844 - 1900), o riso é a forma que o homem, sofredor das misérias mundanas, encontrou para sobreviver a elas, para fugir das situações de tristeza e desapego da vida. Sobre Nietzsche, Minois (2003) ressalta que a obra pessimista do filósofo:

É permeada de aforismos sobre o riso. Leves em todos os sentidos, são extravagantes e parecem, às vezes, contradizer-se. Dão uma impressão geral de nostalgia e uma vontade de rir de tudo e contra tudo, por que o riso é a única tábua de salvação, é a redenção (MINOIS, 2003, p. 520).

Sigmund Freud (1856-1939) foi outro pensador que procurou, por meio do estudo da natureza do homem, apresentar suas postulações sobre o cômico. Ao ressaltar o humor como forma elevada do riso, o psicanalista salienta, em seu primeiro trabalho, Os chistes e sua relação com o inconsciente, que o riso conduz o sujeito ao prazer, por retirar a pessoa dos aspectos penosos e da dor. Nesse sentido, o humor é encarado como "um processo de defesa que impede a eclosão do desprazer" (MINOIS, 2003, p. 526). O humor seria a elevação do indivíduo sobre os fatos mundanos, o momento de superação das práticas sociais, possibilitando a leveza e a saúde psíquica.

Henri Bergson (1859-1941), por sua vez, destaca que o riso deve estar atrelado aos fatores sociais da vida do homem, pois: "O riso deve corresponder a certas exigências da vida em comum. O riso deve ter uma significação social" (BERGSON, 1983, p.14). O riso para o filósofo não é fruto de uma única pessoa, mas manifesta-se em uma cultura, sendo exatamente o acordo social firmado entre os indivíduos que o ocasiona. Por sua vez, a manifestação do risível surge exatamente do deslocamento de ação de determinado sujeito, passando a ser considerada sua atitude estranha ao grupo social ao qual pertence. A incongruência entre o pensado e o realizado tornam-se os principais motivos que conduzem ao estranhamento que, por sua vez, leva ao riso. Nesse sentido, o pensamento do filósofo "é marcado pelo florescimento da sociologia e pela renovação da espiritualidade, o que o leva a elaborar uma teoria do riso como manifestação de um 
ímpeto vital." (MINOIS, 2003, p. 522). Para além disso, o riso vem com o objetivo de derrubar as ações que procuram perturbar a liberdade humana.

Por conseguinte, Vladimir Propp (1895-1970), em Comicidade e riso (1992), ressalta que o riso é uma arma de combate e surge do reconhecimento de defeitos mesquinhos no outro, ou seja, “o riso é a punição que nos dá a natureza por um defeito qualquer oculto ao homem, defeito que se nos revela repentinamente" (PROPP, 1992, p. 44). O que se percebe ao longo da escritura do pensador é a tentativa de destacar diversos modos de rir, que tanto podem estar na condição desconjurada de rebaixar o outro, quanto se manifestam no viés comunicacional ou como forma de purgação e diversão, sem objetivos prévios, ou ainda, alcançarem o tom mais forte do escárnio. Para Propp (1992), algumas filosofias passaram a atribuir ao riso apenas um viés negativo, expondo que

O cômico é algo baixo, insignificante, infinitamente pequeno, material, é o corpo, é a letra, é a forma, é a falta de ideias, é a aparência em sua falta de correspondência, é a contradição, é o contraste, é o conflito, é a oposição ao sublime, ao elevado, ao ideal, ao espiritual, etc. (p. 20).

Propp (1992) destaca que essa perspectiva negativa está muito atrelada aos pensamentos de filósofos como Schopenhauer, Hegel e Visher; seus postulados nos conduzem a dois tipos de cômico, o alto e o baixo, destacando que a função depreciadora não percorre todo o ato do riso, mas é uma contrapartida de duas faces.

Finalizaremos essas incursões pelas teorias que discorrem sobre o riso com as considerações de três pensadores do século XIX, que, de alguma forma, em diálogo, constituem uma espécie de filosofia para as análises pretendidas neste estudo. O primeiro pensamento é o de Jean-Paul (1763-1825), pseudônimo de Johan Friedrich Richter. Para Minois, Jean Paul atribui universalidade aos atos risíveis, uma vez que a natureza humana é risível, sendo o mundo, em todas as suas instâncias, risível. Verena Alberti (1999) acrescenta aspecto importante para essa filosofia ao destacar que na ótica do pensador o riso não está plasmado no objeto risível, mas exatamente no sujeito que ri. Por sua vez, Alavarce ainda salienta que fator importante na teoria do filósofo está no fato de ele não opor o riso ao sério, mas reconhecer essa associação enquanto forma de conhecimento.

Charles Baudelaire (1821-1867) também disserta sobre a natureza do cômico, apresentando posições de relevo sobre o tema tratado. Seu discurso retoma os ideais da Idade Média, e apresenta como fruto de Satã. Voltando-se à afirmação que Jesus nunca riu, o escritor ressalta que o riso visa ao rebaixamento e não deve constar nas atitudes das pessoas sérias e de conhecimento. Sua visão demonstra, claramente, uma longa ligação 
com os discursos da Igreja Católica, que aboliu as manifestações risíveis de suas práticas por causa dos protestos que poderiam ser levantados frente às suas ações para com o povo. A ligação com o Diabo também está muito presente na concepção desse pensador, atribuindo ao riso a função diabólica da vingança, que é fruto da natureza humana. Em outras palavras, para o autor "[o] grotesco é um mergulho violento no mundo das aparências, um buraco no cenário que revela, de modo fulgurante, a derrisória e satânica realidade" (MINOIS, 2003, p. 535). Todavia, é importante salientar que Baudelaire reconhece a ação desbravadora de protesto e denúncia contra as mazelas sociais que marcam os tempos. E a diferença entre os pensamentos baudelairianos dos posicionamentos da Idade Média está na admissão de que o riso está ligado ao erro porque é humano. Em linhas gerais, a característica do homem e o que diferencia dos animais é sua condição risível. Também é essencial ressaltar que sua teorização dialoga com a de Jean Paul no que concerne ao ato do riso estar presente no sujeito, tornando-se inovadora a perspectiva de que não há nenhum tipo de riso inocente, ou mesmo sem intenção, conforme sublinha a pesquisadora Alavarce (2009).

Arthur Schopenhauer (1788-1860) também discute sobre a presença dos atos risíveis na vida do homem. Na perspectiva do filósofo, o riso é o que diferencia o homem do animal, sendo um ato necessário e inerente às pessoas. Schopenhauer reconhece que o riso é próprio do homem, que todas as pessoas riem, e o riso mais significativo é exatamente aquele que percebe a miséria humana e procura meios de denunciá-la. Em tal sentido, o cômico vem em resposta das incongruências visíveis entre os conhecimentos abstratos e intuitivos do ser.

Em seu livro O Mundo como vontade de representação (2005), Schopenhauer distingue duas formas de representação: a intuitiva ou concreta e a abstrata, que correspondem respectivamente ao conhecimento e à razão. "O riso se origina sempre e sem exceção da incongruência subitamente percebida entre um conceito e os objetos reais que foram por ele pensados em algum tipo de relação, sendo o riso ele mesmo exatamente a expressão de semelhante incongruência” (SCHOPENHAUER, 2005, p. 109). Em outras palavras, o riso vem da falta de aliança entre o concreto e o abstrato, que é uma união impossível, segundo postula o filósofo, uma vez que não há uma concretude entre realidade e pensamento, pois a razão é incapaz de alcançar a realidade.

Por fim, podemos fazer uma pequena articulação entre essas três proposições filosóficas finais. O riso é um elemento inerente ao ser humano, surgido a partir de uma incongruência entre pensamento e realidade, o que, por sua vez, é especificamente uma 
construção do sujeito, sempre derivado de uma intenção anterior. Em quadro amplo, é importante assinalar que a filosofia do século XIX conseguiu dar conta de uma noção plausível para o riso. Várias discussões anteriores, que muito estiveram atribuídas ao pensamento dominante, foram aportes para se clarear essa noção, uma vez que seus erros foram motivos para se continuar a perscrutar esse campo de pensamento.

Além das proposições de determinadas filosofias do riso, é importante ressaltar que houve sempre uma grande associação entre as formas de pensamento e as obras literárias. Muitas foram as estruturas literárias que passaram a acompanhar o modo de pensar da filosofia, trazendo para suas páginas a reprodução de discursos ora favoráveis, ora desfavoráveis para os modos de representar o riso. Mas a literatura pode usar a máscara de protesto, nem sempre vestir a da ideologia dominante, transformando-se em documento de denúncia às atitudes alienantes de uma sociedade.

\subsection{A constituição do gênero romance e o riso}

$O$ riso é uma posição estética determinada diante da realidade, mas intraduzível à linguagem da lógica, isto é, é um método de visão artística $e$ interpretação $d a$ realidade $e$, consequentemente, um método de construção da imagem artística, do sujeito e do gênero.

(BAKHTIN, 2010, p. 189)

O velho barbeiro Ivan Iacovlievitch acaba de jogar de uma ponte o nariz do major Kovalic dentro da água. O desprezível ato foi motivado pela forma inusitada de esse nariz aparecer dentro do pão em seu café da manhã. Ato insano esse, mais insano ainda é virarmos a esquina e encontrarmos um homem, o major Kovalic, com um lenço no rosto, dizendo estar correndo atrás de seu nariz, em suas roupas de autoridade ao perambular pela cidade. O que ora devemos pensar é quem se encontra em pior estado? O velho detentor do nariz até tentou explicar aos donos do jornal o triste acontecimento pelo qual andava passando, devido a sua importante situação diante das autoridades, mas não foi ouvido. Que naturalidade! Achava ele que todos teriam a mesma compreensão e veriam com tanta naturalidade o pequeno ato? O que nos resta diante desta pilhéria é o riso, não apenas ele, mas uma grande gargalhada.

Eis a ironia encontrada nesse pequeno relato da obra $O \mathrm{Nariz}$, do escritor russo Nicolái Gogol (1809-1852). Primeiramente, somos assaltados com a imagem de um nariz 
dentro de um pão; entretanto, o mais chocante é a presença desse órgão andando pelas ruas e a inusitada fotografia de seu dono correndo ao seu encalço para encontrá-lo. Se no limiar do enredo a ação choca, o desenrolar leva o leitor ao riso e faz com que se depare com uma espécie de discurso de bufonaria, que, anterior à reflexão que procura tecer, quer apenas provocar o riso. Esse estilo de representação literária marcou a Rússia do século XIX, sendo Gogol um de seus maiores expoentes, uma vez que os procedimentos estéticos apresentados pelo escritor perpassam acontecimentos fantásticos e servem como construções discursivas imaginárias, mas que brotaram de certa fonte de realidade. Mikhail Bakhtin (2014) ressalta que a obra de Gogol "é o fenômeno mais significativo da literatura cômica dos tempos modernos" (p. 429), ficando aqui o convite que a obra faz ao leitor para que ele ultrapasse seu dia a dia e passe a perscrutar outros espaços, tais como o da arte e do imaginário.

O estilo literário de Gogol integra uma grande tradição literária romanesca, composta por narrativas risíveis surgidas a partir da estilização e transformação dos gêneros clássicos. Mikhail Bakhtin (2010) salienta que o limiar da literatura era marcado pelos chamados gêneros elevados - a epopeia, a tragédia, a história e a retórica clássica; porém, conjuntamente a essas formas, havia sua contrapartida cômica, constituindo sempre um duplo. Mesmo relegada e deixada de lado, essa contrapartida cômica transgrediu as formas narrativas passando a superar o lado sério, sendo esse um dos motores que conduziu para o fim dos grandes gêneros. Superando e tensionando as formas anteriores, o romance surgiu, dentre outras razões, pelo tratamento especial atribuído ao herói. Basta apenas nos atermos à forma de representação da épica e sua grande exaltação ao herói e olharmos para o novo sujeito do discurso romanesco. Voltando à descrição inicial, nela observamos uma forma de rebaixamento velada à personagem principal da narrativa. Enquanto o sujeito da épica era exaltado, o personagem do romance moderno é ridicularizado e rebaixado, fazendo com que o leitor sorria perante sua representação imagética devastada e deslizante.

Com o advento do helenismo, as imagens dos heróis dos gêneros elevados são amplamente parodiadas e carnavalizadas, essas paródias criam uma espécie de território romanesco e a realidade em formação se transforma em matéria e alimento da prosa romanesca. (BAKHTIN, 2010, p.VIII).

Bakhtin problematiza a época de surgimento do romance e se contrapõe a algumas opiniões dissonantes quanto à época de surgimento do gênero. Enquanto autores como Ian Watt (2010) e Walter Benjamin (2012) ressaltam que o mesmo se deu a partir do 
século XVII, principalmente com as narrativas de Daniel Defoe e Miguel de Cervantes, Mikhail Bakhtin aponta que seu solo vinha sendo preparado desde o helenismo. A pesquisadora Marthe Robert (2007) propõe uma flexibilidade maior de pensamento quanto à sistematização de um período para o surgimento do gênero, pois, reconhecendo a vitalidade dos pensamentos que atribuíram ao limiar do romance às narrativas de Cervantes e Defoe, ela abriu espaço para uma possível participação de Rabelais também na galeria romanesca. Contudo, como constata Watt, as obras artísticas só passaram a carregar a denominação de romance no final do século XVIII.

George Lukács esclarece que existiam escrituras passadas (Antigo Oriente, Antiguidade, Idade Média) com características do romance; a forma romanesca, contudo, só ganhou estabilidade e se sobrepôs à epopeia com o nascimento das sociedades burguesas e sua separação em classes. "Todas as contradições específicas desta sociedade, bem como os aspectos específicos da arte burguesa, encontram sua expressão mais plena justamente no romance" (LUKÁCS, 1999, p. 87). Os escritores que participaram da transição e da procura de estabilização do gênero romanesco enquanto forma enunciativa da sociedade burguesa, nas palavras do teórico, tinham consciência do que estavam fazendo, da criação de uma nova estética; o romance, porém, só ganhou estabilidade plena no século XIX, sendo possível perceber nos séculos XVII e XVIII a tentativa de alguns escritores de usar a forma da epopeia para traduzir e dar conta do mundo, da vida e dos homens de seu tempo.

O romance, à luz dessas teorias, passa a ser visto como um gênero da vida cotidiana. Enquanto a épica é caracterizada pela grande exaltação do herói, pelo estilo discursivo acabado, pela projeção de figuras inalcançáveis e pelo retrato glorioso do passado, o romance participa da "criação" e transformação do mundo, como reflexo das forças históricas que influenciam os destinos dos homens. Essa nova forma narrativa participa do curso da vida, aproxima-se do cotidiano do homem comum, e passa, de alguma forma, a ser espelho da vida humana. É por essa aproximação com a realidade imediata, segundo Benjamin (2012), que o romance proporciona a reflexão sobre o presente, diferentemente da epopeia que não abre espaço mais para o questionamento social.

Ian Watt apresenta outra diferença entre o romance e os gêneros anteriores ao ressaltar que os clássicos se caracterizavam por possuírem enredos que retratavam a cultura de suas respectivas épocas, ao passo que as narrativas romanescas passavam a 
respaldar-se na individualidade do herói. Essa nova forma narrativa realista constituiu-se, especificamente, pela "soma das técnicas literárias através das quais o romance imita a vida seguindo os procedimentos adotados pelo realismo filosófico em sua tentativa de investigar e relatar a verdade" (WATT, 2010, p. 33). O que o pesquisador procura problematizar é uma maior aproximação dessa estilística com a vida humana, com o leitor. Para Bakhtin (2014),

A profecia é própria da epopeia, a predição é própria do romance. A profecia
épica se realiza totalmente nos limites do passado absoluto (se não em dada
epopeia, ao menos no limite da tradição que a envolve). Ela não diz respeito
ao leitor e ao seu tempo real. Já o romance quer profetizar os fatos, predizer e
influenciar o futuro real, o futuro do autor e dos leitores. O romance tem uma
problemática nova e específica; seus traços distintivos são a reinterpretação e
a reavaliação permanentes. O centro da dinâmica da percepção e da
justificativa do passado é transferido para o futuro. (p. 420).

Além da forma, autores como Benjamim e George Lukács apresentam ainda outros fatores que foram de suma importância para a evolução do gênero. A criação da imprensa, assim como o surgimento do capitalismo, nas palavras do pensador alemão, foram fatores primordiais que influenciaram na ascensão do romance, principalmente com a criação do livro impresso. Ele ainda acrescenta que o romance se divorciou, em grande medida, da oralidade, diferente da epopeia que mantinha grande ligação com as narrativas orais. À luz do pensamento de Lukács (2010), a ascensão do capitalismo e a necessidade das classes ascendentes se verem representadas foram atitudes pioneiras na criação do estilo romanesco, o que provocou um grande distanciamento da épica e seus relatos gloriosos de um passado; além do mais, essas novas narrativas não reproduziam o destino único de uma sociedade, mas, no máximo, de uma classe.

É possível considerar que tanto Bakhtin, quanto Ian Watt, assim como Walter Benjamin, estão de acordo quanto às diferenças que se perpetuaram entre épica e romance com relação à forma das escrituras que marcaram a distância entre a epopeia e o romance na história literária, mas existe um ponto em particular que diferenciou o olhar sobre a matéria romanesca, o qual levou Bakhtin a recuperar, no passado, os primeiros traços do gênero. Os estudos do pesquisador russo caminharam pelo viés da cultura e da carnavalização, sendo esse um dos principais pontos que dista a épica do romance. A carnavalização, para Bakhtin, está diretamente relacionada ao riso e ao retrato do cotidiano de uma época, contrário ao que se pregava nas narrativas épicas voltadas para os mitos antigos, distante do sujeito real e social. 
A categoria carnavalesca de Bakhtin, por exemplo, revela-se também na nossa contemporaneidade, atrelada à cultura de uma comunidade; no caso, no carnaval, festividade em que o sujeito se traveste, põe fantasias, reduzem-se os limites de classes sociais e as ruas ganham colorido, musicalidade, brilho e um só povo, mas principalmente fazemos uso da máscara enquanto disfarce para mudar de feição, para mostrar-nos outro. Essa imagem é essencial para nos remetermos aos grandes teatros, às personae constituídas e às autorrepresentações em praça pública. Sabemos que o carnaval também é espaço de festejos, de brincadeiras, constituindo um local uno de interação social, que não se restringe a uma classe específica, mas procura unir todos os povos em um único ritmo, em uma única festa. A imagem da festa retorna à Idade Média e ao Renascimento com François Rabelais que, segundo Bakhtin, é pioneiro no estilo literário risível, por indiciar a desestabilização da epopeia e o surgimento do romance.

O carnaval, para Bakhtin, também está vinculado à festa popular e aos festejos. Para o pensador, o carnaval não era uma imagem artística, mas o entre-lugar entre a arte e a vida, que não pressupõe a presença do palco, constituindo um espetáculo universal. "Os espectadores não assistem ao carnaval, eles o vivem, uma vez que o carnaval pela sua própria natureza existe para todo o povo" (BAKHTIN, 2013, p. 06). Os personagens principais dessa brincadeira eram os bufões e os bobos, imagens lendárias que provocavam o riso na população; em outras palavras, o carnaval está atrelado ao riso, à festa e à diversão, formalizando o que o teórico russo nomeou de cultura cômica popular. É importante salientar que "As festividades tiveram sempre um conteúdo essencial, um sentido profundo, exprimiram sempre uma concepção de mundo" (BAKHTIN, 2013, 07). É por via do desvendamento de uma concepção de mundo que se manifesta o principal sentido da carnavalização, que, como assinala Bakhtin, sempre surge em momentos de crise, em busca da renovação e da alternância da situação implementada.

A festa não teria nenhum sentido sem a presença do riso. $O$ aspecto cômico não estava conectado ao escárnio de um único sujeito à estrutura social posta, mas integrava o popular, era um riso universal que atingia a todos. "Esse riso é ambivalente: alegre e cheio de alvoroço, mas ao mesmo tempo burlador e sarcástico, nega e afirma, amortalha e ressuscita simultaneamente" (BAKHTIN, 2013, p. 10). O objetivo risível dizia algo sobre o mundo, expunha uma opinião, procurando a mudança da estrutura social do período; ao utilizar as imagens da morte e do renascimento, da coroação e, posteriormente, do destronamento, os festejantes almejavam a substituição daquela 
estrutura social. Mesmo que fosse por meio da brincadeira, da festa, percebemos uma maneira particular de protesto social, configurando um estilo uno de manifestar a insatisfação do povo; ao trazer na imagem carnavalesca a ideia de revolução.

Por conseguinte, quando a obra literária se apropriou das imagens carnavalescas para a sua constituição, carregou consigo a necessidade de mudança e de questionamento, apropriando-se da linguagem e dos ritos carnavalescos para representar uma concepção de mundo:

Essa literatura está imbuída da concepção carnavalesca do mundo; utilizava amplamente a linguagem das formas carnavalescas, desenvolvia-se ao abrigo das ousadias legitimadas pelo carnaval e, na maioria dos casos, estava fundamentalmente ligada aos festejos de tipo carnavalesco cuja parte literária costumava representar (BAKHTIN, 2013, p. 11).

Essa apropriação carnavalesca nas obras literárias, tratando da vida cotidiana de um povo e destacando o sujeito social fora dos elementos elevados, foi uma das principais diferenças que distanciou a epopeia do romance moderno. Mais uma vez, torna-se necessário frisar que a grande diferença entre esses gêneros está na introdução da carnavalização no âmbito literário, conforme Mikhail Bakhtin aponta. Para o filósofo, o romance surge a partir do momento em que as estórias literárias passaram a descrever o herói de forma rebaixada, como é o caso de narrativas como Diálogo dos Mortos e Gargântua e Pantagruel, em que os personagens da história são rebaixados, desnudados, apresentando características humanas, contrariamente ao pregado na épica. Para os pensadores que acreditavam que o romance surgiu a partir do realismo, ou seja, de narrativas que reproduziam a vida do homem comum, da classe burguesa em ascensão, as duas escrituras assinaladas acima não caberiam pelo jogo do imaginário presente em seus enredos, motivo que os afasta da vida cotidiana.

Mas é aqui que se abre uma grande incógnita: se essas duas histórias, exemplos de uma grande seara de narrativas esquecidas, não cabem no estilo épico e não servem ao romance, a que tipo de gênero elas pertencem? Para Bakhtin, o gênero sério-cômico caminhava lado a lado com as grandes epopeias e se tornou o responsável pela desestabilização dos gêneros consolidados. O pesquisador ressalta que essas narrativas ainda não possuíam a estética do romance, pois estavam marcadas por lendas e mitos, mas traziam em suas páginas as características humanas doadas aos heróis dos mitos, além da criticidade. 
Em Problemas da Poética de Dostoiévski (2010), o russo aponta que a Antiguidade Clássica e o helenismo serviram de palco para o surgimento de diversos gêneros, cada um com suas peculiaridades, mas que guardavam aspectos comuns, formando um campo todo especial na literatura, que passou a ser denominado sériocômico. Dentro dessa nova categorização, instalaram-se formas literárias como os “mimos de Sófron, o diálogo de Sócrates, a vasta literatura dos Simpósios, a primeira Memorialística, os panfletos, toda a poesia bucólica, a sátira menipéia”, entre outras. Os novos olhares para essas manifestações de literaturas insurgentes "percebiam nitidamente a originalidade essencial desse campo e o colocavam em oposição aos gêneros sérios, como a epopeia, a tragédia, a história, a retórica clássica” (BAKHTIN, 2010, p. 121).

Essa dualidade literária sobre a máscara de diversos gêneros do carnaval caminhava com a dualidade da vida, do cotidiano, sempre mesclando o sério e o cômico, o oficial e o não oficial; para Bakhtin (2010), em referência à Idade Média, "pareciam ter construído, ao lado do mundo oficial, um segundo mundo e uma segunda vida aos quais os homens da Idade Média pertenciam em maior ou menor proporção, e nos quais eles viviam em ocasiões determinadas" (p. 05). Devido à grande proximidade com o folclore carnavalesco, esses gêneros eram dotados de uma profunda "cosmovisão carnavalesca", sendo, em muitos casos, surgidos de relações diretas com a oralidade. Para Bakhtin (2010),

\begin{abstract}
A cosmovisão carnavalesca, que penetra totalmente esses gêneros, determinalhes as particularidades fundamentais e coloca-lhes a imagem e a palavra numa relação especial com a realidade. É bem verdade que em todos os gêneros do sério-cômico há também um forte elemento retórico, mas este muda essencialmente no clima de alegre relatividade da cosmovisão carnavalesca: debilitam-se a sua seriedade retórica unilateral, a racionalidade, a univocidade e o dogmatismo. (p. 122)
\end{abstract}

Para o pesquisador russo, os gêneros instalados no sério-cômico possuíam três características principais voltadas para o tratamento atribuído à realidade. A primeira é a atualização do cotidiano: aquilo que na literatura antiga estava no terreno do mito e das lendas retratando o passado, esses novos gêneros aproximaram do cotidiano, trouxeram para a realidade do sujeito. Northrop Frye (1957) destaca que "no período da estória romanesca, o poeta, como o herói correspondente, tornou-se um ser humano e o deus se retirou para o céu" (p. 62). Este pesquisador, assim como aquele, percebeu a grande influência da esfera social para a composição das narrativas cômicas, fazendo dos heróis 
das estórias romanescas peças fundamentais para essa aproximação com o real, com o presente inacabado.

A segunda característica apontada por Bakhtin, em diálogo com a anterior, encontra-se no desapego das lendas em nome da criação livre e da experiência imediata. As lendas no sério-cômico passam a ser parodiadas e não há mais um apego às verdades pregadas nesses mitos; o que interessa aos autores é a criação e a aproximação com a cultura e os costumes de seu tempo. Em outras palavras: "Trata-se de uma verdadeira reviravolta na história da imagem literária” (BAKHTIN, 2010, p. 123).

A terceira peculiaridade do campo em estudo é a "pluralidade de estilos e a variedade de vozes de todos esses gêneros." Sua estilística diferencia totalmente das dos gêneros consolidados, fazendo uma grande mistura do "sublime e do vulgar, do sério e do cômico" (BAKHTIN, 2010, p. 123), além de conjugar várias formas literárias em sua constituição, como paródia e cartas, e misturar prosa e verso.

Essas são as três características apontadas por Mikhail Bakhtin para diferenciar o campo do sério-cômico dos gêneros antigos, as quais, por sua vez, foram os principais elementos que caracterizaram o romance europeu e as narrativas que passaram a surgir posteriormente. Assim, existiram dois gêneros que se sobrepuseram aos demais na perspectiva do pensador russo, tornando-se cruciais para a evolução e diferenciação das narrativas passadas e seu caminhar para o que se passou a ser romance: os diálogos socráticos e a sátira menipeia.

Prosseguiremos nossas considerações procurando detalhar o surgimento dos diálogos socráticos. É importante assinalar que sua fonte não estava apenas nas retóricas antigas, mas fazia um passeio pelos gêneros carnavalescos, tendo como raiz as fontes orais. O nome deriva de Sócrates, formando-se a partir de memórias das palestras do pensador reconstruídas em formas narrativas. O caráter memorialístico que prevalecia no início com o tempo foi se esvaindo, ficando especificamente a necessidade de uma revelação da verdade, como foi possível perceber, na perspectiva bakhtiniana, em escrituras como de Platão e Xenofonte.

Uma das primeiras características que demarcou o gênero foi sua natureza dialógica, espaço em que a verdade não se encontrava em um único sujeito, mas integrava um campo de pensamento, discutindo-se sobre determinado tema e procurando encontrar fios que o ligassem à determinada verdade. No limiar, estabeleciam-se grandes relações 
com o carnavalesco, mas sua evolução o encaminhou para a busca de verdades prontas, criando, nesse sentido, o que hoje conhecemos como filosofia. Em outros termos, perdeuse o caráter da praça pública, dos confrontos diretos, em nome de verdades acabadas. Por sua vez, os debatedores que marcavam essas arenas discursivas eram reconhecidos enquanto ideólogos; tendo como primeiro representante a própria figura de Sócrates, debatiam e discutiam as questões levantadas em busca de determinadas verdades, marcadas por provocações de ambos os lados, em nome da comprovação de uma ideia. Para Bakhtin, é aqui a entrada do herói-ideólogo nas narrativas europeias.

Posterior aos diálogos socráticos, surgiu a sátira menipeia. A diferença que se estabeleceu entre os dois gêneros foi o aumento dos elementos cômicos nesta última, assim como o caráter memorialístico que resguardava no anterior não a integrava mais, dando-lhe total liberdade de expressão. "É possível que em toda a literatura universal não encontremos um gênero mais livre pela invenção e a fantasia do que a menipeia" (BAKHTIN, 2010, p. 130). Igualmente ao diálogo socrático, o herói da menipeia estava em busca da experimentação de uma ideia; as diversas aventuras passadas, as peripécias sofridas, todas deram lugar a esse objetivo final, do ideólogo em busca da comprovação de sua ideia. "Podemos dizer que o conteúdo da menipeia é constituído pelas aventuras da ideia ou da vontade no mundo, seja na Terra, no inferno ou no Olimpo" (BAKHTIN, 2010, p. 130).

Percebemos, então, que estão presentes no gênero elementos fantásticos e simbólicos que elevam ao extremo as questões mundanas, assim como fez nascer um novo estilo de herói, embebido pela loucura e toda uma outra série de elementos voltados para os estados psicológicos do sujeito. Esta última é um traço marcante que diferenciará a personagem romanesca da presente na épica, que estava sempre atrelada aos fatores elevados do gênero humano; o novo herói romanesco não foge aos escândalos, assim como brinca com o jogo do contraste e das oposições. A organicidade da menipeia acopla vários outros gêneros, como novelas, cartas, discursos oratórios e solilóquios, oferecendo múltiplas possibilidades de constituição, possibilitando a atualização e transformação dos grandes gêneros. Por sua vez, é importante ressaltar que, enquanto os diálogos socráticos tiveram poucos anos de vida, as menipeias permanecem vivas na atualidade. Esse gênero é o que carrega maior aproximação com os rituais de carnavalização, devido à proximidade com a realidade imediata e a alegoria social tecida. Caracterizado por seu caráter contestador, debruça sua crítica, principalmente, sobre a épica e a trágica, por ver 
nessas representações literárias anteriores a busca de uma unidade, de um pensamento único, contrário ao movimento carnavalizado próprio dos gêneros do sério-cômico.

Finalizamos nossas incursões sobre os gêneros literários apontando o campo do sério-cômico como um dos principais responsáveis pelo fim da epopeia enquanto gênero consolidado, e a carnavalização como um dos ingredientes fundamentais do romance moderno, aliando à vida as produções artísticas em nome do retrato do cotidiano do homem comum, da equalização dos discursos, constituindo uma cultura cômica popular. A característica carnavalizada dos heróis que marcavam o sério-cômico passou a percorrer a forma e o conteúdo das histórias romanescas, deixando de falar de mitos e lendas e passando a retratar o cotidiano do homem comum; o surgimento e a ascensão da burguesia e do capitalismo que se fundia com os novos anseios do sujeito social - a necessidade do ter, do possuir, a ganância, as disputas sociais, típicas do mundo capitalista - foram as principais críticas que permearam as histórias romanescas e que as colocaram no terreno do riso; fazendo dele uma das mais importantes fontes de protesto ao sistema social. A literatura, em outros termos, passou a retratar essa realidade em suas ficções, tornando-se uma grande fonte de protesto contra as mazelas que atravessaram seu tempo.

\subsection{Por uma literatura do riso: alguns causos literários}

É melhor escrever sobre risos que sobre lágrimas, pois o riso é o apanágio do homem.

François Rabelais

Reza a história das humanidades que há muitos anos, na Antiguidade Clássica, grupos de festejantes saíam às ruas para celebrar a vitalidade de um deus, Dioniso, deus do vinho e da embriaguez, em praça pública. Os cultos realizados em homenagem a Dioniso denunciam, na história grega, a presença do riso festivo grupal; era um riso em busca da proteção divina, sem motivos que direcionassem à derrisão, mas apresentavam elementos morais, lições para a vida dos festejantes. Com efeito, existiam muitas formas de manifestações, como as dionisíacas, as bacanais, as leneanas, entre outras, sempre de cunho religioso. Dentre os festejantes, junto ao povo, havia certas figuras importantes para a composição do espetáculo, os sátiros, personagens com falos exacerbados que 
levavam a alegria e o riso às ruas. Nesse sentido, o estilo risível apresentado por essas pessoas era imbuído de caráter animalesco, o que resultava no abalamento do sério. Segundo Minois, o riso dionisíaco preside

\begin{abstract}
"ao mesmo tempo a tragédia e o drama satírico, ele [Dioniso] é o mais turvo dos deuses: está atrás do vinho e da embriaguez, mas também atrás da natureza selvagem, da possessão extática, da dança, da máscara, do disfarce, da iniciação mística." (MINOIS, 2003, p. 37).
\end{abstract}

Pode-se destacar a presença do rito carnavalizado desde o limiar da história da humanidade, aliando o grotesco e o irônico, mas não deixando de apontar o elemento dramático por trás dessas representações. As máscaras e a dança, entre outras características, foram apropriadas pelos ritos dramáticos, podendo ser encontradas em uma variedade de peças teatrais posteriores. Perante tais circunstâncias, podemos perceber que houve na história da humanidade momentos em que o sério e o cômico prevaleciam ao mesmo tempo em um espaço uno e possuíam o mesmo prestígio. Essa estabilidade entre essas duas percepções de mundo foi quebrada, na perspectiva bakhtiniana, com o estabelecimento do regime de classes e a constituição do Estado.

A epopeia foi um estilo clássico de literatura totalmente voltado para o sério, entretanto, suas linhas ainda guardaram espaço para o riso, como pode ser visto nas narrativas Homéricas Ilíada e Odisseia. Mesmo que suas formas enunciativas estivessem ligadas a uma espécie de teor cômico agressivo, justificado pela desforra dos deuses sobre os humanos, não se pode deixar de acentuar a propensão risível nessas narrativas, principalmente sob a figura de deuses rindo de humanos. A cultura cômica popular, o retrato carnavalizado pregado pelos mitos gregos tornaram impossível se escrever qualquer tipo de vida sem que, pelo menos em poucos momentos, surgisse a presença do cômico. Vale lembrar que, na Antiguidade, o riso não era uma forma depreciativa de visão do mundo, mas uma tentativa alegre de superar as barreiras da vida.

$\mathrm{Na}$ Odisseia, quando Ulisses bate em Íons, os deuses riem do ato e do sofrimento humano. George Minois (2003) destaca que o riso grego estava aliado à morte e ao sentido de punição, reafirmando a vitória sobre o aparente inimigo: “O riso nos mitos gregos, só é verdadeiramente alegre para os deuses. Nos homens nunca é alegria pura: a morte sempre está por perto, e essa intuição do nada, sobre o qual todos estamos suspensos, contamina o riso" (p. 27). Desse modo, o riso dessa época estava marcado pela compreensão dos espectadores ao sujeito do riso, marginalizando o objeto risível, excluindo-o, agredindo e humilhando, uma vez que o representado é a necessidade da 
união grupal por meio da exclusão do outro, prevalecendo no humano a aceitação do destino imposto pelos deuses. É visível como a narrativa dialoga com o pensamento aristotélico em relação ao humano, uma vez que a comédia retrata o homem em sua natureza imediata.

Posteriormente às escrituras de Homero, deparamo-nos com a obra Diálogo dos Mortos, de Luciano de Samósata (125-180). Essa narrativa abre com a seguinte cena: "Menipo, exorta-te Diógenes, se riste bastante das coisas da terra, que vás lá embaixo, para rires muito mais" (LUCIANO, 1998, p. 15). A obra de Luciano é uma paródia das epopeias homéricas Ilíada e Odisseia, apresentando como objetivo principal rebaixar, por meio do riso satírico, as personagens gregas e os valores humanos. É importante assinalar que o espaço escolhido para a narração discursiva é o da morte, a chegada das pessoas ao Hades, manifestando o desprezo pela vida. A natureza humana nessa narrativa contrasta com o mito, o fato irreal exemplificado pela descida ao inferno, parodiando a vida e apontando os defeitos humanos.

O teatro foi um dos principais palcos de representação do riso, constantemente misturando tragédia e comédia, na tentativa de mostrar as várias faces da natureza humana e social. Aristófanes (445 a.C. - 389 a.C.) foi o grande representante da independência do riso na sociedade grega. Seu teatro fez um passeio pelas várias faces da sociedade, desde a política, percorrendo a filosofia e alcançando os próprios deuses, apresentando um riso agressivo e cômico. Tudo se tornou elemento cômico, a vida passara a ser cômica, na iminente procura de atingir um membro da sociedade ou as práticas burlescas de um povo. Nesse sentido "o riso devastador de Aristófanes não deixa nada de pé; Sagrado e profano tombam igualmente no ridículo e no obsceno, por mais cru que ele seja” (MINOIS, 2003, p. 39). O teatrólogo integrava o que passou a ser chamado de Comédia Nova; suas peças eram marcadas por uma forte crítica social, atingindo, principalmente, a política de seu tempo.

Umas das principais peças de Aristófanes é As rãs, forma de manifestação artística que visava a repensar o discurso do outro de forma crítica. Quando a narrativa apresenta duas formas diversas de pensar a arte literária, procura, também, tomar posição com relação a uma dessas formas de olhar artístico, por meio do riso paródico. Nesse sentido, o que o leitor vai encontrar nas páginas da escritura dramática é a paródia de dois tipos de discurso em que, no final, se sobressai um. O retirar do mundo dos mortos, ou o estar nesse mundo, à semelhança da narrativa de Luciano, é uma manifestação de discurso crítico, de rebaixamento dessas figuras. Mas o que mais chama a atenção nesse plano de 
enunciação é a linguagem risível, forma burlesca de atacar e criticar, mas, ao mesmo tempo, pensar de forma divertida essas visões dos fatos artísticos.

François Rabelais (1494-1553) foi uma figura inusitada para seu tempo. As narrativas rabelaisianas são compostas à luz de discursos que põem em choque tanto a figura do bobo, personagem zombeteiro, quanto a presença do bufão, o sujeito sofredor dos escárnios do bobo. Para Auerbach (2011) “O real cotidiano está engastado na fantasia mais inverossímil; a farsa mais grosseira está cheia de erudição, e as elucidações filosófico-morais brotam de palavras e de histórias obscenas" (p. 243). A escritura rabelaisiana foi um escândalo para seu tempo, trazendo vozes narrativas que rebaixam o sujeito a seu último estamento; o romancista apropriou-se dos artifícios carnavalescos, como o aumento das proporções das ações narradas para provocar o estranhamento; utilizou-se de uma estilística que enunciava a praça pública, que expunha, ridicularizava, desvendava o privado, desmascarando o sujeito. "Penso que vários que são hoje imperadores, reis, duques, príncipes e papas na terra, descenderam de coletores de restos e de lixo. E, ao revés, há mendigos, sofredores e miseráveis, que descendem em linha reta de grandes reis e imperadores" (RABELAIS, 1991, p. 38). A inversão de papéis enuncia a carnavalização e o rebaixamento da personagem romanesca, por via da sátira e da tentativa de mudança das ações sociais.

O romancista passou a ser considerado o grande tradutor do riso de sua época; escritor de obras de grande representação para a literatura francesa, Gargântua e Pantagruel (1532), sua escritura foi concebida em momentos de maior repressão da Igreja Católica ao riso, demonstrando um ato de protesto contra essa manifestação social e de poder da Igreja contra a sociedade e a arte. O riso traçado em suas páginas narrativas procurava mostrar dois lados, configurando-se pelas constantes inversões realizadas, e o rebaixamento das figuras importantes de seu tempo, quebrando as normas vigentes da atual sociedade. Até a representação do diabo perdeu seu caráter maligno e passou a ser encarada de forma boa, contrária à representação dos deuses. Nesse sentido, "O riso rabelesiano é mais vivamente sentido porque, atrás de sua erudição arcaica, é muito moderno. As alusões geográficas e pessoais são claras, e a sátira político-religiosa aflora nitidamente" (MINOIS, 2003, p. 277). É sempre importante assinalar a natureza grotesca e contestatória da obra desse romancista às situações sociais de sua época.

Mikhail Bakhtin (2014) ressalta que "Rabelais foi o grande porta-voz do riso carnavalesco popular na literatura mundial. Sua obra permite-nos penetrar na natureza complexa e profunda desse riso" (p. 11). O que se procura apontar, com essa assertiva, é 
a natureza de apropriação dos modos antigos de riso pelo escritor francês e uma possível estilização dessas formas anteriores, reconfigurando um novo estilo narrativo, que faz do autor um grande conhecedor das tradições do riso anterior, mas que inaugurou um espaço de representação romanesca através do riso alegre, festeiro, mas, ao mesmo tempo, grotesco, o qual faz uma mistura linguística e corporal, aliados aos grandes banquetes e ao rebaixamento do grande sujeito da história romanesca. Para Erich Auerbach (2012):

\footnotetext{
Os elementos fortemente realistas ou obscenos tornam-se, pelo tempo do discurso e das alusões que se seguem umas às outras um redemoinho espiritual; as tempestuosas gargalhadas que tais passagens ocasionam estremecem todos os conceitos da ordem costumeira daquele tempo. (p. 238).
}

Não é mais o riso grotesco e satírico vivenciado nas narrativas de Luciano, mas prevalece o tom de alegria, do carnaval, da festa popular. A presença dos elementos corporais serve como aproximador, por meio da linguagem, do ambiente particular, intentando com isto, aproximar os homens.

Tantas glórias foram exaltadas à figura de Rabelais, e Dom Quixote de La Mancha (1605), onde se encontra? A narrativa de Miguel de Cervantes (1547-1616) é vista pela crítica literária como uma das maiores narrativas presentes na literatura ocidental. $\mathrm{O}$ prólogo abre com a seguinte cena: "Desocupado leitor: sem juramento meu embora, poderás acreditar que eu gostaria que este livro, como filho da razão, fosse o mais formoso, o mais primoroso e o mais judicioso e agudo que se pudesse imaginar" (CERVANTES, 2010, p. 24).

Trata-se de uma narrativa irônica, brincadeira com a figura do leitor, palavras ferinas que dizem sem dizer, que trazem em suas linhas sentidos outros, metáforas, alegorias, mas sempre por meio do riso, das situações cômicas, dos costumes invertidos e do estranhamento do outro para aquilo que foi pronunciado. A narrativa do cavaleiro que andava atrás de aventuras em uma época em que não havia mais cavalaria, loucura provocada pelo enorme número de leituras de romances cavaleirescos, traz em suas páginas uma grande ironia ao próprio estilo romanesco, levando o leitor, como construtor essencial do riso às de gargalhadas a cada página lida. "Num vilarejo da Mancha, de cujo nome não quero lembrar-me, não há muito tempo vivia um fidalgo dos de lança em lanceiro, adarga antiga, rocim magro e cão corredor" (CERVANTES, 2010, p. 51).

Sobressai ao longo da narrativa a ironia constante dos narradores à personagem, fazendo da construção do outro um grande espaço de riso e zombaria; com o emprego de uma estilística rebuscada que sempre está insinuando o contrário do dito, assim como o 
uso da linguagem de cavalaria, que não predominava no momento, leva os outros da narrativa à gargalhada. Auerbach (2011) desenha as duas figuras principais da escritura, Dom Quixote e Sancho Pança, e seus possíveis contrastes, a partir de um modelo que se perpetuava na história das narrativas cômicas:

Duas figuras que aparecem simultaneamente, em mútuo contraste, cômicas ou semicômicas, este é um motivo muito antigo que ainda hoje tem sua eficácia em toda parte: na piada, na caricatura, no circo ou no filme: o magro alto e o gordo baixinho, o astuto e o tolo, o senhor e o criado, o homem distinto e culto e o camponês ingênuo e outras combinações ou variantes que possa haver em diferentes países e culturas. O que Cervantes fez disso é maravilhoso e único. (p. 316)

Além das características que atravessam a história das narrativas risíveis, vemos nas palavras de Auerbach a exaltação da criação de Cervantes, narrativa que representava uma grande ironia aos modelos literários ultrapassados da época - A figura da personagem sobre a máscara do bobo pode ser vista apenas como uma alegoria da inexistência dos romances de cavalaria do período e a necessidade de mudança no campo literário.

O Homem que ri (1869), narrativa de Victor Hugo (1802-1885), celebra uma das maiores investidas filosóficas do riso ao trazer a imagem devastada da personagem com a face congelada, aparentemente em uma constância de riso, mas que, ao contrário, vive um grande drama. É importante frisar nesse momento que estamos iniciando o século XIX, momento em que as filosofias enunciavam, como vimos anteriormente, uma nova forma de concepção risível, totalmente voltada para o protesto e o desnudamento das estruturas sociais, muito por meio da sátira ou do humor grotesco. Essas características que selavam as filosofias se tornaram palco para escrituras romanescas, afloradas pela escola realista que passa a surgir a partir de meados do mesmo século, produzindo um tipo especial de literatura, totalmente direcionada ao riso trágico. Minois (2003) aponta que:

o riso hugoano quase sempre tem um eco sinistro e avermelhado, como no inferno. Ele testemunha o riso lúbrico, que rebaixa ao nível do animal, fazendo com que o velho fauno ria; testemunha os risos de desprezo que acabrunham a feiura" (p. 541).

Em O homem que ri, o leitor se surpreende desde o nome das personagens principais da escritura, em que Homo é o lobo e Ursus é o homem; assim como as descrições de ambas levam o humano com característica de animal e o animal com as características humanas. "Ursus era o homem, Homo era um lobo. Seus temperamentos combinavam. O homem tinha batizado o lobo. Provavelmente escolhera também seu 
próprio nome; tendo achado Ursus bom para si mesmo, achara Homo bom para o animal" (HUGO, 2014, p. 39). Ao longo do romance é possível perceber o desajuste da personagem principal ao mundo em que vive, apresentando o caráter monstruoso que o separa da sociedade que habita, além de seus hábitos inversos. Sua caracterização demonstra o próprio riso congelado pela deformação da face, tornando-se motivo de riso dos outros por causa de sua fealdade. Nesse sentido, enveredamos com a personagem por uma sociedade grotesca e, ao mesmo tempo, trágica, triste, constituindo o trágico-cômico da narrativa. $\mathrm{O}$ contraste que a narrativa enuncia provoca o riso, a crítica da população à figura do protagonista e a situação monstruosa que passa a figurar para aquele povo. Dessa forma, o riso surge como espaço de crítica social, de rebaixamento, apontando as misérias humanas por meio da realidade de um personagem com modos grotescos, em que sua própria imagem se torna bizarra para a realidade social do período.

Em uma praça, Catierina Ivanóvna e seus dois filhos cantam para as pessoas que passam. A cantiga é interrompida pela expressividade emocional da mulher que começa a gritar suas desgraças em praça pública; posteriormente, suplica aos filhos para continuarem a música, pois precisam arrecadar dinheiro para a sobrevivência. $\mathrm{O}$ marido, que sempre estava bêbado, havia morrido, e a trágica história obrigava essa mulher, com seus dois filhos, a passar por tal aflitivo ato. A cena trágica, o retrato carnavalizado, tendo como palco a praça pública, foi montado e, ao mesmo tempo que estamos vivenciando o espetáculo, somos instigados ao riso e à dor. Esse é apenas um pequeno fio narrativo de Crime e Castigo (1866), um dos maiores romances do escritor russo Fiodor Dostoiévski (1821-1881).

O riso que transparece nas obras do romancista está aliado ao trágico, ao escândalo, à própria morte. Desde as manifestações de loucura do Homem do Subsolo, em Memórias do Subsolo, à representação em praça pública, presente em Crime e Castigo, podem ser levantadas as formas desse realismo trágico e monstruoso, com riso sombrio. Segundo Bakhtin, “A carnavalização permite a Dostoiévski ver e mostrar momentos de caráter e do comportamento das pessoas que não poderiam revelar-se no curso normal da vida" (BAKHTIN, 2010, p. 188). "Bobók" (1873), um dos principais contos do escritor representa o auge do riso e da zombaria das narrativas do romancista russo. Desde o cenário percorrido, o cemitério, até as conversas dos mortos, formas enunciativas fantásticas, somos assaltados por um grande riso, que em sua origem tem precedências zombeteiras. A conversa que se estabelece no túmulo aponta a equalização 
discursiva, uma vez que se propõe a destacar que, após a morte, todos os homens são iguais, não restando nada de bem adquirido na terra que possa interferir. Nesse sentido, salienta-se, nesse momento, a presença da morte enquanto unificadora, uma vez que perante ela, todos são iguais, todos terão o mesmo fim.

Nessas paragens, "o inferno carnavalizado de Bobók está internamente em profunda consonância com as cenas de escândalo e catástrofes tão essencialmente importantes em todas as obras de Dostoiévski" (BAKHTIN, 2010, p. 166). Em linhas gerais, o autor buscava representar, por meio do discurso carnavalizado, as contradições sociais que culminavam na sociedade russa, o viés psicológico em destaque, levava o leitor a confrontar o retrato da dor com o discurso cômico-dramático, vidas instigadas e subtraídas pelas imposições sociais.

A fim de ilustrarmos mais uma narrativa, sigamos Akaki Akakievcht ao sair para seu trabalho e ao retornar dele, consultando a possibilidade de possuir um novo capote e a trágica morte dessa personagem por sucumbir ao frio. O narrador faz o seguinte retrato:

\footnotetext{
Pois bem, num departamento trabalhava um funcionário. Não se pode dizer que esse funcionário fosse lá essas coisas: baixote, tinha algumas marcas de bexiga no rosto, era um pouco arruivado, com miopia um pouco pronunciada, uma pequena calvície na fronte, ambas as faces enrugadas e o semblante com uma daquelas cores a que se pode chamar de hemorroidais ... mas, o que se há de fazer?! A culpa é do clima de Petersburgo. (GOGOL, 2010, p. 07)
}

Essa pequena fotografia pertence à narrativa $O$ Capote (1842), de Nicolai Gogol, escritura que retrata a vida de um pobre diabo que ganhava simplesmente a quantia necessária para abarcar as pequenas necessidades. Sem nenhum tipo de ambição, a personagem chega até a recusar um emprego melhor. Mas como a vida não falha com os seus, o velho capote de todos os dias e todas as costuras se aposentou, não havendo mais formas de conserto, trazendo a primeira consequência social. Akáki teve de gastar o pouco que tinha e que não tinha para a compra. Mas o elemento trágico, que vem sendo desenhado de forma cômica, rebaixando e ridicularizando as atitudes mesquinhas da personagem, termina com o roubo do capote e a morte do protagonista.

Gogol foi um grande cultor do riso de sua época. Unindo o cômico com o trágico e o fantástico, o escritor fotografou várias realidades das miserabilidades que marcavam a sociedade russa. "O satírico que ri não é alegre. No fim, ele é carrancudo e sombrio. Mas o riso de Gógol é vitorioso em tudo. De fato, ele criou o seu próprio gênero e catarse da trivialidade" (BAKHTIN, 2014, p. 439). A descrição cômica dos fatos que acompanham a vida da personagem são os elementos que conduzem ao riso, que, mesmo 
retratando fatos tristes, o faz por meio da comicidade. O rebaixamento do herói é visível, e a mesquinharia que percorre as páginas de $O$ Capote é que leva o leitor a rir de sua imagem. É importante frisar que nas narrativas do escritor russo o elemento cômico, aliado ao fantástico, supera a natureza trágica narrativa, restando ao leitor apenas o riso perante histórias tecidas. Não é estranho que a figura do narrador sirva sempre como a condutora à ridicularização e à zombaria, assim como pode ser visto em Cervantes.

O realismo na literatura, a partir deste ponto da investigação, é nosso ponto de parada e avaliação ${ }^{3}$. No entanto, o percurso pelas produções literárias anteriormente avaliadas não foi apenas de caráter didático e informativo, porque tais produções tiveram impacto profundo na escritura do autor - Lima Barreto - que, por agora, passará a ser objeto de análise. Repassamos uma espécie de tradição literária que atravessa épocas e espaços, reconfigurando, a cada nova manifestação, um estilo específico de representação risível-literária. É importante perceber, dentro dessa passagem por algumas obras importantes para a história da literatura mundial, que mesmo as que são fruto de enredos trágicos têm em suas linhas cenas risíveis, mudando, de alguma forma, o olhar do leitor para a escritura. Ao pensarmos no trágico como dominante, às vezes, não percebemos que por trás das atitudes dos heróis está a pueril galhofa, a pilhéria do narrador sobre a personagem descrita. Isso se justifica por colocar a obra literária no terreno do humano, salientando a indissociabilidade entre a natureza humana e o riso.

\subsection{E os séculos XX e XXI}

Se o século XIX foi marcado pelo riso sério, visando ao encontro com novos caminhos, o século XX não estaria indiferente às práticas sociais. Entretanto, frente a todas essas formas de riso anteriores que delinearam várias facetas perante os movimentos sociais culminantes, Minois (2003) ressalta que "Esse século Morreu” (p. 553). Quando o pesquisador faz essa afirmação parece salientar a grande força risível que se instaurou nessa nova época. Ela não apresentava posturas negativas, mas torna-se obrigatória e inerente à sociedade do espetáculo. Entretanto, é importante assinalar que o riso nasce como fruto das incertezas que surgem do desconhecimento da direção para qual está caminhando o mundo. Não é, necessariamente, um riso de alegria, podendo ser, de alguma

\footnotetext{
${ }^{3}$ O Realismo e parte da literatura romântica ressaltarão o riso como crítica social, ridicularizando o homem vil, o covarde, o mesquinho e outros tipos sociais de conduta reprovável.
} 
forma, originário do medo. O desprendimento das ações sociais, aliadas às catástrofes, passou a virar motivo de brincadeira para as pessoas, tudo é transformado em diversão, daí se encontra o significado da qualificação atribuída por Minois. Para o pesquisador, “o riso do século XX é humanista. É um riso de humor, de compaixão e, ao mesmo tempo, de desforra, diante dos reveses acumulados pela humanidade ao longo do século e das batalhas perdidas contra a idiotia, contra a maldade e contra o destino" (MINOIS, 2003, p. 558). Os acontecimentos são tão difíceis que o riso se torna meio de escape para a sobrevivência mundana, modo de fugir dos problemas e da correria do dia a dia. Minois (2003) aponta que até a Igreja, grande contestadora dos padrões risíveis ao longo dos séculos, procurou meios de reconciliação, remexendo na própria história e visando a representar um Deus risonho para a humanidade.

Frente a essa variedade de perspectivas que nos colocam no espaço risível é importante apontar a loquacidade de olhares e mudanças de pontos de vista que foram se formando ao longo dos tempos. Uma época se apropria das manifestações de riso da anterior para representar diferentemente seu tempo, e esse jogo de mudanças e de retornos ao passado foi constituindo um longo processo social e filosófico das culturas, as quais nunca deixam de rememorar as práticas passadas para, a partir delas, construírem suas próprias visões de mundo. Além disso, podemos ressaltar que o riso se tornou filosofia e tratado dos costumes de um tempo devido aos vários debates que giram em torno de sua representação e construção junto às culturas e os costumes de um povo.

Por sua vez, se iniciamos nossos relatos pensando a recusa ao riso por meio das filosofias platônicas, pudemos alcançar uma variedade de pontos de vista que foram se formando ao longo dos séculos. As festas em homenagem a Dioniso nos apresentaram um riso festivo e alegre com elementos de moralidade. Mas a literatura se tornou arena para a representação de toda a variedade de riso ao longo dos séculos. Iniciando pela literatura de Homero com o riso ligado aos deuses e à morte humana, alcançamos Luciano, construtor de uma visão contestatória e satírica do riso. Rabelais, por meio do jogo das inversões, destronou a sociedade francesa da Idade Média, fazendo dela um grande mundo carnavalizado e risível. Fomos ao encontro das representações de Dostoiévski e alcançamos Hugo; a tradução do riso, contudo, não se pautou apenas nessas poucas vozes responsivas, mas contaminou toda a história da literatura Ocidental. A filosofia também não cessou seus discursos de representação, fazendo reinar no século XIX uma seara de perspectivas sobre as formas risíveis. O riso dessa época era de protesto e visava questionar as ações sociais dos tempos. 
Num panorama geral, a visão de riso que temos hoje foi fruto da união desses vários modos de conceber o literário, trazendo para o centro da vida um riso muito marcado pelo relato irônico-discursivo. Os acontecimentos sociais passaram a ser vistos e reproduzidos por meio da gargalhada e da paródia. Os grandes programas de humor têm como conteúdo relatos distorcidos da vida, valores alterados e subversivos. Percebemos, na contracorrente, que não temos um riso que propõe satirizar diretamente as práticas sociais, como foi tão comum ao longo dos séculos; ele vem, apenas, por meio de uma ironia zombeteira, que rebaixa e expõe o sujeito frente a seu público.

Estudar o riso, no entanto, em nossos tempos, é reconhecer os temores e medos contemporâneos, sendo suas representações a forma de mascarar as vicissitudes mundanas e a falta de determinação do futuro. É a forma de encarar a vida e as inovações dos costumes e da cultura mundial que procura se universalizar. Até a igreja, que repudiou por longos anos a atitude risível, passou a procurar soluções para a descrença mundana no riso.

Passamos, na sequência, para considerações sobre a obra de Lima Barreto que se constitui, como queremos demonstrar, como herdeira de traços significativos desta tradição do riso que ora ressaltamos. 


\section{A literatura brasileira do riso e o projeto estético de Lima Barreto}

É no homem que esta arte da dissimulação atinge o seu ponto culminante: a ilusão, a lisonja, a mentira e o engano, a calúnia e a ostentação, o fato de desviar a vida por um brilho emprestado e de usar máscaras, o véu da convenção, o fato de brincar de comediante diante dos outros e de si mesmo, em suma, o gracejo perpétuo que em todo lugar goza unicamente com o amor da vaidade, são nele a tal ponto a regra e a lei, que quase nada é mais inconcebível do que o aparecimento, nos homens, de um instinto de verdade honesto e puro. (NIETZSCHE, 2001, p. 08) 


\subsection{O riso na Literatura Brasileira}

Sylvia Telarolli (1999), no artigo Entre a fúria e a esperança, o fel e o riso: presença da sátira na literatura brasileira, ao discutir a constante presença da sátira que acompanha as escrituras literárias brasileiras, ressalta que:

Temos então um fio que corre sempre contra a corrente na nossa literatura, uma produção marginal, que expressa um olhar "às avessas", satiriza a política e os costumes e ao mesmo tempo faz o arremedo da literatura "séria", oficial, mais convencional e conceituada, revelando também seus limites, ao parodiar clichês, mimetizar tiques e sestros pasteurizados. (p. 70).

A partir do pressuposto da pesquisadora, que acredita no riso enquanto forma mais cabível de questionamento social, sumariamente, avaliaremos algumas escrituras que fizeram do cômico um dos principais conteúdos em seus enredos. Porquanto, a literatura brasileira nasceu no século XVI, especificamente como escrituras de informação, que seriam, em especial, descrição da terra brasileira à metrópole portuguesa. $\mathrm{O}$ principal representante dessa fase secular foi o Padre José de Anchieta (1534-1597), com seus autos sacros voltados para a catequização dos índios. Havia, nessa fase, alusão sobre o riso, sobretudo, pela reação dos índios em face das representações teatrais de ordem sublime retratadas nas escrituras. O Barroco ajeitou a máquina discursiva sob a voz de importantes ideólogos, como o Padre Antônio Vieira (1608-1697) e seus sermões de educação religiosa e moral. Além do jesuíta, a figura contundente de Gregório de Matos (16361696) e sua larga crítica ao povo baiano e seus contemporâneos, a posição jocosa perante o clero. Plasma sua obra por "uma estética de fácil entendimento, de imagens e formas realistas como a própria vida das coisas, dos seres, das pessoas, mas real, séria e cômica como a vida" (FREITAS, 1981, p. 71). Há ainda o escritor Bento Teixeira (1561-1618) que editou sua obra Prosopopeia (1601). As escrituras desse período traziam em suas páginas o teor do riso, muito marcado pela sátira aos costumes locais e aos homens importantes da sociedade.

No período árcade, esse ideário crítico que selou as primeiras narrativas é deixado de lado em nome da singeleza do campo; a estilística se aproxima mais do leitor pela simplicidade empregada, contrária às grandes metáforas que marcaram as escrituras barrocas; a epopeia foi o gênero de destaque naquele momento, sob a pena de escritores como Santa Rita Durão (1722-1784) e Basílio da Gama (1740-1795), buscando a exaltação de um povo e de uma sociedade, em contraposição ao ideário do riso que trabalha com o rebaixamento. Todavia, nesse período ainda foi possível encontrar a sátira 
nas rápidas páginas de Cartas Chilenas, do escritor Tomás Antônio Gonzaga (17441810).

O Romantismo, consolidado pela vinda da família real para o Brasil e a ascensão da imprensa, possuía como principal conteúdo de suas narrativas a exaltação das coisas locais, na tentativa iminente da criação de uma literatura genuinamente brasileira, atendose ao retrato dos aspectos locais e à exaltação da pátria. Esse ideário que marcou a época é uma justificativa central para, o que nos parece, o pouco riso das obras literárias do período. Mas é aqui que se dá o surgimento de uma importante escritura cômica, Memórias de um sargento de milícias (1852), que se tornou uma das principais inspirações das obras realistas e que possuía em seu enredo traços das narrativas que selariam a segunda metade do século XIX. Em suas páginas é possível encontrar o retrato dos costumes do local e os vícios sociais que marcavam a população do momento, tornando-se uma espécie de sátira à sociedade da época. "O primeiro grande malandro que entra na novelística brasileira [Leonardo Filho], vindo de uma tradição quase folclórica e correspondendo, mais do que se costuma dizer, a certa atmosfera cômica e popularesca de seu tempo, no Brasil” (CANDIDO, 2010, p. 22).

O Realismo, por sua vez, consolida o viés do riso e do retrato social grotesco da população, marcado pela miserabilidade que percorre as sociedades e pela visão crítica do tempo e do espaço. O principal escritor que selou esse período foi Machado de Assis (1859-1908), descrevendo a sociedade burguesa grotescamente, por meio do riso e da dura ironia que marcava as situações sociais do período. De seus nove romances, destacam-se aqui suas principais obras: Memórias Póstumas de Brás Cubas (1881), Quincas Borba (1891), Dom Casmurro (1899), Esaú e Jacó (1904) e Memorial de Aires (1908). Além desse retratista social, o período ainda contou com as vozes de autores como Aluísio de Azevedo (1857-1913), escritor de O Cortiço (1890) e de O Mulato (1881) e Raul Pompeia (1863-1895), com O Ateneu (1888). Mais uma vez vemos a sociedade burguesa enquanto alvo do riso literário traçado nas páginas narrativas dessas obras, reafirmando as palavras da pesquisadora Sylvia Telarolli (1999). 


\subsection{O legado do riso brasileiro: Gregório de Matos, Manuel Antônio de Almeida e Machado de Assis}

Pensemos agora sobre três modalidades de riso presentes nas obras de autores de períodos literários distintos: Gregório de Matos, Manuel Antônio de Almeida e Machado de Assis. A produção de Gregório de Matos Guerra (1636-1696), escrita no século XVII, coincide diretamente com a problematização realizada no primeiro capítulo para o surgimento do romance. Ao tratarmos das peculiaridades que marcam o gênero, não apenas estávamos a falar na narrativa em prosa, mas também buscávamos ressaltar uma nova estética que passou a cercear as escrituras a partir do referido século. Walter Benjamin (2012) ressalta que, com a ascensão do romance e sua vitalidade enquanto gênero das práticas burguesas, os outros gêneros tiveram que se adequar ao novo olhar estético e, a exemplo do romance, retratar a nova situação social em voga.

Boca do Inferno foi uma das alcunhas atribuída a Gregório de Matos. Com obra que congrega vários temas sociais, o escritor, por meio do discurso jocoso e satírico, descreveu uma Bahia carnavalizada, em que a essência e a aparência se distanciavam, restando apenas o riso provocado pelas ações sociais dos governates. A sátira menipeia, como forma de composição discursiva que procura mostrar uma visão de mundo contrária ao pensamento dominante, apareceu como conteúdo principal das produções gregorianas, e o rebaixamento do pensamento oficial integra a maior parte da escrita do poeta baiano. Enquanto integrante do Barroco, Gregório de Matos é cultor das grandes metáforas e dos paradoxos atribuídos a esse momento da história literária, formas estilísticas que provocam o riso. Segundo Hansen (1989),

\footnotetext{
Ao poeta barroco nada repugna mais que a inovação, sendo a sua invenção antes uma arte combinatória de elementos coletivizados que, propriamente, expressão individual 'original', representação naturalista do contexto, ruptura estática com a tradição” (p. 16).
}

Sylvia Telarolli (1999) registrou a sátira como um dos principais meios de difusão da literatura brasileira. Tal traço é um dos indiciadores da instabilidade social e política da nação. As diversas mudanças propagadas no seio social proporcionaram a difusão de algumas importantes obras de cunho satírico com viés de protesto tanto contra o sistema político quanto literário. Dessa forma, a união que o artista fazia entre texto e contexto interferia diretamente na forma do gênero, apropriando-se da mistura de variados traços estilísticos para a composição de sua arte. $\mathrm{O}$ poeta barroco, insatisfeito tanto com a política local, quanto com o plano literário do período, reporta-se a uma escritura também 
direcionada às camadas populares, com a mistura linguística que une o oficial com popular, por meio das inversões, da reprodução dos contrates, visando desnudar as leviandades sociais. Na perspectiva do pesquisador Carlos Nogueira (2011),

Na obra poética multifacetada de Gregório de Matos, a sátira é o género quantitativamente mais saliente; encontra-se em praticamente todas as formas cultivadas pelo autor, desde as mais breves como o soneto até às mais extensas, nalguns casos com mais de cem versos, como a canção alirada, a silva, a copla, a letrilha, o romance e o poema em décimas ou em tercetos. (2011, p. 278).

A atenção do poeta é outra: o olhar para o popular e para o cotidiano das pessoas gera um efeito singular na produção literária. Procurando uma poética que desse conta dos problemas humanos, Gregório se aproveitou da paródia e da estilização de vários gêneros para compor seus poemas. A reprodução carnavalizada dos fatos da vida desfaz o herói e aponta o homem social fora dos elementos elevados. Desde os políticos da cidade, os religiosos - padre, freira, bispo - que tinham uma posição privilegiada, os comerciantes, os escravos; todos foram atingidos pela pena do escritor baiano, sendo suas visões e posicionamentos equalizados. Vejamos o fragmento poético abaixo:

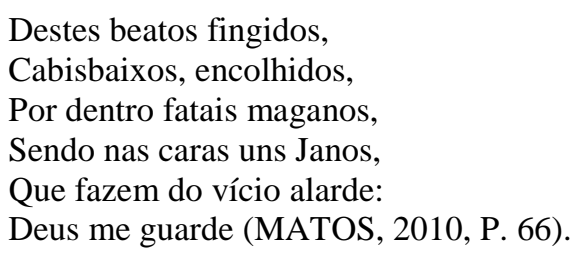

Com o jogo das antíteses, o santo vira humano, com todos os pecados atribuídos ao homem comum. $\mathrm{O}$ beato fingido é o mesmo Jano ${ }^{4}$ que se apresenta à população com o discurso moralizante. O estilo de descrição rebaixa a posição de heroísmo da personagem; mediante a linguagem popular e os adjetivos de destronamento, o espaço vai se carnavalizando; nele a sátira impera como mundividência e como produtora do riso. Os defeitos ocultos, quando levados à praça pública, provocam o riso e expõe o sujeito em cena vital. Tais formas de desnudamento, por meio do reconhecimento dos vícios sociais, procuram despertar a mudança social.

A mistura linguística enuncia a sátira e a decomposição dos estratos literários do poeta baiano em sua época, fazendo da paródia a forma mais plausível de questionamento das estruturas sociais postas. Dessa forma, é possível encontrar na poesia do escritor a sátira política, a sátira com elementos pornográficos, mas também uma poesia cultora do

\footnotetext{
${ }^{4}$ A palavra carrega a acepção de santo.
} 
divino, fazendo, nesse sentido, um percurso em torno do sagrado e do profano. Ora representa a Igreja Católica por meio da sátira, ora se encontram elementos profundos de religiosidade nas linhas poéticas. Sua atenção está dedicada especialmente à figura dos padres, das freiras e do clero que, no caso, eram os representantes da igreja na Bahia. Desse modo, verificamos nas poesias de Gregório de Matos diversos escritos que fazem alusão diretamente às divindades - "Ao Braço do Menino Jesus”, "A Jesus Cristo", "A Maria Santíssima" -, representando uma grande contradição com o estilo satírico do poeta, mas que constroem a pluralidade de estilos e as várias faces possíveis da produção do escritor, e o porquê de ser reconhecido como um importante nome da poesia brasileira. Exemplifiquemos:

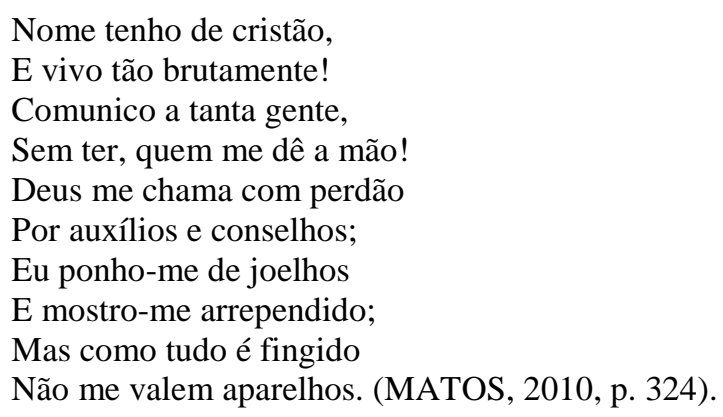

No fragmento acima, a mistura do relato cristão com sujeito pagão conduz ao riso. O sujeito poético, inserido em um mundo que tinha a religião como força da vida, não se vê parte desse mundo. Os contrastes denunciam o cinismo da exposição antitética (arrependido/fingido), construindo a comicidade mesmo nas poesias com teor religioso. É verificável que a maior parte dos poemas do escritor estão diretamente relacionadas aos temas que refletem os problemas do cotidiano do povo baiano, construindo uma contundente crítica à política local. Assim, sua obra destaca-se como um documento vivo dos problemas que assolavam o estado baiano; do mesmo modo, percebemos que as imagens presentes na escritura do autor estão diretamente relacionadas ao retrato das misérias humanas que permeavam o local. A justificativa para o realismo que imprime em suas produções está vinculada a uma atitude responsiva do autor com seu tempo, transitando pelas ruas, observando e registrando os problemas sociais, como no soneto abaixo:

\footnotetext{
A cada canto um grande conselheiro Que nos quer governar cabana e vinha;

Não sabem governar sua cozinha

E podem governar o mundo inteiro.

Em cada porta um bem frequente olheiro
} 


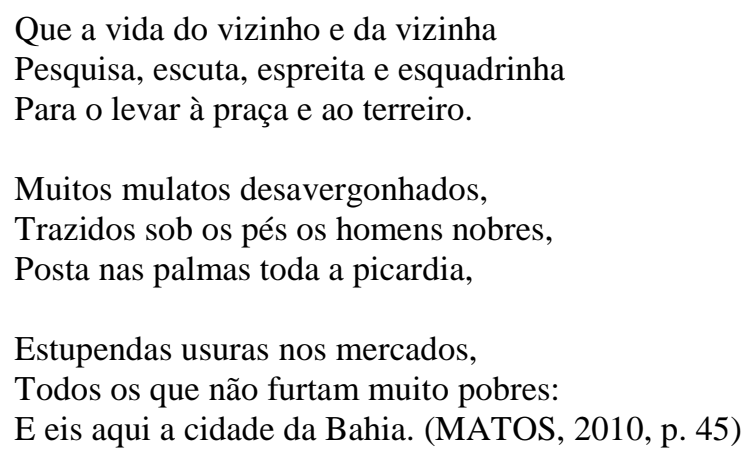

Observamos que a desfiguração social na poesia de Gregório é uma das principais armas da sátira. A cidade, onde reina normalidade cotidiana, é virada aos avessos, passando a ser lida dentro da ótica de um espaço marcado pelas orgias e pela corrupção, de tal forma que os traços se tornam os principais meios de rebaixamento social. A escrita que conjuga o alto com o baixo procura demonstrar, por meio das antíteses, os símbolos de rebaixamento, destronando os detentores do discurso oficial. O grande conselheiro que governa o povo é retirado de suas vestes oficiais e conduzido para o espaço particular, o qual não sabe governar seu próprio lar, mas, mesmo sem habilidades administrativas, quer governar pessoas e instituições circundantes. Por outro lado, a vida mesquinha do cotidiano do povo é levada à praça pública, mediante os escândalos dos espaços domésticos e das usuras dos mercados, denunciando os mercadores e universalizando a vida. O rito carnavalizado percorre toda a escritura, trazendo as palavras poéticas através da simbólica carnavalesca, em que a visão de mundo equaliza os vários segmentos sociais e denuncia o estado lastimoso no qual a Bahia da época se encontrava.

As imagens de governo, cabana, cozinha, praça, terreiro, picardia, usuras, furto, pobreza e Bahia espocam em uma grande liberdade linguística, contrastando elementos opostos, constituindo vasto paradoxo. O final da escritura se direciona para a Bahia, gerada sobre os símbolos de rebaixamento, em que o oficial e o não oficial figuram no mesmo plano - as autoridades, os mercadores e os escravos são integrantes de um mesmo mundo: da soberba e da ganância. A corrupção manifestada nas descrições dos governantes como sujeitos que roubavam os minoritários se tornou uma das principais chaves de acesso à escritura política gregoriana, e sua crítica se expõe e expõe os defeitos do outro. Iguala-se o sujeito que está na governança como pequeno mercador, pois todos possuem o mesmo ensejo, manifestado no desejo de ascender socialmente, mesmo que para isso tenham de sobrepujar os que se encontram na esfera inferior. Alfredo Bosi (1992) afirma que "O desejo de gozo e de riqueza são mascarados formalmente por uma 
retórica pobre e moralizante, mas afloram com toda a brutalidade nas relações com as classes servis que delas saem aviltadas" (p. 42).

Ademais, o autor possui uma seara de poesias pornográficas, que têm o objetivo da descrição de relações amorosas, marcadas pelo extremo exagero nas expressões. Mas essas imagens poéticas hiperbólicas surgem como marcas nodais nas produções barrocas, conforme João Adolfo Hansen (1989); além do mais, essa forma de escrita popular é uma arma de combate às poéticas postas, por se desvincular de um discurso dominante e conjugar o erudito com o popular. Por exemplo:

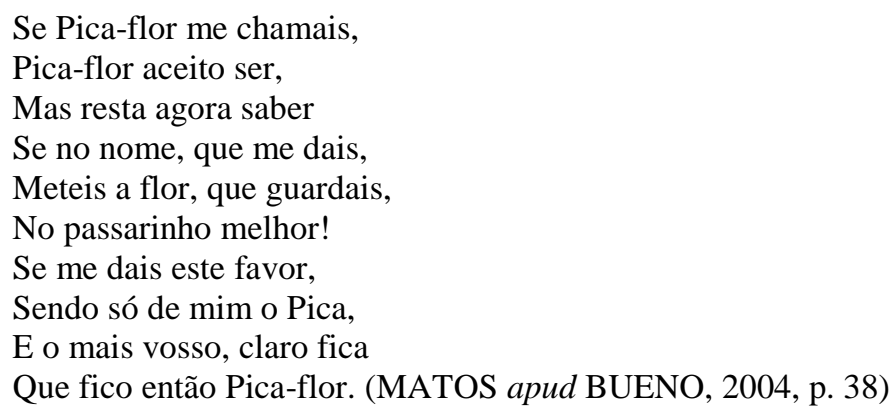

O desvendamento do corpo aparece como uma atitude de enfrentamento social, construindo uma produção poética altamente ousada, o que o levou a ser repudiado socialmente. Em contrapartida, essas formas de expressões poéticas devem ser vistas "sob o signo do rebaixamento na tradição popular" (FREITAS, 1981, p. 95).

A sátira de Gregório de Matos ao sistema social baiano o inscreveu na história literária brasileira como um dos principais tradutores da cultura do momento. As narrações grotescas, as inversões, as paródias realizadas são frutos de um estilo poético crítico que já tinha seus pés fundados em uma ampla tradição de literatura. Desde a sátira luciânica são visíveis os rebaixamentos narrativos; suas obras, que no momento de escritura eram levadas aos leitores em forma de poemas curtos, denunciam um grande conhecimento sobre as relações sociais que envolviam os vários ramos da sociedade, fazendo-lhe cantador das várias formas de vida do período. Dessa forma, essa escritura pode ser lida enquanto uma das maiores literaturas de protesto em solo brasileiro, que rebaixou, expôs, enunciou o espaço carnavalizado das relações sociais. E ainda desmascarou os papéis, retirou as máscaras e demonstrou o cidadão em suas atitudes mais baixas. Ao final de tudo, concebemos "Um Gregório de Matos vagamente anarquista, misto de vanguarda do proletariado, de intelectual orgânico e de libertinagem intelectual e sexual, na paródia do estilo alto da cultura oficial” (HANSEN, 1989, p. 22). 
Após Gregório de Matos, damos um salto nos interstícios literários brasileiros. $\mathrm{O}$ autor em foco agora é Manuel Antônio de Almeida (1831-1861), carioca que viveu apenas 30 anos, mas sua presença na historiografia literária brasileira é de fundamental importância. Jornalista, antes de tudo, o escritor carregava a verve crítica esmaecida nesse âmbito de escritura; mesmo que a profissão de jornalista não figurasse em meados do século XIX, como uma profissão de relevo, esse escritor conseguiu viver do jornalismo, assim como foi um dos principais escultores jornalísticos da "pátria amada":

\begin{abstract}
Era jornalista profissional (numa época em que os jornais eram quase amadores), poeta (infrequente), dramaturgo (ocasional), tradutor (de francês e italiano), polemista (especialista em enfrentar poderosos), crítico literário (que não poupava nem os amigos), descobridor de Machado de Assis (para quem abriu todas as portas) e romancista (de um só romance, é verdade - mas precisava de outro?). (CASTRO, 2013, p. 07).
\end{abstract}

Essas várias faces de Almeida apontadas por Ruy Castro muito são desconhecidas pelo público leitor, afora isso, até sua figura, às vezes, fica escondida em uma época em que o Romantismo imperava, aventando sóis exclusivos a José de Alencar e a Joaquim Manuel de Macedo. Dentro desse leque que Castro nos abre, algumas informações são fundamentais para perfilar o escritor carioca de Memórias de um sargento de milícias: a imagem do polemista social aparenta-se a mais atraente, no sentido raso do questionamento social e da maneira que essa crítica é recepcionada pelo leitor. Participando de alguns jornais importantes do período, Almeida integrou o semanário Correio Mercantil, no qual publica a crônica "O riso", em 1854. A crônica abre com a seguinte observação: “O homem é o único animal que se ri”. Seguindo as considerações sobre o ato cômico, ele explica: "o homem é o único animal que se ri, porque é o único animal que é tolo" (ALMEIDA, 1991, p. 27). Essas observações críticas sobre a figura humana nos conduzem ao riso e às comédias de costumes, que levavam os espectadores ao riso pelo absurdo crítico levantado para esse mesmo público. A herança dessas comédias é possível ser vislumbrada nas cenas representativas que não assustam o leitor, nem mexem com seus dogmas, mas o faz reconhecer-se naquelas atitudes mesquinhas que estão plantadas no seio da sociedade.

Manuel Antônio de Almeida escreveu, como já apontado, um único romance, Memórias de um sargento de milícias, - entre os anos de 1852 e 1853 , o livro apareceu em folhetins, a edição em livro saiu entre os anos de 1854 e 1855 . No início das publicações em jornal, o escritor contava apenas com 20 anos de idade. Nota-se que, enquanto obra proveniente de folhetins, já se reportava à novela e ao relato dos costumes 
do povo. Essa escritura é um dos casos mais singulares da história literária brasileira, passando a ser vista como a obra-chave para as novas tendências literárias que vigoravam a seguir e que foi seminal para o Realismo no Brasil. A relação com Machado de Assis, a quem se doou a ensinar a jogatina narrativa de uma revelação cômica da vida, vai proporcionar no escritor de Dom Casmurro um novo estilo, ferino, embainhado pela ironia, mas que não foge aos ambientes burgueses. Berta Waldman (1996) ressalta, sobre a obra de Macedo: "Prodígio de humor e ironia, isento de qualquer traço idealizante, no romance não há lugar para as tintas sentimentais e heroicas nem para o abuso de peripécias inverossímeis, tão do gosto do romance romântico da época”. (p. 9). A falta de atenção ao protagonista, sendo revelado seu nome apenas por volta da metade da obra de Macedo, corrobora com o discurso da pesquisadora, e aponta o tratamento atribuído ao herói como integrante de uma tradição de literatura risível que está em Cervantes, perpassa Gógol e continua a se manifestar enquanto traço essencial das produções romanescas desde então.

Antonio Candido (2010) salienta que Memórias de um Sargento de Milícias seria uma espécie de romance de costumes, retratando, de certo modo, a paisagem carioca, sendo uma escritura que antecipou o Realismo que marcou o final do século XIX. A obra do escritor trouxe em suas páginas o primeiro malandro da literatura brasileira. $\mathrm{O}$ enredo é endossado pela trajetória que se inicia com Leonardo Pai, alcançando Leonardo Filho, por isso reconhecemos na produção romanesca de Macedo uma galeria de tipos sociais representantes do cotidiano carioca de sua época, sendo possível afirmar que o heróicômico Leonardo Filho apontou um novo conteúdo discursivo ao encenar as necessidades do sujeito pobre para vencer as amarras da vida. Dessa forma, "Memórias é feita pela associação íntima entre um plano voluntário (a representação dos costumes e cenas do Rio) e um plano talvez na maior parte involuntário (traços semi-folclóricos, manifestados sobretudo no teor dos atos e das peripécias)" (CANDIDO, 2010, p. 25).

O narrador romanesco, produtor de um discurso eloquentemente cômico, conta sua história de uma forma brincalhona, dando a mesma atenção a todas as personagens da narrativa: as quais todas são frutos do rebaixamento, fugindo, de certo modo, a uma vida oficial, e colocados em uma praça pública, onde o carnaval impera como o grande mediador das relações sociais. Os casos, frutos do ambiente domiciliar, são transportados para a rua e passam a ganhar caráter universal, demonstrando que tais peripécias 
pertencem ao ser humano, e não são frutos apenas da camada pobre populacional. Um exemplo é a presença do Major Vidigal, que figura dentro da trama fora das vestes de oficial: o desnudamento do sujeito o põe com todas as fragilidades humanas, rebaixando a figura do herói que se levantava perante o vestuário. Além do mais, o uso do diminutivo no trato das personagens, por consequência, retira o poder da farda e aproxima os homens: "Era o Vidigal um homem alto, não muito gordo, com ares de moleirão; tinha o olhar sempre baixo, movimentos lentos e voz descansada e adocicada" (ALMEIDA, 2013, p. 52). Esse novo tratamento atribuído ao herói, feito por meio do riso, está expresso nas palavras de Bernardo de Mendonça (1991):

As Memórias de um Sargento de Milícias podem ser lidas como um jogo entre
a zombaria, a orfandade e a proteção: o romance não relata apenas a história
das perseguições dos gaiatos e suciantes da cidade pelo Major Vidigal,
comandante da guarda; relata também a história de um gaiato, o protagonista
Leonardo, contra a perseguição do desamparo. (p. XV).

O romance, narrado em terceira pessoa, é constituído de duas partes, composto por capítulos curtos, rastro da própria escritura folhetinesca. A escrita humorística presente até nos títulos dos capítulos (Primeiros infortúnios, Despedida às travessuras, Progresso e atraso etc.) - que acompanha cada capítulo visa a chamar a atenção do leitor para cada cena da narrativa, fazendo dos episódios risíveis, construídos a partir dos conflitos, motivos reais de entretenimento do leitor. Ao longo da trama é possível perceber a voz do narrador chamando constantemente a atenção do leitor para a história narrada, proporcionando, de certa forma, a concretização dialógica. "Os leitores devem estar fatigados de histórias de travessuras de crianças" (ALMEIDA, 1996, p. 73). Essa alusão ao espectador ao longo do romance pode ser encontrada em quase todos os capítulos, apresentando, de alguma maneira, uma injunção irônica, pois, ao querer se desculpar pela apresentação de um fato recorrente, convida-o a percorrer mais uma anedota a ser narrada no romance.

A publicação da obra em folhetins, teve o espaço por mais ou menos um ano. Essa permanência da novelística macediana por longo tempo no semanário demonstra tanto a aceitação do público do novo estilo romanesco, quanto à satisfação dos responsáveis pelo espaço no jornal. Do mesmo modo, o que buscamos destacar com esse parêntese é um novo olhar para os modos de representação social-literária do período, apontando o reconhecimento dos leitores às novas características romanescas, que só vai se consolidar com Memórias Póstumas de Brás Cubas, em 1881. Por sua vez, o romance de crítica social começa a nascer em terras brasileiras a partir de uma grande estilística risível, 
apontando, mais uma vez, a comicidade como espaço ideal de rebaixamento social e unificação discursiva. Colocar todos os homens em um único plano é buscar direitos iguais para todos. A figura do herói épico, que se via figurado enquanto um Deus, superior aos demais sujeitos, é quebrada, e a felicidade aclamada nas narrativas românticas, as qualidades exaltadas que esse período da história procurava demonstrar começam a ser desconstruídas.

Memórias de um Sargento de Milícias inicia com ironia ao trazer para abrir a história a expressão "ERA NO TEMPO do rei", visando a elencar uma crítica aos costumes da época e ao atraso que selava a população do período. A narração se desenrola com a descrição da mudança que prevaleceu com os meirinhos, funcionários da justiça que formavam uma classe tradicional no Rio de Janeiro, nos tempos do rei e nos tempos atuais. O retrato elaborado pelo narrador do romance objetiva menosprezar a fama desse grupo de cidadãos nos tempos hodiernos, sendo que um dos personagens principais dessa casta é descrita, em sua velhice, como "moleirão e pachorrento" (ALMEIDA, 1996, p. 16). O detentor do despretensioso adjetivo é uma das principais personagens da obra, reconhecida como Leonardo-Pataca, pai do primeiro anti-herói da literatura brasileira, Leonardo Filho. A representação carnavalizada da sociedade enuncia uma nova configuração narrativa, diferente ao que preponderava em solo brasileiro e aponta caminhos para as mudanças que o espaço literário já almejava perante a sociedade de classes e o capitalismo em voga. O romantismo desfigurava a sociedade brasileira e o realismo tardio, bem depois de outras nações, como a França, procurava novos rumos para o fazer literário do Brasil.

O enredo da história prossegue com o relato do relacionamento de Leonardo e Maria, resultando no nascimento de seu primeiro filho, dentro de sete meses. O menino é descrito como o herói da rapsódia, mas esse qualificativo é desconstruído desde as primeiras páginas da narrativa, apresentando uma criança travessa desde tenra idade. "Era colérico; tinha ojeriza particular à madrinha, a quem não podia encarar, e era estranhão até não poder mais" (ALMEIDA, 1996, p. 17). A descrição põe o leitor, mais uma vez, em confronto com a figura do herói por meio do discurso irônico do narrador, que, mesmo utilizando a terminologia de herói, aponta características totalmente contrárias à de um herói, levando o leitor a constatar que está à frente de um verdadeiro anti-herói. Candido (2010) corrobora com tal perspectiva ao ressaltar que seria "o primeiro grande malandro 
que entra na novelística brasileira, vindo de uma tradição quase folclórica e correspondendo, mais do que se costuma dizer, a certa atmosfera cômica e popularesca de seu tempo, no Brasil”' (p. 22).

Macedo, um dos fundadores do carnaval carioca, não poderia esquecer os traços desse importante movimento em seu romance: o narrador romanesco informa o leitor que a história se passa no carnaval. O caráter carnavalesco desnuda a obra e enuncia o caráter risível que irá preencher a trama. O menino, fruto de um relacionamento marcado por uma "pisadela e um beliscão", a quem todos esperavam com grandes qualidades, desde as primeiras descrições, quebra a expectativa da família, vivendo a contrariar suas esperanças, principalmente na realização de constantes travessuras. "Formidável menino de quase três palmos de comprido, gordo e vermelho, cabeludo, esperneador e chorão" (ALMEIDA, 1996, p. 17). Os adjetivos que descrevem o herói, o desmontam imediatamente em anti-herói perante as expressões de rebaixamento. $\mathrm{O}$ trocadilho, no entanto, que denota a relação entre seus pais, tecerá o fio da narrativa do começo ao fim.

\footnotetext{
Leonardo fingiu que passava distraído por junto dela, e com o ferrado sapatão assentou-lhe uma valente pisadela no pé direito. A Maria, como se já esperasse por aquilo, sorriu-se como envergonhada do gracejo, e deu-lhe também em ar de disfarce um tremendo beliscão nas costas da mão esquerda. (ALMEIDA, 1996, p. 16-17).
}

O que o narrador do romance procura destacar desde as primeiras linhas é que o nascimento do herói da rapsódia não é feito do amor entre o casal, mas de um relacionamento brumontes, respaldado, dessa forma, na brutalidade das ações. $\mathrm{O}$ grotesco da narração aponta o homem fora dos elementos elevados; além do mais, os traços da linguagem coloquial são evidentes na escritura, procurando, sobremodo, alcançar o leitor, com seu discurso do dia a dia, com seus problemas e fatos que estão distantes da representação oficial. A ironia do limiar do relacionamento dos pais do menino irá transpassar a história inteira, tentando legitimar as atitudes travessas do malandro, sendo também um recurso narrativo que, ao tentar justificar as atitudes de malandragem, quer apenas reafirmar o anti-heroísmo humano.

O aumento das proporções do narrado, um dos principais recursos da sátira menipeia, é um artifício bastante utilizado pelo romancista para chamar a atenção do leitor para o absurdo do cotidiano que está soterrado por um estilo romântico de literatura, que procura criar heróis e mocinhos numa terra onde não cabem heróis. A descrição inicial do menino Leonardo caracteriza-se principalmente pelo exagero dos acontecimentos, 
levando ao ridículo e rebaixando os acontecimentos que compõem a saga romanesca. "Mamou duas horas seguidas sem soltar o peito" (ALMEIDA, 1996, p. 17). Essa estilização narrativa também está presente no ato da briga entre Maria e Leonardo Pataca e na intromissão da criança que rasga os papéis do pai. Ao ver seus papéis rasgados, a atitude do patrono é totalmente violenta e a descrição da cena se torna risível pelo absurdo do acontecimento. "Suspendeu o menino pelas orelhas, fê-lo dar no ar uma meia volta, ergueu o pé direito, assenta-lhe sobre os glúteos atirando-o sentado a quatro braças de distância" (ALMEIDA, 1996, p. 38). Essas descrições cômicas da vida familiar integram uma tradição de literatura; e a figuração das cenas, ultrapassando o real, remontam a Rabelais enquanto pioneiro dos destronamentos humanos e do riso literário.

Outro importante momento para a descrição risível pode ser apontado no diálogo entre o padrinho de Leonardo e sua vizinha, assim como a presença irreverente de outro morador da rua, sendo essa cena cômica motivada pela constante descrença da população da cidade sobre o conhecimento de Leonardo Filho, fato esse que não era aceito pelo padrinho do menino.

....a vizinha que estava à janela disse-lhe em tom de zombaria: - Então, vizinho, como vai o seu reverendo? Um velho que morava defronte, e que também se achava à janela, desatou a rir com a pergunta. O compadre foi às nuvens, avermelhou-se lhe a calva, franziu a testa, porém fez que não tinha ouvido. A vizinha pôs-se também a rir. (ALMEIDA, 1996, p. 48).

A briga em praça pública demarca o escândalo social, a exposição de acontecimentos do ambiente privado é transferida para a rua; assim os que anteriormente eram particulares se universalizam, conduzindo ao riso; do mesmo modo, percebemos a apropriação da sátira menipeia na escritura de Macedo, representada pelos escândalos, que são típicos do romance e que fogem ao oficial que se resguardava na epopeia. Assim, o rebaixamento em praça pública aponta para a universalização narrativa e a carnavalização da vida. Os fatos do ambiente doméstico tornaram-se centrais na escritura do prosador; trazendo o sujeito fora da vida oficial e equalizando seu discurso, sua vida com a de qualquer outro cidadão. Esse rebaixamento narrativo assinala para o rebaixamento da figura do herói; não existe mais um sujeito com qualidades superiores que as das demais pessoas. Todos passam a integrar o espaço carnavalizado, que seria, em especial, o espaço da vida.

As características novelísticas preenchem boa parte do enredo: tais traços podem ser verificados nas cenas em que a população vigiava os acontecimentos que ocorriam na 
casa de Leonardo. Além do mais, caracterizado por sua natureza popular, o romance também pode ser exemplo de um duplo: ordem e desordem, como aponta Candido (2010). No caso, o anti-herói Leonardo Filho vaga entre essas duas vertentes em solo brasileiro. Esse caráter, na perspectiva de Antônio Candido, sofre grande influência dos outros personagens da obra e não está petrificado apenas nos personagens malandros da trama, também é característica dos personagens representantes da verdade, como o é Leonardo Pai. Nesse sentido, os acontecimentos se tornam os verdadeiros responsáveis pela condução dos personagens ora para a ordem, ora para desordem. Segundo Waldman "Ao praticar ações tidas como reprováveis, as personagens fazem outras dignas de louvor, que as compensam. E como todos são assim, ninguém merece censura" (WALDMAN apud ALMEIDA, 1996, p. 11). O que resta desse duplo é uma luta entre os representantes da ordem e os da desordem; por isso, o resultado dessas prerrogativas é o desenho da sociedade brasileira em formação, em que não há espaço para homens superiores e inferiores.

A escritura de Macedo posta-se como uma grande crítica ao espaço literário de sua época. "No entanto, a certeza de que estamos perante a retomada de um modelo narrativo baseado no anti-herói como paródia crítica da sua sociedade contemporânea é inegável" (GONZÁLEZ, 1988, p. 56). A representação do herói rebaixado é a contraversão de uma sociedade de heróis que, por suas figurações e endeusamento, por suas características idealizadas, procuravam retornar à mistificação de um povo e de uma cultura. É uma grande ironia ao modelo de literatura que se propagava no momento; do mesmo modo, a escritura aponta caminhos para uma nova fórmula que represente a vida em sua essência, com os homens nas situações reais de vivência, fora dos elementos elevados que demarcam as máscaras sociais. A deturpação do conteúdo humano, de certa forma, encontrava-se violada nessa narrativa, sendo a comicidade o espaço profícuo para a denúncia de um estilo literário alienante.

Após Manuel de Antônio de Almeida, mergulhamos na prosaística machadiana. Joaquim Manuel Machado de Assis (1839-1908) é muito reconhecido nas letras brasileiras e estrangeiras. Com uma biografia que inicia com a escritura jornalística, o sucesso de vida do prosador o coloca como o presidente-fundador da instituição cultural e literária mais importante do Brasil, a Academia Brasileira de Letras. É reconhecido nos meios literários principalmente pela força discursiva de seus narradores. Para Ronaldes de Melo e Souza (2005), 
Em Machado, o narrador se compraz na mobilidade dos gestos e atos, assumindo todo gênero de caracteres, desempenhando diferentes papéis, articulando uma alternância sistemática de perspectivas, modulando vários pontos de vista, sempre recusando a inflexão inercial de se imobilizar na representação doutrinária de um só papel, na adoção monológica de um ponto de vista pretensamente normativo. (p. 15).

Escritor de poesia, crônicas, contos e romances, novelas, teatro e críticas, Machado de Assis se consagra como um dos maiores escritores da literatura brasileira, sendo a prosa romanesca sua produção mais reconhecida. A escrita do romancista é muito estimada pela profunda ironia que mantém em suas linhas, sendo esse estilo apontado por Teixeira "como meio de investigação ética" (TEIXEIRA, 1993, p. 58). Ademais, essa ironia é vista como uma das principais características da escritura do prosador, aliandose a um estilo rebuscado de linguagem, conduzindo para o que a crítica passou a chamar de "finura". Para Candido (1995, p. 15), "A ironia fina, estilo refinado, evocando noções de ponta aguda e penetrante, de delicadeza e força juntamente. A isso se associava uma ideia geral de urbanidade amena, de discrição e reserva”. O caráter filosófico e risível das obras de Machado conduzia para o retrato humano, mas sem chocar as morais burguesas do final do século XIX, como assinala Candido. Essa última faceta separa, de alguma forma, as obras de Machado das obras macedianas, apontando um novo estilo de fazer artístico que bebeu da tradição cômica anterior, mas que a estilizou e passa a escriturar uma fórmula literária diversa.

Para Laura Goulart Fonseca (1996), existem três chaves de acesso à escritura do romancista: o drama de caracteres, a narração em primeira pessoa e a constante presença da sátira. A escrita tragicômica surge como uma forma de denúncia aos problemas humanos; da mesma forma, com uma prosa permeada pela tragicidade, a comicidade é a forma de superação dos momentos difíceis, surgindo como um atenuador dos problemas sociais. Se Macedo inaugura a narrativa do herói rebaixado, Machado é apenas um afirmador dessa tradição, uma vez que os heróis de sua prosaística são sempre apresentados ao leitor de forma rebaixada. A escritura em primeira pessoa, em Memórias Póstumas de Brás Cubas (1881), por exemplo, confronta a existência do próprio protagonista, apontando a visão do herói consciente tanto dos problemas do outro, quanto de suas próprias fraquezas. Narrada de uma forma galhofeira, enunciada pelo próprio narrador, a narrativa porta-se como uma grande interpretação da realidade e de análise psicológica do cotidiano social, inserindo as personagens romanescas apenas enquanto alegorias dos costumes de um tempo. O caso de Pandora ilustra bem essa assertiva, em 
que a vida do homem se assemelha a uma grande doença, imbuída pela ganância social, quer superar o outro acima de tudo. Vejamos o excerto abaixo:

\begin{abstract}
Os séculos desfilaram num turbilhão, e, não obstante, porque os olhos do delírio são outros, eu via tudo o que passava diante de mim - flagelos e delícias, - desde essa coisa que se chama glória até essa outra coisa que se chama miséria, e via o amor multiplicando a miséria e via a miséria agravando a debilidade. Aí vinha a cobiça que devora, a cólera que inflama, a inveja que baba, e a enxada e a pena, úmidas de suor, e a ambição, a fome, a vaidade, a melancolia, a riqueza, o amor... (ASSIS, 2013, p. 69).
\end{abstract}

As antíteses que preenchem a escritura são os bens que Pandora carrega em sua mala - "o bem e o mal", mas também a "esperança". As maiores contradições da existência, vida e morte, também estão com Pandora, reafirmando apenas que o homem nasceu para morrer -, são antíteses da vida humana que o próprio narrador ri de tão grande espetáculo. O distanciamento narrativo nessa obra surge como uma crítica aos valores humanos e retorna a Luciano, com Diálogo dos Mortos; e a Dostoiévski, com "Bóbok"; ao qual a conversa dos mortos, figura como a liberdade narrativa para criticar e brincar com os valores humanos. Machado é visto como um grande parodista. Em especial, o retorno a várias outras narrativas, a relação dialógica que se estabelece um número exacerbado de obras dignifica o conhecimento do escritor carioca e aponta para uma tradição literária do riso. Só em Brás Cubas é possível perceber o diálogo com Stendhal, Shakespeare, Sêneca, Antigo Testamento, Homero, Bocage, Cervantes, Byron, apenas para citar alguns nomes e contribuidores para o discurso machadiano.

A criação do Emplasto Brás Cubas é uma grande ironia à humanidade, pois a função primordial do medicamento não era salvar vidas, mas dar fama ao narrador. A busca era o sucesso em si, e isso iria provocar a inveja no outro, resultando a mulher amada em seus braços: "a minha ideia trazia duas faces, como as medalhas, uma virada para o público, outra para mim. De um lado, filantropia e lucro; de outro lado sede de nomeada. Digamos: - amor da glória" (ASSIS, 2013, p. 58). Entretanto, o medicamento ficou apenas na vontade. A figura do herói fracassado continua enquanto conteúdo principal das narrativas realistas e não foi devotado ao protagonista machadiano o impasse da glória. Brás Cubas, Rubião, Bentinho, Aires, todas personagens derrotadas pela vida, num jogo em que o trágico e o cômico comungam a mesma hóstia e que falam de uma vida, que mesmo vencida, segue andando, e o homem continua a viver em sua alegre e triste existência. Para Fonseca (1996),

O mundo narrado em Memórias Póstumas de Brás Cubas é o mundo do Humanitismo, onde a guerra, a inveja e a vingança imperam. Machado de Assis 
se vale da técnica da incongruência e, pelo exagero, ridiculariza os valores dessa sociedade de aparências, que tem uma face virada para o público e outra virada para si mesma. (p. 77).

Perante a constatação da pesquisadora Fonseca, é importante ressaltar que a função do riso na prosa romanesca machadiana ocorre principalmente como forma de denúncia social. A alegoria do defunto surge como meio de distanciamento narrativo, possibilitando a liberdade crítica e a carnavalização do espaço social carioca. Além do mais, o jogo de aparências foca o sujeito fora dos elementos desviantes e rebaixa a burguesia do final do século XIX, demonstrando, por meio dos defeitos tanto do herói como das outras personagens que compõem a narrativa, os vícios humanos equalizados e a falta de distanciamento entre os discursos e os modos de vida.

A narrativa Quincas Borba (1891), que está alinhada à anterior por via da teoria do Humanitismo e pelo personagem que a nomeia, carrega em suas páginas uma grande filosofia de Vida. A representação tragicômica permanece girando ao redor dos textos de Machado. Pautada na passagem da herança do filósofo Quincas Borbas para o professor primário Rubião, a narrativa segue os passos do Humanitismo que já havia perpassado no romance anterior:

Não há morte. O encontro de duas expansões, ou a expansão de duas formas, pode determinar a supressão de uma delas; mas, rigorosamente, não há morte, há vida, porque a supressão de uma é a condição de sobrevivência da outra, e a destruição não atinge o princípio universal comum.” (ASSIS, 2009, p. 58).

Com esse hipertexto narrativo, de acordo com Ronaldes de Melo e Souza (2006), vemos que "no drama cosmo-antropogônico do humanitismo, nada se perde, porque o aniquilamento de um ser propicia o surgimento de um outro" (p. 124) A explicação do filósofo Quincas Borba surge a partir da morte da avó de Rubião, a qual morreu atropelada por um cocheiro; dessa forma, a morte da parente é justificada porque aquele tinha fome, então ele precisava comer. A morte de um é a condição de sobrevivência do outro. Eis a relação tragicômica da vida, em que sobrevivem os mais fortes. Em um paralelo com a vida social carioca, ao Brasil não cabia mais o jogo de heranças, visto que a sociedade capitalista ascendeu e suprimiu a outra classe, e quem não trabalhava era sufocado pela nova estruturação social - esse é o grande mote da narrativa.

Rubião foi a grande experiência do narrador romanesco machadiano. Ganhando a herança, o protagonista deixa sua cidade natal, Barbacena, em Minas Gerais, e passa a residir em Botafogo, no Rio de Janeiro. Entretanto, a ingenuidade o faz perder todo o dinheiro ganho. Marcado por fatos como a entrada na vida da personagem de duas outras 
figuras - Cristiano Palha, agiota assíduo e símbolo do capitalismo, e, sua bela esposa Sofia, que conquistou rapidamente o coração de Rubião -, o protagonista procura se estabilizar em um mundo movido pelo capital. A certeza que a herança nunca iria se acabar, - "Quando o testamento foi aberto, Rubião quase caiu para trás. Adivinhais por que. Era nomeado herdeiro universal do testador" (ASSIS, 2009, p. 66). - leva Rubião a mergulhar na ilusão que tem como resultado final a morte e a comprovação da teoria do Humanistismo. Palha e Sofia ganharam; o mundo capitalista ganhou dos arcaicos modos de vida por via da herança:

\begin{abstract}
As batatas fizeram-se para a tribo que elimina a outra, a fim de transpor a montanha e ir às batatas do outro lado. Justamente o seu caso. Ia descer de Barbacena para arrancar e comer as batatas da capital. Cumpria-lhe ser duro e implacável, era poderoso e forte. E, levantando-se de golpe, alvoroçado, ergue os braços exclamando: - Ao vencedor, as batatas! (ASSIS, 2009, p. 71).
\end{abstract}

A descrição final, mesmo com o aspecto trágico do romance, marcado pela representação carnavalizada da vida de Rubião e seus anseios de ascender social e financeiramente na vida, não perde o relato cínico e cômico que o autor constrói ao longo do romance: "Chora os dois recentes mortos, se tens lágrimas. Se só tens riso, ri-te! É a mesma coisa. O cruzeiro, que a linda Sofia não quis fitar, como lhe pedia Rubião, está assaz alto para não discernir os risos e as lágrimas dos homens" (ASSIS, 2009, p. 297). São os risos do vencedor em cima das lágrimas do vencido, condição necessária para a sobrevivência das espécies. Outro aspecto inerente às lutas de classe parece-nos que é a constatação que quem está na classe de baixo não tem condições de ascender socialmente para a classe superior. Caso o venha fazer, é derrubado pelo sistema capitalista; ou talvez denuncie apenas o sistema de herança que não cabia mais no novo sistema burguês que estava surgindo, marcado pelo trabalho, o que faltava ao personagem principal dessa narrativa. Para Fonseca (1996), “O narrador está constantemente rindo, ainda que tragicamente, de tais personagens. Pela sátira, exagera e distorce as atitudes contraditórias e, dessa forma, o leitor as percebe como risíveis" (p. 96).

Para além desses romances que compõem a chamada fase realista do prosador, que ainda contou com renomadas escrituras, como Dom Casmurro, Esaú e Jacó e Memorial de Aires, os contos foram solo fecundo da produção risível e irônica de Machado. Um dos elementos que mais chama a atenção nessas narrativas do escritor e que o faz ser comparado a Edgar Allan Poe é a forma como prendem o leitor às ações representadas. Seus contos são marcados pelo suspense, às vezes pelo fantástico, os quais não deixam o leitor largar as páginas até encontrar o ponto final. O riso se manifesta 
largamente nessas narrativas, atribuladas, em especial, pela mensagem - ou mesmo a moral - que é lançada para o leitor. "A cartomante" com a crença de Camilo nas cartas; "O esqueleto" com a enigmática figura do Dr. Belém e o esqueleto de sua esposa, provocam o terror e o suspense; o mesmo sentimento de terror e sadismo é construído em "A causa secreta" e em o "O enfermeiro"; o espelho e a representação teatral das duas almas humanas em "O espelho"; e terminamos esse relato sobre os contos machadianos rindo com a Igreja que o Diabo criou em "A igreja do Diabo". Todas essas narrativas curtas são arquitetadas pelos expedientes estratégicos de narração na contística do autor carioca. A ironia e o riso, ao apontarem para os defeitos humanos, retiram do túmulo para a luz a expressão baudelairiana que afirma que o riso está ligado ao erro porque é humano: o erro é o que humaniza o homem.

Além do mais, é necessário arrolar a presença do prosador carioca como um dos iniciadores, junto a José de Alencar e a Manuel Antônio de Almeida, da crônica brasileira.

\footnotetext{
"Machado Assis criou o modelo estrutural da crônica ou, mais propriamente, sua matriz. Nas crônicas machadianas, há diálogos, ironia, leitor-narrador, galhofas, humor, que serve para dizer a verdade, abertura para assuntos variados, em que cada parágrafo é uma crônica dentro da crônica" (p. 31).
}

Para finalizarmos a breve descrição sobre o riso na obra do prosador fluminense, utilizamos a perspectiva de Fonseca apontando que "O riso de Machado de Assis é um riso mordaz, ferino, mas fere justamente para que a sociedade se veja ridícula e busque, por si mesma, a transformação" (FONSECA, 1996, p. 110). O escritor fazia uma arquitetura dos costumes cariocas de sua época e os deslindava, sempre se direcionando ao leitor como seu receptor ativo e integrante do discurso narrado por meio da ironia e do riso ferino, que, às vezes, alcançava a sátira e desnudava a cultura de uma sociedade em metamorfose.

O estudo da obra dos três autores, anteriormente mencionados, procura demonstrar o conteúdo de crítica social presente em suas narrativas. Nota-se que a apropriação do popular enquanto mediador do conteúdo romanesco configura um olhar diferente para o papel da literatura como ação social. O riso é o modo discursivo que esses escritores trouxeram como diferencial para as escrituras; a partir da forma de rebaixamento das ações sociais, a comicidade retira da cena o grande herói e o põe em tom de igualdade com o humano, aproximando-se do leitor e se comunicando com ele. 


\subsection{Um projeto estético do riso: o caso Lima Barreto}

A vida é uma comédia sem sentido, Uma história de sangue e de poeira Um deserto sem luz... (BARRETO, 1997, p. 57).

Osman Lins (1981) defende que os objetivos satíricos da obra de Lima Barreto saltam em primeiro plano. Essa assertiva do escritor-pesquisador dialoga de forma grandiosa com o projeto estético do intelectual, voltado particularmente para uma atenção especial aos retratos das ruas e dos problemas sociais da capital brasileira do século XX. Tais discursos põem em xeque um fazer artístico de crítica militante, franqueado por questões estilísticas risíveis, que encenam os problemas do país, em uma mistura linguística risível, construindo obras que contrastam a situação trágica do Rio de Janeiro com o discurso cômico. O objetivo da literatura, para o autor de Triste Fim de Policarpo Quaresma, é resumido nas palavras de Antônio Candido (2011):

\footnotetext{
Para Lima Barreto a Literatura devia ter alguns requisitos indispensáveis. Antes de mais nada, ser sincera, isto é, transmitir diretamente o sentimento e as ideias do escritor, da maneira mais clara e simples possível. Devia também dar destaque aos problemas humanos em geral e aos sociais em particular, focalizando os que são fermento de drama, desajustamento, incompreensão. Isto porque no seu modo de entender, ela tem a missão de contribuir para libertar o homem e melhorar a sua convivência. (CANDIDO, 2011, p. 47).
}

Dessa forma, dialogando com a perspectiva de Mikhail Bakhtin (2010), Lima Barreto passa a ser lido como um polemista social. As escrituras literárias do ficcionista são vistas como grandes polêmicas plasmadas no seio social carioca. Por meio do discurso ora satírico, ora irônico, rebaixa os principais representantes do discurso do poder do período, uma vez que o objetivo da comicidade de suas obras é chamar a atenção para os problemas sociais esquecidos pelos governantes, além do mais, fazer com que a população reconheça a fragilidade de seus representantes. A função do narrador ideólogo ${ }^{5}$ parece trespassar todas as narrativas do prosador carioca, impondo uma construção discursiva peculiar, envolvendo tanto a forma quanto o conteúdo romanesco de modo carnavalizado e risível. Mikhail Bakhtin (2014) ressalta que "o sujeito que fala no romance é um homem essencialmente social, historicamente concreto e definido, e seu discurso é uma linguagem social" (p. 135). A união do contexto histórico com os fatos

\footnotetext{
${ }^{5}$ Bakhtin (2010) estabelece a categoria do ideólogo enquanto um dos principais componentes que exemplifica a figura do polemista em busca da comprovação de uma tese.
} 
literários propõe uma mudança nas características do gênero literário, uma vez que sinaliza para uma nova preocupação discursiva, em que a sátira se une com a linguagem coloquial em nome da reprodução social do período e de uma literatura que tem por fundamento a comunicação com o leitor. Para Prado,

Em Lima Barreto crítica e marginalização ocupam o centro de uma trajetória singular na passagem para o Modernismo. Se o radicalismo do projeto estético pressupôs, para a definição do escritor, a ruptura com a tradição acadêmica e, nesse sentido, repercutindo no abalo da velha ordem, o fato é que o utopismo do projeto político deixa entrever, na superficialidade da análise histórica, a intenção latente de recuperá-la e, mais do que isso, de pressupô-la como verdade. (PRADO, 1976, p. 13-14).

O ofício de escritor cômico percorre desde o limiar da vida de escritor de Lima Barreto. As investidas fracassadas em dois pequenos jornais - A Quinzena Alegre (1902) e O Diabo (1903) - revelam o projeto estético de escrituras cômicas do romancista bem antes da publicação do primeiro romance, Recordações do Escrivão Isaías Caminha, em 1909. Para Sevcenko (2003), a prosa barretiana descende do "romance francês, na ficção russa, na novela humorística inglesa, nas parábolas do classicismo, no teatro escandinavo, de todos sorveria algo, sem prender-se a nenhum" (p. 194). O painel desenhado ao longo de suas obras vai da representação de vários tipos - o menino negro, o menino rico, o jornalista honesto e o desonesto, - entre outras categorias como o político bem colocado, o advogado imponente, o médico e sua grande fama nas praças cariocas, a mulher e sua posição subalterna perante a figura masculina, a menininha enganada pelos futuros amantes, os loucos situados dentro de um hospício, os estrangeiros. Esse fazer artístico que congrega boa parte da população dialogava com o desenho de mundo grotesco, com o simiesco das relações, com os contrastes entre essência e a aparência, reproduzindo o indivíduo, sua cultura alienada e os costumes do país grotescamente. "E eu há muito tempo que não via tantos casos notáveis da nossa triste humanidade. Estamos como que diante de vitrinas de um museu de casos de patologia social" (BARRETO, 2010, p. 210).

As obras do intelectual se aproximavam bastante da coloquialidade, totalmente contrárias ao fazer literário que antecedia ao escritor e que prevalecia em sua época, inaugurando um novo olhar para a literatura: "no nível da linguagem, a consciência da ruptura se esboça já a partir de 1904: em que nível situar a linguagem, como libertá-la das condições impostas dos modelos consagrados, como transformá-la em instrumento capaz de aproximar historicamente da realidade em mudança" (PRADO, 1976, p. 17-18). Tais escritos, limpos do purismo linguístico que acompanhava as escrituras brasileiras, flagravam os costumes invertidos, o desencontro entre o público e o particular, o oficial 
e o não oficial. As palavras ferinas destronavam, rebaixavam, criticavam o modo de vida corrupto e alienado do povo. "Sua ficção faz-se essencialmente de caricaturas e ironias" (SEVCENKO, 2003, p. 238). O conceito de dialogismo tecido sob a pena de Mikhail Bakhtin (2010) aponta os discursos da vida como inseparáveis do discurso da arte. Em outras palavras, a escritura literária é uma tentativa arriscada dos autores de representação da vida, sendo quase que impossível que um autor se desvencilhe do momento histórico em que se encontra inserido.

O primeiro romance de Barreto, Recordações do escrivão Isaías Caminha, sofreu um grande embargo da crítica da época. Tais posicionamentos negativos voltados para a obra do escritor estavam relacionados, em especial, para uma escrita que, além de ser vista como um panfleto crítico ao jornalismo da época, aparentava-se a uma biografia do escritor. Essas palavras que foram repetidas por longos anos, mesmo após a morte do escritor e a ascensão da crítica literária brasileira depois dos anos de 1930, desconheciam, de certo modo, o valor de literatura ao qual Lima Barreto se inclinava: Balzac, Dostoiévski, Eça de Queiroz, entre outros ficcionistas da pena realista, que eram vistos como sinônimos de uma arte de representação da vida social do povo que compunham o popular. A descrição da vida carnavalizada do homem, fora dos elementos oficiais, assim como das miserabilidades humanas, era vista como o maior modelo artístico. Logo, trazemos George Lukács para dialogar com esse pensamento, quando o húngaro aponta a existência artística como uma necessidade da vida; a arte vem em resposta às contradições existentes na vida corrente do homem, passando a figurar para o artista como uma forma de superação dos problemas mundanos.

Dessa forma, a criação artística de Lima Barreto perpassa temas voltados, em especial, para o cotidiano do homem comum, unidos por uma linguagem envolta na coloquialidade; seus discursos são distendidos sob a voz de personagens, às vezes, satíricos, outras vezes, de narradores irônicos. Esses sujeitos reproduziam as linguagens alheias, marcados pelo jogo de expressões jocosas que visavam ao rebaixamento, colocando na mesma categoria o grande "intelectual" e o mercador, o grande sujeito com o de baixas posições. Quando o escritor deu voz às minorias que antes estavam esquecidas, como é o caso dos pobres e dos negros, pretendia ressignificar o conceito de arte de seu tempo. Consoante Prado: 
A primeira atitude denuncia, nos quadros dominantes, a ausência de um papel específico da literatura; o que se questiona é o próprio sentido do fato literário, de um lado carente de expressão no contexto histórico em que se insere e, de outro, inutilizado em sua essência - definido como acessório, função secundária e inoperante comprometida unicamente com a emoção estética. (PRADO, 1976, p. 34).

Para Lima Barreto, por sua vez, "a opção pela literatura é uma opção moral consciente e irreversível” (PRADO, 1976, p. 34). O Brasil utópico, os valores atrasados e escritores e jornalistas que não denunciavam os problemas do país foram os principais focos de sátira do autor, mesclando a atitude teatral da vida dos profissionais, com a seriedade das contradições sociais. "A maior parte do seu humor tem como objeto as coisas do Brasil, o Brasil injusto, até mesmo ilógico, é retratado com ironia fina e sátira nervosa que provocam, não um riso espontâneo e alegre, mas um sorriso recheado de dores latentes" (GERMANO, 2000, p. 26). Os narradores cômicos descrevem os personagens, na maioria dos casos, por meio de seus defeitos, de suas fraquezas, reafirmando a inexistência do herói exaltado, sublime e sem defeitos que a literatura brasileira ainda pôde aplaudir, particularmente, no momento literário denominado Romantismo. "As que há, ou são de uns ignorantes literatos que não viram uma granada em uma pedra, ali, da pedreira no rio Comprido, ou são formados por uns médicos faladores que têm pretensão de literatos" (BARRETO, 2010, p. 190). Tais descrições são o que levam muitas narrativas com teor grotesco e triste se tornarem grandes exemplos de comicidade. Mikhail Bakhtin (2014) ressalta:

O direito de falar parodiando, de não ser literal, de não ser o próprio indivíduo; o direito de conduzir a vida como uma comédia e as pessoas como atores; o direito de arrancar as máscaras dos outros, finalmente, o direito de tornar pública a vida privada com todos os seus segredos mais íntimos. (p. 278).

O parodiar da vida, como é visível nas escritas de Barreto, vale-se na expressão de Bakhtin, apontando a liberdade discursiva e ressaltando a carnavalização das imagens da vida em que o poder não paira, e o sujeito pode se expor integral. A proximidade estabelecida nas festas do carnaval é retomada, e as fronteiras entre a pessoas diminuem. Tirar um sujeito das vestes oficiais é humanizá-lo; a busca de Lima Barreto se achava na primazia de encontrar a essência humana. Porque tal estilística? Talvez um descompromisso social visto, tanto da política de seu tempo, marcada pelo fim do Império e da escravidão e a ascensão da República, quanto pelas vozes dos diversos escritores e jornalistas que marcavam a época e não descreviam esses problemas. Mudou-se de regime político, mas a mentalidade da população se matinha sob a luz do regime anterior. Essa 
permanência do antigo no novo tornara-se uma das principais fontes das escrituras do cronista.

A arte que permeava o espaço literário no limiar do século $\mathrm{XX}$, na perspectiva do escritor, havia perdido a essência. O realismo que já estava patente em fins do século XIX foi superado por obras contaminadas por um espírito simbólico e de extremo apego à gramática, formas escriturais que não comunicavam mais, que não alcançavam o leitor pouco letrado. Percebendo o grande número de analfabetos no início do século, Lima Barreto reconhecia a ineficácia desse estilo de fazer artístico. O Destino da Literatura, artigo em que o intelectual expõe os problemas da literatura de seu tempo e aponta caminhos para o que ele considera o verdadeiro dever artístico, sinaliza e reforça o estilo militante que persegue seus discursos, merecendo atenção de um importante escritor da nossa literatura: Monteiro Lobato. "De Lima Barreto não é exagero dizer que lançou entre nós uma fórmula nova de romance. O romance de crítica social sem doutrinarismo dogmático" (LOBATO, 1997, p. 425).

Os sistemas literários expostos à sátira do escritor eram o Simbolismo e o Parnasianismo. Uma possível justificativa é dada pela pesquisadora Zelia Nolasco Freire. Freire salienta que as críticas ao simbolismo surgiam porque esse modelo procurava reproduzir imagens que não cabiam mais à sociedade brasileira, criando obras artificiais; por outro lado, os parnasianos estavam atentos à forma e à sintaxe em detrimento do conteúdo social em vigor. "Se nos parnasianos - o afastamento da realidade - ocorria através do culto exacerbado da forma, nos simbolistas era através do conteúdo" (FREIRE, 2005, p. 38). A jocosa exposição da figura do literato tem tanto o intuito de mudança das práticas desses sujeitos sociais, quanto a necessidade de comunicar à população o alienado e distante mundo pelos quais vagavam. No conto "Harakashy e as escolas de Java”, um excerto reforça a atitude teatral que Barreto descrevia a literatura de sua época: "A literatura desses doutores e cirurgiões é das mais estimadas naquelas terras; e isto, por dois motivos: porque é feita por doutores e porque ninguém a lê e entende" (BARRETO, 2010, p. 154).

Para Vladimir Propp (1992), a “paródia é um dos instrumentos mais poderosos de sátira social” (p.87). Lima Barreto, por seu turno, utilizou amplamente o recurso paródico em suas escrituras, destronando os intelectuais das letras brasileiras em busca da revelação de seu atraso. Ainda nas palavras do pensador russo, "parodia-se, na verdade, o estilo individual de um escritor, mas esse estilo individual é por outro lado a 
manifestação de uma corrente determinada à qual pertence o escritor e justamente essa corrente é ridicularizada do ponto de vista da estética" (p. 87). No excerto acima, quando Barreto expõe as características negativas das personagens, está se direcionando às correntes de pensamento que preponderavam na época e o apego ao formalismo da língua.

Gilles Deleuze (1997), pensando literatura e vida, ressalta que de maneira alguma a literatura deve representar a vida; entretanto, mesmo com essa forma de pensar que é contrária à que estamos desenhando aqui, ele resgata um aspecto muito importante para o significado da arte literária, quando vem traçando uma postura de escritura enquanto devir. Assemelhando o mundo a uma doença, o pensador aponta que a literatura seria exatamente a cura para o mundo, seria o resgate do devir humano. "A saúde como literatura, como escrita, consiste em inventar um povo que falta" (DELEUZE, 1997, p. 14). A literatura é delírio para o pensador, mas quando alcança os povos menores, ela se torna remédio, torna-se cura, saúde. Esse era o grande objetivo das obras barreteanas, mostrar para o mundo a vida daqueles que não existiam, ou mostrar para essa parcela da sociedade apagada o mundo que elas desconheciam. Para o escritor, o conhecimento e a leitura eram a grande fórmula do sujeito pobre e negro ter consciência do mundo à sua volta e dos problemas. A fuga à alienação humana, como bem aponta Georges Lukács, destaca-se como a forma de superação do mundo fetichizado, e a obra de arte porta-se como instrumento profícuo para tal investidura. Da mesma forma, tanto público quanto autor utilizam-se do espaço da arte enquanto refúgio de um mundo fetichizado e alienado.

Na edição de Histórias e Sonhos, livro de contos do autor publicado pela primeira vez no ano de 1920, o leitor é confrontado inicialmente com uma narrativa chamada Amplius, na qual se relatava a história de uma carta que recebeu em razão da publicação de Triste Fim de Policarpo Quaresma. A narrativa inicia com a descrição do narrador respondendo a carta. Na correspondência, este diz se incomodar com o questionamento do anônimo em relação às referências que sua arte não se compara com as gregas. Em resposta, ele assegura que a arte grega não dá conta do cotidiano contemporâneo. "Ela não nos pode mais falar, talvez nem mesmo balbuciar, e o que nos tinha a dar, já nos deu e vive em nós inconscientemente" (BARRETO, 2008, p. 09). Por sua vez, o que é mais curioso nessa escritura é a atenção dedicada a um possível estilo de literatura que deveria preponderar na sociedade contemporânea, ou seja:

Parece-me que o nosso dever de escritores sinceros e honestos é deixar de lado todas as velhas regras, toda a disciplina exterior dos gêneros e aproveitar de 
cada um deles o que puder e procurar, conforme a inspiração própria, para tentar reformar certas usanças, sugerir dúvidas, levantar julgamentos adormecidos, difundir as nossas grandes e altas emoções em face do mundo e do sofrimento dos homens, para soldar, ligar a humanidade em uma maior, em que caibam todas, pela revelação das almas individuais e de que elas tem em comum e dependente entre si. (BARRETO, 2008, p. 10)

Aqui ficam patentes duas formas de representação opostas. Se as literaturas da época de Lima Barreto estavam em protesto exatamente contra as escrituras que as antecederam, procurando uma forma diferente de inscrição discursiva, tirando da obra de arte essa necessidade de representação da vida, a obra do escritor carioca, em contrapartida, buscava zelar por essa forma de olhar estético. A construção imagética do escritor Coelho Neto, uma das figuras mais aplaudidas pela população no período, tornouse uma das maiores caricaturas desenhada sob a pena de Lima Barreto; tal desprezo explica-se pelas diversas funções que o escritor exercia no cenário político e literário brasileiro. O pensamento de Barreto nos leva a dialogar com o pensamento lukacsiano e a avaliar o fetiche literário: Coelho Neto em um único ano produziu nove livros; essa práxis escritural põe em xeque a qualidade dessas produções e encaminha a um pensamento artístico vinculado à recepção dos anseios sociais. A arte de fetiche não está preocupada com a qualidade técnica, mas com a quantidade de produção e vendas. $\mathrm{O}$ movimento artístico ao qual Barreto se filiou, que ainda pode contar com a presença de Euclides da Cunha, elegia a obra de arte como forma de desalienação humana, de reprodução dos problemas e das misérias sociais de um povo.

Vale passar pelas reflexões tecidas no livro de Hipócrates (460 a.C. - 370 a. C.) Sobre o riso e a loucura para tentar, de alguma forma, fundamentar o estilo de riso que percorre as páginas narrativas de Lima Barreto. Hipócrates foi chamado à cidade de Abdela para curar Demócrito, cidadão que possuía uma boa reputação perante a sociedade, mas que, segundo as palavras de um emissário da pequena cidade, encontravase em estado de demência:

Na verdade ele ria de tudo e de todos, e esse era o motivo de ser classificado como louco, ou como filósofo risonho. Nota-se o efeito nocivo de seu comportamento, posto que Demócrito demonstrava desprezo pela humanidade, motivo pelo qual se tornou insuportável a todos. (CAMPOS, apud HIPÓCRATES, 2011, p. 22)

O médico, mesmo vendo o grande alarde da população e percebendo que a loucura estava na sociedade, vai em socorro do lugar. "Desejo curar a doença da cidade, a qual se tornou doente devido a um só homem, Demócrito" (HIPÓCRATES, 2011, p. 41). A 
chegar ao local, comprova sua premissa constatando que Demócrito realmente não estava louco. Eis a causa: quando ele passou a rir de toda a sociedade, desde as maiores miserabilidades humanas, é porque percebeu a natureza doente do homem, a loucura humana, marcada pela ganância e os vícios sociais. Afirma-se no livro:

Dessas coisas eu rio mesmo, ó homens insensatos, pois é justo o seu sofrimento: ganância, desejos exagerados, inimizades, emboscadas, traições, invejas, expondo-se sempre em infinitas dificuldades maléficas, pois não há pior ignorância que duas mentes insensatas conspirando danos mútuos. A virtude [arete] para esses homens é algo inferior, pois agem como amantes da mentira, dos prazeres superficiais, antepondo-se aos costumes. Meu riso condena a falta de discernimento dos que não partilham nem da visão nem da audição, pois os sentidos humanos só fazem brilhar a verdade por meio da reflexão, a partir da qual antecipam o presente e o futuro. (HIPÓCRATES, 2011, p. 57-58).

Do fragmento acima, deduz-se que o riso exagerado possui a essência do trágico, das tristezas que demarcam a vida, sua ganância, a irracionalidade que percorre as ações sociais. O riso presente nas obras de Lima Barreto é o riso humano, é o riso de Demócrito que reconhece os problemas da natureza humana e não tem outro fundamento para superálos, restando como meio de escape o sorriso. A atitude cômica, nesse sentido, não está assentada em um cidadão em si, mas, quando aparece, representa toda uma sociedade, um povo, ou mesmo a própria espécie humana, uma vez que a característica que une todos os homens é exatamente o riso, aspecto inerente ao homem e casulo para fuga aos problemas humanos.

Vaticinou Nietzsche (2001): “A verdade é a verdade do rebanho" (p. 06). Se Lima Barreto procurou ao longo de sua vida construir uma arte caricata estabelecendo um grande hiato entre seus pressupostos e o de seus contemporâneos, tornou-se apenas uma ovelha desgarrada de seu rebanho e suas palavras serem tidas enquanto mentira. $\mathrm{O}$ carioca recebeu, durante sua existência, poucas palavras de conforto e rara ajuda para se ver como escritor representativo. Mesmo com um grande número de escritos, que incluem romances, crônicas e contos, entre outros, a maioria deveu-se à própria busca do escritor que, com os poucos ganhos, pagava pela publicação de seus livros. Escritor marginal, sim, mas apenas na época de escritura de suas obras, pois o reconhecimento póstumo veio aos poucos, e a contemporaneidade lê - e lê Lima Barreto -, procura o autor em cada linha transcrita e o aclama como grande romancista e influenciador das manifestações de literaturas que passaram a ser chamadas de modernistas. 


\subsection{Sátira e ironia nos romances de Lima Barreto}

Mikhail Bakhtin sustenta que "Nós não vemos quem a personagem é, mas de que modo ela toma consciência de si mesma, a nossa visão artística não se acha diante da realidade da personagem mas diante da função pura de tomada de consciência dessa realidade pela própria personagem" (BAKHTIN, 2010, p. 54). Esse traço de conhecimento da personagem por meio da tomada de consciência de seu mundo é bem exemplificado em Recordações do Escrivão Isaías Caminha (1909), primeiro romance de Lima Barreto. Narrado em primeira pessoa, esse romance nos parece mais um testemunho do que a história de um sujeito. A tomada de consciência do protagonista perante o mundo se afigura a um romance de tese, para dialogarmos com a crítica de Osman Lins, em que, como um narrador, na maior parte da trama, distanciado, faz uma análise crítica do mundo em que habita e de si mesmo, de sua posição perante aquele mundo e o que aquele mundo figurou para ele após a saída do estabelecimento jornalístico onde trabalhava.

O limiar do enredo surge com a exposição do narrador sobre o conhecimento da família, desprezando constantemente a mãe e os parentes maternos, Isaías Caminha se põe em um plano superior do que aqueles. Entretanto, o espírito de superioridade, fruto do conhecimento que nasceu na mesma data da vitória de Napoleão, na Batalha de Morengo, insere o jovem no mundo das ilusões. "Houve na minha alma um tumultuar de desejos, de aspirações indefinidas. Para mim era como se o mundo me estivesse esperando para continuar a evoluir" (BARRETO, 2012, p. 16) A superioridade do rapaz, que passou a distanciar e a sentir-se diferente das outras pessoas, demonstra o primeiro contraste do espírito humano e nos conduz ao riso pela ingenuidade da personagem romanesca. Menino negro e pobre, Isaías Caminha, conhecendo as dificuldades de se viver em uma grande cidade, é movido pela superioridade. Ao ver que um colega que chegou a lecionar, conseguiu se formar, descobre que pode muito mais, pois é melhor que aquele. A cor no meio dos dele era quase que desconhecida, e a vida na cidade grande parece se tornar fácil.

Essa marca que abre a narrativa começa a perseguir o relato tragicômico da personagem: a comicidade se alastra com o desenho caricatural do jovem imbuído de sonhos de títulos e com a sombria descrição da personalidade humana que procura o título visando à corrupção e à maneira de livrar-se das possíveis punições angariadas pelo ato 
impróprio. "Quantas prerrogativas, quantos direitos especiais, quantos privilégios, esse título dava! Podia ter dois e mais empregos apesar da Constituição; teria direito à prisão especial e não precisava saber nada. Bastava o diploma” (BARRETO, 2012, p. 23). Além do mais, o diploma se averiguava como a fórmula da vida humana - sem necessidades de conhecimento o homem subia os degraus. Assim, o pensamento ilusório do jovem se conduzia para a ilusão de uma vida fácil na grande capital. A figura do doutor separava os homens em castas diversas, tornando impossível o diálogo com a outra. Entretanto, rapidamente será derrubado pelas circunstâncias sociais do novo espaço - o preconceito que desconhecia no subúrbio onde morava o esperava.

A narrativa culmina com a entrada do jovem no estabelecimento jornalístico. A imprensa no limiar do século XX era o principal meio de os jovens escritores entrarem no mundo literário, sendo o próprio autor dessa obra um grande exemplo, como atesta Francisco de Assis Barbosa (2002): "Julgava então que era possível contemporizar, servindo-se da imprensa burguesa como único meio para se tornar conhecido e fazer publicar os seus livros" (p. 173). É sabido que Barreto, no início de sua carreira, fez de um dos maiores jornais do momento, o Correio da Manhã, seu recinto de aprendizagem. As palavras rascunhadas em Isaías Caminha, as memórias trágicas do espaço jornalístico parecem ser retiradas do tempo que esteve na redação, levando a crítica a reconhecer em alguns personagens romanescos os trabalhadores do Correio da Manhã.

O Isaías do ambiente jornalístico não é mais o menino ingênuo que deixou sua casa no subúrbio e conviveu com grandes problemas até conseguir emprego no jornal, mas era um grande observador. Com a nova função que passa a exercer, contrastando o lugar de entregador de papéis com a de observador, constrói um quadro grotesco do ambiente jornalístico. O espaço muda de figuração, as máscaras que antes se apresentavam ao público, na figura dos jornalistas, são retiradas e pode-se encontrar o homem em sua essência fora dos elementos elevados e do heroísmo cotidiano. A sátira menipeia, como recurso ideológico, se alia às descrições de rebaixamento, conduzindo ao riso como meio de desvendamento da natureza humana. A figura de Ricardo Loberant, o diretor, sujeito temido por todos que trabalhavam para ele, é realizada fora dos elementos elevados: "Era um homem temido, temido pelos fortes, pela gente mais poderosa do Brasil, ministros, senadores, capitalistas; mas em quem, com espanto, notei uma falta de firmeza, de certa segurança de gestos e olhar, própria dos vencedores” (BARRETO, 2012, p. 100). A humanização do homem o afasta da atitude teatral cotidiana, o equaliza as 
outras pessoas. A narração posterior da grande personalidade em um bordel, traindo sua esposa, é apenas a refiguração do indivíduo com todos os seus defeitos, vestido com as vestes humanas e unificando-se aos demais. A figura sublime do grande homem contrasta com a vulgaridade cotidiana simbolizada pelo prostíbulo.

A ideia social do jornalista como portador de uma aura superior é desmontada. Por meio da sátira os acontecimentos são estilizados e exagerados. Esse aumento do fato é que provoca o riso e convida o leitor a pensar nas práticas adotadas; a proximidade narrativa com a vida, a capacidade de levar o leitor a se reconhecer no que está sendo narrado é que se afigura o ideal de literatura barreteana - para o escritor a arte deveria ser uma resposta ao mundo. O riso do narrador Isaías Caminha surge ao perceber uma falta de aliança entre o imaginado e o concreto: as pessoas viam nos jornalistas grandes homens, e o narrador romanesco constatou suas fragilidades, seus defeitos - a partir daquele momento, os deuses jornalistas desceram à terra, humanizaram-se. A obra artística, nesse momento, porta-se como grande meio de denúncia social. Os homens importantes da sociedade, admirados e aclamados pela população, passaram a ser retratados dentro de suas fraquezas, dos problemas nos momentos de escritura de suas reportagens; as dificuldades da redação, a forma como forjavam mais notícias, o grande poder que mantinham perante os governantes - todos esses fatores são levados ao povo de forma sarcástica e risível:

\footnotetext{
Nada há tão parecido como o pirata antigo e o jornalista moderno: a mesma fraqueza de meios, servida por uma coragem de salteador; conhecimentos elementares do instrumento de quem lançam mão e um olhar seguro, uma adivinhação, um faro para achar a presa e uma insensibilidade, uma ausência de senso moral a toda a prova... e assim dominam tudo, aterram, fazem que todas as manifestações de nossa vida coletiva dependam do assentimento e da sua aprovação. Todos nós temos que nos submeter a eles, adulá-los, chamá-los gênios, embora intimamente os sintamos ignorantes, parvos, imorais e bestas. (BARRETO, 2012, p. 94-95)
}

A aura do ambiente sério de trabalho é desconstruída por meio da narração cômica: a comparação com o pirata, qualidades negativas dos jornalistas levam ao riso; além do mais, a denúncia está feita quando sinaliza que as pessoas são obrigadas a se submeterem aos seus deleites: desse modo o local é destronado, surgindo, assim, um mundo grotesco por meio do discurso alegre, levando o leitor ao riso. As gargalhadas mantidas em cada descrição encaminham para a tragicidade e para a ilusão que o espaço jornalístico proporcionava ao homem de letras, em sua atitude grotesca em ver fama e posição social escrevendo más linhas para um noticiário diário. Dizia o narrador: "Eu não 
sou literato, detesto com toda a paixão essa espécie de animal" (BARRETO, 2012, p. 73). O conhecimento - base de tudo - era desprezado, as rasas palavras descreviam o necessário, os adjetivos de bajulamento a quem pertencia o poder eram a chave do sucesso. E o riso satírico ia sendo armado, os costumes ridicularizados, rebaixando as mais aclamadas figuras do meio social - os jornalistas - comandados principalmente por escritores do período, o que afastava cada vez mais o escritor-protagonista do reconhecimento que tanto lutava.

\begin{abstract}
Esperava o doutor Loberant, mas entrou o fino, o elegante, o diplomático, o macio Frederico Lourenço do Couto, com a sua linda barba perfumada e seu grande queixo erguido e atirado para adiante como um aríete de couraçado. Vinha todo perfumado, de olhar lustroso, desprendendo essências, com o peitinho da camisa a brilhar imaculadamente e um grande botão de coral ao centro, rodeado de brilhantes. (BARRETO, 2012, p. 107-108).
\end{abstract}

Destacamos, em particular, na citação acima o emprego irônico de descrição da personagem. As características apontadas são as qualidades relegadas ao jornalista que está em uma constante procura em embelezar a vida. A ironia à beleza da vida se reporta em vários momentos à narração, procurando contrastar a beleza dos papéis com a miserabilidade da vida, o que está expresso nos jornais, e o que as ruas denunciam. Ainda para ilustrar o quadro letárgico dos homens de letras, apontamos o trágico relato da personagem Floc, o renomado crítico literário. A tragicidade surge da figuração da personagem enquanto um dos maiores escritores do jornal; mas, contrariamente ao que se remete ao sujeito que trabalha com a língua, chega um momento que o leitor apenas reconhece um homem frustrado por não conseguir escrever nada: "Floc esteve um instante com a cabeça entre as mãos, parado, tragicamente silencioso; depois, levantouse firmemente, dirigiu-se muito hirto e muito alto para um compartimento próximo. Houve um estampido e ruído de um corpo cair" (BARRETO, 2012, p. 192). Floc se torna uma grande metáfora da ineficácia da linguagem da gramática, construindo símbolos que nada comunicam, chegando ao ato final da grotesca morte. Esse fato também pode ser visto como uma grande alegoria de uma gramática que não se comunica mais com o povo. Osman Lins destaca que essa narrativa de Barreto inaugura no romance brasileiro, ou seja, a narrativa da incomunicabilidade, em que as personagens romanescas nunca se encontram. A narrativa de Isaías na redação do jornal delineia, quase completamente, como um protagonista distanciado, sem se comunicar com os demais integrantes do espaço. 
A sátira, que ora era dirigida para os demais integrantes da narrativa, volta-se contra o próprio protagonista. Mesmo sofrendo em momentos de chegada na cidade grande, vivenciando todos os atropelos que a carreira jornalística propiciava, esse não foi o motivo que o levou a ser diferente. Ao ter o poder nas mãos, atropelou o outro, chantageou para conseguir posições renomadas no ambiente de trabalho. Enfim, esqueceu a família e passou a viver do bem-estar que aquela rápida fama poderia fornecer. $\mathrm{O}$ retrato do novo homem social é uma crítica à figura humana e procura descortinar uma sociedade grotesca, a partir da imagem de um homem negro, conseguindo uma posição considerável dentro de um ambiente de trabalho e apontando para o riso - das ambições, da necessidade de fama - que não passa, por muito, de uma luta constante por sobrevivência. Vejamos a seguir:

Depois de empregado no jornal, pouco the escrevi. Sabia-a muito doente, arrastando a vida com esforço. Não me preocupava... O ditos do Floc, as pilhérias de Losque, as sentenças do sábio Oliveira, tinham feito chegar a mim uma espécie de vergonha pelo meu nascimento, e esse vexame me veio diminuir em muito a amizade e a ternura com que sempre envolvi a sua lembrança. (BARRETO, 2012, p. 175).

A ironia à humanidade fica evidente para o leitor. A tese do protagonista, distendida por meio de suas memórias, vai se delineando. Transformado em imagem artística, o plano filosófico da vida retira tudo o que integrava o particular e o expõe em praça pública - símbolo de liberdade de expressão e carnavalização. A ambivalência da praça pública aproxima os sujeitos, coloca-os em condições do "livre contato familiar": somos todos iguais, estamos passíveis dos mesmos problemas - Loberant, homem mais importante da sociedade carioca é chantageado; Floc, o maior conhecedor da gramática vista como símbolo da língua - não consegue se comunicar por meio da linguagem; Isaías Caminha, negro que nasceu em um subúrbio carioca se torna jornalista, é elogiado pela perspicácia no trabalho e chantageia tão bem quanto o grande dono do jornal.

A tese de igualdade humana parece se unificar no final da narrativa. E a luta do herói contra a determinação social se consagra na representação do homem por meio do riso; espaço onde as diferenças são deixadas de lado em nome da igualdade. Quando Schopenhauer fala da indisociabilidade entre o humano e o riso, destacando que são as misérias próprias da vida do homem que não o deixa se afastar do riso, reconhecemos que o herói romanesco pode ser lido apenas como uma alegoria desse espaço de vícios - a vida - tão cômico que não poderíamos deixar de rir com ele, de compactuar com as suas 
ilusões perdidas, porque são as ilusões de todo um povo, viver sob o prisma da grandeza e da superioridade do outro.

\begin{abstract}
Como de hábito, Policarpo Quaresma, mais conhecido por Major Quaresma, bateu em casa às quatro e quinze da tarde. Havia mais de vinte anos que isso acontecia. Saindo do Arsenal de Guerra, onde era subsecretário, bongava pelas confeitarias algumas frutas, comprava um queijo, às vezes, e sempre o pão da padaria francesa. Não gastava nesses passos nem mesmo uma hora, de forma que, às três e quarenta, por aí assim, tomava o bonde, sem erro de um minuto, ia pisar a soleira da porta de sua casa, numa rua afastada de São Januário, bem exatamente às quatro e quinze, como se fosse a aparição de um astro, um eclipse, enfim um fenômeno matematicamente determinado, previsto e predito. A vizinhança já lhe conhecia os hábitos e tanto que, na casa do Capitão Cláudio, onde era costume jantar-se aí pelas quatro e meia, logo que o viam passar, a dona gritava à criada: "Alice, olha que são horas; o Major Quaresma já passou." (BARRETO, 2008, p. 09).
\end{abstract}

É dessa forma que o leitor confronta a narrativa Triste Fim de Policarpo Quaresma (1911), uma das obras consideradas pela crítica como a mais bem-sucedida do escritor carioca. Nessa chave de abertura romanesca já é possível perceber algumas características que vão entremear a narrativa e que servem enquanto alegoria dos fatos concorrentes. O Major tinha uma rotina metódica: chegava todos os dias no mesmo horário; a ironia do narrador em assemelhá-lo a um astro, assim como na narração da vizinha que olhava as horas a partir da chegada do escriturário, encaminham para a comicidade que vai preencher as páginas narrativas. Esses elementos são essenciais para a compreensão do enredo romanesco e para o contraste que vai se estabelecendo ao longo da escritura, traços fundamentais para a composição imagética grotesca do protagonista. "O romance narra a história tragicômica de um excêntrico funcionário público do Arsenal de Guerra, humanista convicto, no fundo quase pacifista, que dedica toda sua vida à 'grandeza e emancipação da Pátria"' (ZILLY, 2003, p. 56).

Considerado uma grande paródia de Dom Quixote de La Mancha, de Miguel de Cervantes, a narrativa porta-se como uma crítica ao patriotismo do homem, que passa a viver de hábitos deslocados do seu tempo. Desde o título, ambas as narrativas apresentam contrastes: a utilização de "Dom" no nome de Quixote é uma ironia ao título de cavaleiro que quer receber; do mesmo modo, o emprego de "Major" não corresponde ao cargo de subsecretário que mantinha, na realidade faz referência apenas à vida metódica de Quaresma. O amor aos livros também é outro fator que une as obras: Dom Quixote é guiado pelos romances de Cavalaria: "ele engolfou-se tanto em sua leitura, que lendo passava as noites em claro, e os dias em turvo; assim, do pouco dormir e do muito ler, lhe 
secou o cérebro de modo que lhe veio perder o juízo" (CERVANTES, 2010, p. 54). Quaresma ensandeceu pela leitura dos livros da cultura brasileira: "Devia ser proibido disse Genelício - a quem não possuísse um título 'acadêmico' ter livros. Evitavam-se assim essas desgraças" (BARRETO, 2008, p. 55). A loucura de ambas as personagens é vista pelo apego aos livros e o diálogo intertextual que Barreto estabelece com a narrativa cervantina fica cada vez mais evidente.

Além dessa referência direta à obra cervantina, Barreto trilha outras duas importantes escrituras que servem de profunda importância para a composição de sua personagem: Madame Bovary (Gustave Flaubert) e Cândido (Voltaire). Os ideais de vida desses personagens se tornam protótipos do protagonista de Lima Barreto, tanto no apego aos livros quanto nos ideais ilusórios em que vivem. O bovarismo, caso frequente no limiar do século XX, aponta como uma grande utopia a partir da qual o sujeito se via alienado num país que não existia, vivendo enquanto um pária social em um local estranho. De forma irônica, o enredo vai sendo engendrado, a zombaria preenche boa parte da escritura, atirando principalmente às atitudes do Major. Além do mais, é importante trazer a imagem da assertiva de Osman Lins com referência à narrativa da incomunicabilidade para reforçar o protótipo do herói: Quaresma, mesmo estando em contato com outras poucas pessoas, não consegue se comunicar com elas, visto que suas atitudes o situam em outro momento, o fazem incompreensível, não havendo a concretização dialógica.

Escrito em terceira pessoa, o romance se utiliza de mais um narrador ideólogo; dessa vez a premissa da escritura é o desapego do brasileiro com sua cultura: por meio do discurso irônico o ideólogo apresenta a vida tragicômica de Policarpo Quaresma "homem pequeno, magro, que usava pince-nez" (BARRETO, 2008, p. 10), o qual se provém de alguns fatos para dar consistência à sua tese: aprender tocar a violão, estudar o tupi guarani, vestir roupas a partir apenas de artefatos brasileiros, comer apenas alimentos brasileiros, trabalhar na agricultura e ir para a guerra para salvar o país são marcas descritivas que levarão o major a ser considerado louco e que despertarão o riso do leitor quanto à inadequação do Major às reais situações vivenciadas pelo país nesse contexto histórico. O final é consagrado com o assassinato do protagonista e a comprovação da tese do ideólogo. Tais atitudes estão diretamente ligadas a uma espécie de afastamento dos livros, como assinala Sevcenko (2003): 
Ela implicava sobretudo uma mudança na forma de olhar, exigindo que se saísse das páginas dos livros e da cultura letrada, das tribunas, das bibliotecas e dos gabinetes, para um contato direto com a realidade do país, sua natureza, sua gente, seus campos, suas cidades. (p. 213).

O desejo de aprender a tocar violão, no primeiro capítulo da obra, contrasta com a seriedade da personagem. "Um homem tão sério metido nessas malandragens!" (BARRETO, 2008, p. 10). A presença do cantor de modinhas desenhado desde as linhas romanescas iniciais denuncia na estrutura narrativa uma tentativa de conservação das coisas locais, da cultura do país que se via totalmente alienado aos prazeres de fora. A narração crítica se contrasta com a atitude teatral da população, vigiando o Major em sua diversão: "E, na mesma tarde, uma das mais lindas vizinhas do major convidou uma amiga, e ambas levaram um tempo perdido, de cá para lá, a palmilhar o passeio, esticando a cabeça, quando passavam diante da janela aberta do esquisito subsecretário" (BARRETO, 2008, p. 10). O lirismo da descrição da beleza angelical da moça se contrapõe ao grotesco ato do major e ao susto da população que via tais leviandades, conduzindo para a comicidade e apontando aspecto irônico do romance.

Ricardo Coração dos Outros, professor de violão e amigo de Policarpo, é apenas a metáfora da necessidade de o homem brasileiro manter seus costumes, viver sobre os hábitos locais, fora de um olhar que via no estrangeiro o benefício de tudo. A "limpeza" cultural pela qual o Brasil procurou realizar no início do século XX desprezava completamente o cantor de modinhas que, como assinala Sevcenko, tornou-se sinônimo de malandragem, como mostra o fragmento abaixo:

A reação contra a serenata é centrada no instrumento que a simboliza: o violão. Sendo por excelência o instrumento popular, o acompanhante indispensável das "modinhas" e presença constante nas rodas de estudantes boêmios, o violão passou a significar, por si só, um sinônimo de vadiagem. (SEVCENKO, 2003, p. 46).

A defesa que o herói sustenta em favor das modinhas é altamente clara, deixando patente a posição ideológica do escritor. "A modinha é a mais alta expressão da poesia nacional e o violão é o instrumento que ela pede" (BARRETO, 2008, p. 12). Além do mais, a busca por músicas escritas apenas em solo brasileiro reforça tanto a atitude patriótica do Major, quanto a comprovação de que o brasileiro está esquecendo suas raízes folclóricas, uma vez que se tem dificuldade de encontrar canções originárias brasileiras. A atitude de Quaresma passa a ser vista como retorno a um passado que deve ser esquecido, violando, de certo modo, uma ordem imposta socialmente. Propp (1992) assinala que a transgressão a certo hábitos sociais "é ao mesmo tempo a transgressão de 
certos ideais coletivos ou normas de vida", ou seja, é percebida como defeito, e a descoberta dele, como também nos outros casos, suscita o riso. Essa atitude preliminar de Policarpo conduz tanto ao riso, quanto à insatisfação dos mantedores daquela ordem que estava sendo transgredida.

O romance, à luz da popularidade do cantor de modinhas, invade a alta sociedade de sua época e, em poucas páginas, elaborado seu retrato grotesco e carnavalizado: "É uma alta sociedade muito especial e que só é alta nos subúrbios" (BARRETO, 2008, p. 18). Tais descrições reforçam a espetacularização social que o escritor procurava traçar de sua pátria; os integrantes do poder sempre foram de atenção e exposição jocosa de Lima Barreto: "Porque o orgulho da aristocracia suburbana está em ter todo o dia jantar e almoço, muito feijão, muita carne-seca, muito ensopado - aí, julga ela, é que está a pedra de toque da nobreza, da alta linha, da distinção" (BARRETO, 2008, p. 18). O comer de todos os dias era a riqueza do povo, e era a que os outros, que não tinham a fartura, almejavam; eram os grandes banquetes rabelaisianos que estavam sendo relembrados, apontados e refigurados por meio de um povo esfomeado que fugia todos os dias da pobreza e que agradecia por sua eterna nobreza. Além do mais, a figura do general com seus anseios medíocres se torna alvo da pena limabarretiana:

O altissonante título de general, que lembrava coisas sobre-humana dos Césares, dos Turennes e dos Gustavos Adolfos, ficava mal naquele homem plácido, medíocre, bonachão, cuja única preocupação era casar as cinco filhas e arranjar pistolões para fazer passar os filhos nos exames do Colégio Militar. (BARRETO, 2008, p. 12).

O rebaixamento da personagem mediante os qualificativos negativos aponta a sátira aos costumes e desvenda as relações de interesse da alta sociedade, retirando a máscara do grande homem em sua fisionomia de general e desvelando a mediocridade humana. A comparação que o título fornecia era incompatível com a imagem do pequeno sujeito, que tinha preocupações tão comezinhas e medíocres e que fugiam da legalidade.

A tentativa de restaurar o Tupi como a língua genuína do brasileiro marca o auge da zombaria à figura da personagem quixotesca no romance, ganhando o apelido pejorativo de Ubirajara. Policarpo vira motivo de riso e de galhofa da cidade inteira, seu nome circula pelas páginas jornalísticas por uma semana por escrever ao Congresso pedindo a adoção da nova língua, para ele, a verdadeira língua brasileira. A atitude do herói, mais uma vez, ombreia a ordem estabelecida; a repetição grotesca do fato denuncia um estranho que ameaça à paz do local e provoca o escândalo social. Tais 
comportamentos quixotescos podem ser lidos pelo prisma da sátira menipeia assinalada por Bakhtin (2010):

São muito característicos na menipeia as cenas de escândalos, de comportamentos excêntricos, de discursos e declarações inoportunas, ou seja, as diversas violações da marcha universalmente aceita e comum dos acontecimentos, das normas comportamentais estabelecidas e da etiqueta, incluindo-se também as violações do discurso. (BAKHTIN, 2010, p. 139).

Dessa forma, a atitude do protagonista não condiz com a realidade social do país, provocando o estranhamento do povo, assim como, aponta-se como a tentativa de burlar a ordem imposta e aceita socialmente. A representação dos escândalos sociais é um aspecto legado especialmente para o romance; tais traços fogem às características da épica reafirmando a distância, por meio do riso, entre os dois gêneros. A configuração romanesca joga com todos os aspectos penosos da vida humana; de forma alegre, estiliza o fato e conduz à reflexão via comicidade.

Policarpo Quaresma, cidadão brasileiro, funcionário público, certo de que a língua portuguesa é emprestada ao Brasil... - Usando do direito que lhe confere a Constituição, vem pedir que o Congresso Nacional decrete o Tupi-Guarani como língua oficial e nacional do povo brasileiro. (BARRETO, 2008, p. 62).

É notória a atitude grotesca do herói romanesco; do mesmo modo, a interlocução com a obra de Cervantes é visível, principalmente pela elaboração discursiva. A seriedade das palavras torna-se risível apenas pelo grotesco do ato que não condiz mais com a atualidade do país enunciado. Percebe-se que o narrador ideólogo continua em busca da comprovação de sua ideia, demonstrando o desprezo da população brasileira pelas coisas nacionais em nome do estrangeirismo. A jocosa criação do funcionário público metódico que não muda seus atos por mais de vinte anos era a figura mais reta para composição de um sujeito alienado: Quaresma, assim como não mudava seus hábitos por longos anos, não mudará sua concepção de restauração da cultura brasileira de forma rápida. Em diálogo com a situação social brasileira, Policarpo é uma ironia da população carioca do limiar do novo século. Percebe-se que o Rio de Janeiro, ao reconhecer a precariedade que estava se alastrando no espaço e o distanciamento dos estrangeiros do local, procurou se afastar das coisas locais em nome dos hábitos estrangeiros - a cultura popular passa a ser desprezada.

A descrição da nova vida do Major no sítio é realizada comicamente, marcando tanto a percepção alienante do país, numa espécie de insulamento, que poderia viver 
apenas da subsistência de sua agricultura, quanto da narração risível das cenas da vida no campo:

O flange batia na erva, a enxada saltava e ouvia-se um pássaro ao alto soltar uma piada irônica: bem-te-vi! O major enfurecia-se, tentava outra vez, fatigava-se, suava, enchia-se de raiva e batia com toda força; e houve várias vezes que a enxada, batendo em falso, escapando ao chão, fê-lo perder o equilíbrio, cair, beijar a terra, mãe dos frutos e dos homens. (BARRETO, 2008, p. 96).

O rebaixamento do herói salta aos olhos do leitor no relato trágico, mas que, devido à forma que é descrita, se torna risível. A natureza vence Policarpo, e a trajetória do herói fracassado continua em sua tese: ao Brasil não interessavam mais os seus maiores bens referendados na língua, na agricultura e na cultura. Os livros que diziam tudo já não traduziam mais nada perante o quadro letárgico do país. Seguindo os passos da história, a corrupção alcançava os locais mais fugidios, sendo o homem da terra um grande sofredor das opressões do Estado. "O empregado de Policarpo Quaresma, Felizardo, dissera a Olga Coleoni, que era inútil trabalhar para melhorar a terra porque pessoas como ele não recebiam ajuda alguma do governo, o qual favorecia os imigrantes à sua custa" (OAKLEY, 2011, p. 125).

Ainda se nota que, diante de todas as demonstrações fracassadas de salvar o Brasil de seus problemas, o major é derrubado pelas circunstâncias sociais, pelo desapego ao conhecimento, flagrando claramente nas linhas do romance uma hostilidade ao saber e ao refletir. A tranquilidade procurada no sítio "Sossego" por Policarpo Quaresma foi quebrada pela presença das saúvas e da população corrupta que vivia próximo a sua nova estadia, assoberbada pelos impostos cobrados pelo governo. "Como era possível fazer prosperar a agricultura com tantas barreiras e impostos" (BARRETO, 2008, p. 151). Mais uma vez o Brasil mostrou para nosso herói que suas atitudes - enunciadas nas primeiras linhas romanescas - de honestidade não serviam àquele país e dele foi devorada a possibilidade de uma vida tranquila e da salvação de sua pátria, restando apenas o riso.

A contradição entre o discurso que marca o limiar da vida no sítio e a invasão das saúvas, as dificuldades para se trabalhar com a terra, assim como os problemas do cidadão que mora no campo, sem nenhuma ajuda de custo do governo, marca o desencontro de pensamento. O nome do local é o primeiro contraste, pois de "Sossego" não há nada; avistam-se a inquietude e a corrupção humana. Da mesma forma, as pessoas que inferiam nas palavras de Quaresma um grande sonho de Brasil, riam de tão grande ingenuidade, pois apenas os moradores do recinto reconhecem os reais problemas que o morador do 
campo enfrentava. A paródia de um Brasil desestruturado e arcaico torna o personagem objeto risível, uma vez que continua mergulhado em uma visão alienante do país, sem perceber as reais mudanças que passaram a configurar no seio social.

$\mathrm{Na}$ terceira parte do romance, consagra-se a união entre a alienação e a autoconsciência narrativa. Quaresma deixa o sítio e vai para a guerra salvar o Brasil. Com o fim da revolta, deixado por todos, Policarpo é condenado à morte por traição. A narrativa finda apoteoticamente com a morte do protagonista e com seu sonho de Brasil desmistificado. "Finalmente, chega à conclusão de que todo o empenho humano é, em última instância, totalmente inútil" (OAKLEY, 2011, p. 95). Ao necessitar da ajuda das pessoas que comandavam o país, até seu grande amigo e sua sobrinha que tanto o acompanharam ao longo de seus momentos de loucura o deixaram, pois viram que essa era a única maneira dele morrer como herói. Leiamos o trecho citado:

\footnotetext{
Com tal gente, era melhor tê-lo deixado morrer só e heroicamente num ilhéu qualquer, mas levando para o túmulo inteiramente intacto o seu orgulho, a sua doçura, a sua personalidade moral, sem a mácula de um empenho que diminuísse a injustiça de sua morte, que de algum modo fizesse crer aos seus algozes que eles tinham direito de matá-lo. (BARRETO, 2008, p. 154).
}

A pátria, tão amada, não o salvou da morte, não lhe rendeu nenhum tipo de benefício ou honraria, apenas acabou com sua vida. A figura da personagem fracassada se configura no fim do enredo. Em todos os objetivos pleiteados, Policarpo sofreu derrocadas, vencido, restando apenas o riso trágico perante a inadequação de suas ações ao período e ao patriotismo. O final da trama demonstra o reconhecimento do major de que tudo que realizou em nome de seu país não o fez mudar em nada e que a luta por uma sociedade mais justa e igualitária, pela reconstituição de uma cultura, era impossível. Fala-se que o herói romanesco é apenas mais uma metáfora do próprio escritor e sua grande tentativa de recuperar a vitalidade de seu país, mas também retratar o seu povo com seus vícios. “Triste fim de Policarpo Quaresma pode ser entendido como um discurso metafórico da construção imaginária do Brasil e da sua gente" (GERMANO, 2000, p. 20).

Nesse momento nos encaminhamos para a última obra publicada do escritor, Clara dos Anjos (1922), deixando para trás outros dois romances: Numa e a Ninfa (1915) e Vida e Morte de M. J. Gonzaga de Sá (1919). O enredo narrativo se abre encenando a vida dos habitantes do subúrbio carioca, marcada pela simplicidade dos gestos e das pessoas que compunham o espaço. Por meio de uma vaga ironia, o enredo romanesco vai sendo tecido, indo tanto às qualidades dos residentes do espaço quanto da estrutura do 
local, construindo um grande painel da periferia do Rio Janeiro. Tal artifício narrativo serve para compor o cenário onde o clímax da história vai se desenrolar. "Agora, porém, e mesmo há vários anos, estava em plena posse do seu 'buraco' como ele chamava a sua humilde casucha" (BARRETO, 2011, p. 17). O lirismo da narração, mesclado com a coloquialidade da linguagem cotidiana se direciona para Joaquim, cidadão que enfrentou diversas dificuldades na vida para conseguir ter seu lar e viver uma vida tranquila e pacata com sua família: a esposa e a filha Clara dos Anjos.

Nessa narrativa, não raro, o leitor é confrontado com o personagem fora de suas vestes oficiais. A narração da história de Joaquim, assim como a da maioria dos outros personagens da trama, apresenta-se dentro dos aspectos penosos da vida, das tristezas, dos sofrimentos e da luta constante pela sobrevivência. A figura do herói rebaixado permanece central nas composições romanescas do escritor, procurando na vida não oficial a integridade do homem mediante a exposição dos vários estados de alma do indivíduo. A apresentação das qualidades positivas do sujeito está mesclada com as negativas que produzem a ambivalência do caráter humano e, por conseguinte, da própria vida humana. $\mathrm{O}$ riso, enquanto legado humano, procura representar as fragilidades da vida e, através da comicidade, mostra que elas são inerentes à própria natureza do homem.

O realismo presente na descrição do espaço romanesco se depara com um componente imprescindível para a obra: o registro de uma seita religiosa que chegou ao subúrbio abre brecha para a composição de uma grande crítica às religiões. Sob a figura dos "bíblias", casa religiosa comandada por um estrangeiro - Mr. Quick Shays - a crença das pessoas é colocada em pauta. Com a nova religião, a narrativa enceta-se na católica, sob a figura dos padres, que vivem de roubar as pessoas; por outro lado, a nova crença estava contaminada por todos os vícios, sem dar muita opção à sociedade:

\footnotetext{
De quando em quando, um cidadão protestante dessa raça que deseja a felicidade de nós outros, na terra e no céu, à luz de uma sua interpretação de um ou mais versículos da Bíblia, funda uma novíssima seita, põe-se a propagalo e logo encontra dedicados adeptos, os quais não sabem muito bem porque foram para tal novíssima religiãozinha e qual a diferença que há entre esta e a de que vieram. (BARRETO, p. 19).
}

Perante a narração irônica da situação religiosa da periferia, o uso dos aumentativos e diminutivos reforçam a sátira concernente à população; assim como o nome da personagem em estrangeiro é uma espécie de sátira aos costumes brasileiros, voltados, em especial, para o culto ao exótico. Do mesmo modo, todas as religiões são 
iguais, todas querem roubar o povo, ficando como divino - exclusivamente - o capital. O contraditório entre os dois seguimentos religiosos é a ambivalência da própria vida das pessoas, pois vão a diversos tipos de cultos, não sabem a diferença entre nenhum deles, mas, no final de tudo, o filho não pode deixar de ser batizado na religião cristã:

Os frequentadores dessa ou daquela natureza lá iam sem nenhuma repugnância, pois é próprio do nosso pequeno povo fazer uma extravagante amálgama de religiões e crença de toda a sorte, e socorrer-se desta ou daquela conforme dos transes e momentâneas agruras de sua existência. Se se trata de afastar atrasos de vida, apela para a feitiçaria; se se trata de curar uma moléstia tenaz e renitente, procura o espírita; mas não falem à nossa gente humilde em deixar de batizar o filho pelo sacerdote católico, porque não há, dentre ela, quem não zangue: "Está doido" Meu filho ficar pagão! Deus me defenda! (BARRETO, p. 20).

A carnavalização das crenças é uma forma de riso das atitudes da população do período - em que a moral religiosa que impera é a católica, mas perante as necessidades da vida, todas as outras servem, constituindo a pluralidade discursiva da vida e revelando a comicidade.

Nos meandros de uma periferia arrolada por suas alegrias e tristezas, a narrativa entra na composição da história a que se propõe realmente a enfatizar: a relação entre Cassi Jones e Clara dos Anjos. O rapaz, ao qual a sátira persegue desde o nome, ou seja, Jones havia sido inventado apenas para dar ares de estrangeiro, possui a seguinte descrição: "Era Cassi um rapaz de pouco menos de trinta anos, branco, sardento, insignificante, de rosto e de corpo; e conquanto fosse conhecido como consumado 'modinhoso', além de o ser também por outras façanhas verdadeiramente ignóbeis, não tinha as melenas da virtuose do violão, nem outro qualquer traço do capadócio" (BARRETO, 2011, p. 25).

Cruzando as pegadas do malandro, vemos nessa narrativa a herança do Leonardinho, de Memórias de um Sargento de Milícias; a construção do anti-herói, que possui as facilidades na vida para construir um futuro exitoso, principalmente pela vida farta que a família oferta, sinaliza para o sujeito que se desvia dos elementos elevados da vida e percorre pela picardia do cotidiano baixo. A vida fácil, desenhada por meio da história de Cassi Jones, cantor de modinhas acostumado a frequentar casas respeitáveis, expõe o sujeito e desvenda a outra face, a do malandro: Cassi se torna reconhecido principalmente por enganar moças ingênuas, engravidá-las e sumir. "É um bandido acudiu Alípio. - Ele merecia mais do que cadeia; merecia ser queimado vivo. Tem 
desgraçado mais de dez moças e não sei quantas senhoras casadas" (BARRETO, 2011, p. 64).

O sujeito, ao qual sua imagem se torna um grande escândalo social, exposto inclusive nas páginas jornalísticas, transforma-se em um dos principais ícones de ridicularização do narrador, em que a praça pública impera enquanto meio de desvendamento da natureza oculta do homem. Por outro lado, sua origem - pais bem colocados socialmente - e uma boa aparência, demonstram para a inocência das jovens e, em algumas ocasiões, de seus pais pobres, um grande homem para o relacionamento. A crítica aos interesses se afigura nas diversas relações que as jovens, sob o signo da ilusão, se relacionam com o malandro, procurando melhorar de vida.

Por sua vez, Clara dos Anjos é descrita como uma personagem enigmática, que acreditando na esperteza que possuía, se deixa enganar pelo malandro. As contradições que marcam a protagonista estão indiciadas no nome próprio: "Clara" remete-se ao branco, mas nossa personagem é negra; anjo se liga à pureza, mas o final da narrativa caminha por outro viés, desfazendo a natureza angelical da moça. "O nome Clara dos Anjos e suas vocações permanecem no romance como o polo contraditório da denúncia. Nessa linha o nome é irônico, no sentido socrático do termo, ao levar o leitor a tomar consciência da contradição" (CURY, 1981, p. 39). Nesse momento, confrontamos o primeiro deslocamento de sentido, em que significante e significado não comungam, o real demonstra uma coisa, e o abstrato, outra, conduzindo para o riso. Shopenhauer (2005) falava que o desencontro entre o real e o abstrato seriam as principais formas de acesso ao riso, pois se torna estranho, diferente daquilo que o espectador espera. A ingenuidade da moça corrobora para o cômico, uma vez que se vê enganada pelo malandro mesmo sobre alerta da maioria da população do subúrbio. Além do mais, o nome da moça continua reafirmando as contradições do subúrbio.

O traço deslizante da narrativa aponta a ambivalência na própria vida. Um dos personagens considerados mais éticos da obra, Marramaque, no final do enredo, morre. $\mathrm{O}$ velho, com ares de poeta e transitador entre as diversas camadas sociais, era considerado o sujeito ideal para falar de Cassi Jones; suas investidas contra o malandro são as investidas de um sujeito, quase que solitário, pela ordem de um local. Entretanto, a vida deslocada, sem nenhum tipo de ordem que a sociedade vem sendo representada, não abre espaço para as atitudes moralizantes do homem. Cassi Jones manda matar a única pessoa que poderia atrapalhar seus planos de desgraçar mais uma moça. O final da 
narrativa demonstra a autoconsciência da protagonista em sua condição de negra e pobre, estatuto que não agradava os "bons partidos" de uma sociedade arcaica, branca e patrimonial.

A narração de uma pilhéria quase no final da narrativa aparenta-se a um conto popular da literatura oral. A descrição de um enterro, no qual os carregadores do caixão transportaram, por um longo percurso, o corpo do defunto é um grande caso do gênero sério-cômico. O lirismo na narração tragicômica da vida, das lágrimas derramadas durante o trajeto é alimentada pelo álcool, demostrando o heroísmo das classes populares:

Houve, porém, uma ocasião, que o corpo não chegou a seu destino. Beberam tanto, que o esqueceram no caminho. Cada qual que saía da venda, olhava o caixão e dizia: Eles que estão lá dentro, que o carreguem. Chegaram ao cemitério e deram por falta do defunto. 'Mas não era você que o vinha carregando?'- perguntava um. 'Era você' - era você - respondia o outro; e, assim, cada um empurrava a culpa para o outro. (BARRETO, p. 80).

A perda do caixão é a comicidade da cena. Barreto flagrou com muita vivacidade esse momento da vida da população do subúrbio, constituindo uma das partes mais importantes dessa obra, imiscuída com a tragédia final que marca a vida da jovem, atravessada pelo preconceito da família de Cassi, apontava simplesmente um quadro recorrente na vida das famílias pobres do país. Do mesmo modo, a descrição da periferia com seus contrastes sociais, denota a vida carnavalizada, fora dos elementos elevados, demonstrando que, mesmo perante as dificuldades, o homem continuava sua vida, com suas facetas que a história silencia.

Esses vários narradores que traçaram essas histórias romanescas nos ensinaram a rir e a chorar, mas resolveram que, no final de tudo, o riso é sempre a escolha mais certa, pois não adianta chorar, - como bem exemplifica o final de Triste Fim de Policarpo Quaresma, Sofia e Ricardo Coração dos outros -, porque a vida é uma eterna representação, um grande coro de vozes e máscaras que circulam em cada época e criam e recriam seus costumes. Grotesco ou não, eles materializam uma época inacabada, de um sorriso congelado sob fissuras de dor e de lágrimas, mas que sempre termina em uma sonora gargalhada. 


\section{O riso nas crônicas e nos contos de Lima Barreto}

No desvio de algum rincão do universo inundado pelo fogo de inumeráveis sistemas solares, houve uma vez um planeta no qual os animais inteligentes inventaram o conhecimento. Este foi o minuto mais soberbo e mais mentiroso da história universal, mas foi apenas um minuto. Depois de alguns suspiros da natureza, o planeta congelou-se e os animais inteligentes tiveram de morrer.

(NIETZSCHE, 2001, p. 07) 


\subsection{Paródia e carnavalização em Os Bruzundangas}

No primeiro capítulo, fazemos referência a um dos principais conteúdos das narrativas romanescas, a sátira menipeia, como uma das influências centrais das narrativas oriundas de terras europeias, das quais se tornou a grande influência das narrativas mundiais. Atentando-se para os ensinamentos de Mikhail Bakhtin (2010), que ressalta a grande afluência de uma cosmovisão de mundo como característica norteadora das menipeias, acentuamos que esse gênero carnavalizado é apontado pelo teórico russo como detentor de uma particularidade singularizada: "trata-se de uma espécie de gênero 'jornalístico' da Antiguidade, que enfoca em tom mordaz a atualidade ideológica." (p.135). A visada do pensador direciona-se para o caráter de confronto que estava presente nas narrativas romanescas desde a antiguidade; do mesmo modo, a presença do discurso jornalístico parece integrar essas obras há muitos anos, principalmente pela visão de mundo que procuravam apresentar ao leitor. Ainda nas palavras do pensador essas narrativas:

\footnotetext{
São impregnadas de polêmica aberta e velada com diversas escolas ideológicas, filosóficas, religiosas e científicas, com tendências e correntes da atualidade, são plenas de imagens e figuras atuais ou recém-desaparecidas, dos senhores "das ideias" em todos os campos da vida social e ideológica (citados nominalmente ou codificados), são plenas de alusões a grandes e pequenos acontecimentos da época, perscrutam as novas tendências da evolução do cotidiano, mostram os tipos sociais em surgimento em todas as camadas da sociedade, etc. (BAKHTIN, 2010, p. 135).
}

Perante as considerações de Bakhtin, somos capazes de perceber que as características ressaltadas entram em diálogo com os elementos que compõem a crônica brasileira. A mesma, tendo seu limiar no século XIX, foi instituída principalmente sob a pena de José de Alencar, Manuel Antônio de Almeida e Machado de Assis. Herdeira dos folhetins veiculados nos jornais, surge inicialmente como o retrato dos fatos domésticos da vida de um povo, entretanto, ao passar para o suporte livro, ganha contornos ficcionais e poéticos, aproximando-se largamente do conto - mediante a alegoria e a extensão do narrado. O hibridismo é visto como uma grande fonte da crônica contemporânea, alimentando-se de vários componentes estéticos para reforçar a informação que procura apresentar. Em termos de conteúdo, a crônica pode ser vista como a transfiguração de um dado real em um evento ficcional: não importa o assunto, mas interessa a apropriação discursiva do dado do cotidiano para uma nova esfera composicional, resultando, nesse 
sentido, em um novo texto, em um novo discurso sobre o tempo, marcado pela criticidade gerada pela hibridização. Para Débora Betânia de Santana (2006):

\begin{abstract}
A crônica, dentre os gêneros literários, é o mais leve, o mais suave e, talvez por isso, de leitura fácil e fluente. Com marcas jornalísticas, sempre apoiada nos fatos, de produção apressada, sujeita às restrições de espaço, em virtude da diagramação, revela-se um texto oscilante entre os limites e as liberdades próprias do jornal. Essa característica prende a crônica ao meio jornalístico, configurando-se como uma produção datada, sem compromisso maior com o futuro. (p. 29).
\end{abstract}

A proximidade com a realidade imediata pode ser vista como a forma que dá leveza à prosaística cronista. Além do mais, falar do cotidiano de um povo é falar com o povo, é trazê-lo para dialogar com a descrição que está sendo revelada. A linguagem, em uma mistura de ironia e sátira, desvela os assuntos com um humor sombrio, de rebaixamento, que entrelaça no gênero o sério e o cômico: ao mesmo tempo que estamos retratando assuntos sérios, somos convidados a refletir sobre os problemas denunciados. Candido (1979) corrobora com tal perspectiva ressaltando que:

Por meio dos assuntos, da composição aparentemente solta, do ar de coisa sem necessidade que costuma assumir, ela se ajusta à sensibilidade de todo o dia. Principalmente porque elabora uma linguagem que fala de perto ao nosso modo de ser mais natural. Na sua despretensão, humaniza; e esta humanização lhe permite, como compensação sorrateira, recuperar com a outra mão, uma certa profundidade de significado e um certo acabamento de forma, que de repente podem fazer dela uma inesperada embora discreta candidata à perfeição. (p. 13-14).

O tom humorístico - junto com a fragmentação do real - é visto como o elemento coercitivo da crônica. "Ela é amiga da verdade e da poesia nas suas formas mais diretas e também nas suas formas mais fantásticas, - sobretudo porque quase sempre utiliza o humor" (CANDIDO, 1979, p. 14). A comicidade se alastra como forma de revelação da verdade, de correção dos vícios sociais. A sátira, principal meio de difusão do gênero, desvela a realidade em formação de forma grotesca, agredindo seu adversário por meio do rebaixamento e da exposição de suas particularidades. Para Telarolli (1999):

O engenho na sátira estará sempre associado à redução, forma de degradação e desvalorização do satirizado pelo rebaixamento de sua posição e dignidade; esse efeito pode ser alcançado no campo do argumento, mas se estende também ao terreno do estilo e da linguagem. (p. 67).

A utilização satírica em sua composição procura comprovar uma ideia, uma verdade sobre o fato narrado. Bakhtin (2010) ressalta que: 
A particularidade mais importante do gênero da menipeia consiste em que a fantasia mais audaciosa e descomedida e a aventura são interiormente motivadas, justificadas e focalizadas aqui pelo fim puramente filosóficoideológico, qual seja, o de criar situações extraordinárias para provocar a experimentação de uma ideia filosófica. (p. 130).

Além do mais, a caricatura presente nessas produções, em sintonia com o aumento das proporções do narrado, procura dar veracidade ao escrito, provocando o riso e chamando a atenção para as descrições que percorrem a prosaística. $\mathrm{O}$ universalismo filosófico ainda se funde às características explanadas. A ideia do cronista é uma verdade sobre o mundo, a disseminação de sua ideia carrega-se, em alguns casos, de filosofias que que intentam, conjuntamente com recursos do humor, refletir sobre o assunto exposto, para assim, chegar à conclusão do fato.

Os Bruzundangas (1923), obra publicada somente após a morte do escritor, em 1923, é a união de várias crônicas escritas em momentos diferentes, mas por seu aspecto temático - em que trata, em especial, de um único assunto: a sociedade - pode ser lida como uma grande narrativa sob os fatos que se arrolam no exótico espaço. Em seu corpus, é possível vislumbrar não apenas a presença da sátira, como vem acompanhado do nome, mas também é visível o hibridismo, utilizando-se da crônica, do conto e, até mesmo, do aspecto romanesco. Essa desfaçatez narrativa do prosador pode ser vista como uma crítica à sociedade literária de sua época, uma vez que era impossível retratar todas as contradições do país em um único gênero.

A sátira é apontada como o gênero predominante da escritura; desde o título da obra, é possível perceber os elementos de rebaixamento que irão nortear os acontecimentos narrados. Com significado que é direcionado para a desorganização, para as coisas inúteis, sem valor, o leitor é conduzido para uma nação carnavalizada, descrita pelo tom satírico e de deboche, reconhecendo na escritura um "mundo às avessas".

O Grande Dicionário da Língua Portuguesa dá a "brunzundanga" ou "burundanga" o significado de "palavreado confuso", cozinhado mal feito pouco limpo" e "trapalhada". No plural, a expressão significa "ninharias". No prefácio do volume 7 das Obras de Lima Barreto, os editores de Lima Barreto concluem, razoavelmente, que esta mítica República de Bruzundanga deve ser vista pelo leitor como um país das trapalhadas (terra de confusão, bagunça, desorganização). (OAKLEY, 2011, p. 118).

Perante a definição, percebe-se o ideário crítico do narrador desde o limiar da história, retratando grotescamente o país; dessa forma, como um repórter ativo, passa a 
relatar as principais características do local, sendo que a forma descritiva ocorre por meio do rebaixamento, menosprezando constantemente o local. Por sua vez, a comparação direta à sociedade carioca do início do século XX brasileiro põe o leitor em confronto com seu próprio país, postando-se apenas como uma alegoria dos problemas e da corrupção do povo brasileiro. "A maior parte do seu humor tem como objetivo as coisas do Brasil. O Brasil injusto, até mesmo ilógico, é retratado com ironia fina e sátira nervosa que provocam, não o riso espontâneo e alegre, mas um riso recheado de dores latentes" (GERMANO, 2000, p. 26).

A narrativa pode ser lida como uma grande paródia aos fatos que cercearam o início da República brasileira. Parece que as descrições estão voltadas para acontecimentos reais da vida social carioca; entretanto, esses acontecimentos são estilizados, e passam a ser representados comicamente, marcados pelo jogo do simbólico e da carnavalização dos fatos. A sátira que percorre as histórias, ao mesmo tempo que rebaixa, conduz ao riso, pelo jogo retórico da comicidade, levando acontecimentos sérios para a vida social do país, serem lidos comicamente, tirando o peso dos acontecimentos por meio da brincadeira e dos contrastes. "Afora um ou outro que não se veste pelo figurino da maioria, o que eles publicam são sonetos rimadinhos, penteadinhos, perfumadinhos, lambidinhos, cantando as espécies de joia e adereços que se encontram nas montras dos ourives" (BARRETO, 2010, p. 63).

A amplitude temática, tratando dos principais acontecimentos sociais, compõe o olhar do intelectual para os problemas que compunham o espaço e aponta o conhecimento estrutural do país. Lima Barreto, nessa escritura, fala de quase todos os temas que pode se averiguar em um meio social. De forma crítica, a sociedade do espetáculo foi criada ficticiamente, sinalizando para a carnavalização da vida enquanto escritural artística, parodiando os principais seguimentos sociais - política, literatura, teatro, jornalismo - e sinalizando o modo grotesco de vida de um povo bestializado com a proclamação da República, como assinala José Murilo de Carvalho (1987).

A representação teatral humana, segundo Dirlenvalder Loyolla (2014), convida o leitor a vagar por um mundo das aparências, onde a máscara impera como simbólico das relações sociais; do mesmo modo, a crônica aparece como o gênero profícuo para o desvendamento da nação carnavalizada, uma vez que possibilita ao cronista a possibilidade de expor suas ideias acerca de fatos reais que compõem a sociedade. A criação da Bruzundanga barretiana foi apenas um artifício literário de distanciamento 
construído pelo prosador para deixar sua crítica de Brasil, constituindo uma alegoria dos problemas que reconhecia em sua pátria. Afora isso, o pensamento sobre o risível de Jean Paul nos ajuda a pensar a obra: para o pensador o riso está sempre no sujeito e não no objeto. Dessa forma, percebemos na escritura em análise que sua fonte de riso vem do olhar do cronista sobre um problema social do país que, em sua amplitude, poucas pessoas reconheciam - vivia-se uma utopia social, marcada pela miserabilidade da praça pública e por um grupo de cidadãos bestializados pelo sistema de governo.

A narrativa principia com um prólogo assinado pelo próprio escritor Lima Barreto. A ideia do narrador ideólogo é apresentada ao leitor por meio da paródia ao livro Arte de Furtar $^{6}$ (2005). Na sátira portuguesa, que por seu título poderia fazer referência aos ensinamentos do roubo, contradiz as expectativas; e, em seu enredo, encontramos um outro lado: apresentam-se, na escritura, os vários tipos de roubo que existem e os tipos de ladrões. Essa premissa é o mote de toda a narrativa de Barreto, pois o autor apresenta em sua obra exatamente os tipos de "ladrões" e a forma por que eles sucateiam a população. "Por intermédio dos dela, dos dessa velha e ainda rica terra da Bruzundanga, livremo-nos dos nossos: é o escopo deste pequeno livro" (BARRETO, 2010, p. 12). Além do mais, na obra portuguesa, o autor levanta larga crítica à política lusitana, assim como Barreto fará em sua Bruzundanga. Com a parábola da arte de furtar - "como os maiores ladrões são os que têm por ofício livrar-nos de outros ladrões" (BARRETO, 2010, p. 12) -, são rebaixadas as personae da história. É sob essa ideia inicial, apresentada pelo escritor da obra que o conjunto de crônicas se desenrola, dialogando, de alguma forma, com as palavras registradas por Nicolau Sevcenko (2003) acerca das reverberações sociais que marcavam o limiar do século XX: "cada qual procura enganar a cada um com mais vantagens" (p. 31).

O tom satírico está presente desde o princípio da obra. Desde a ironia encontrada no segundo parágrafo, com a expressão "despretensiosas "Notas", percorrendo aos qualificativos diminutivos dos grandes homens da sociedade - percebe-se o tom de rebaixamento nas expressões "açambarcador de cebolas" e "reservas mentais", qualificativo de um importante médico; "rabona de sarja e ares familiares do Santo Ofício", para um rapaz que conheceu no país; "mandachuva", qualificativo que

\footnotetext{
${ }^{6}$ A autoria da obra foi muito discutida ao longo dos tempos. Em meados do século XX foi estabelecido que a escritura era do Padre Manuel da Costa, sendo escrita em 1744. Ainda assim, muitas edições trazem a autoria anônima.
} 
acompanhará toda a coletânea de crônicas, fazendo referência ao presidente da República - estende-se a projeção estético-crítica da escritura barretiana. O rebaixamento visível nas expressões assinaladas que compõem a primazia do conjunto de crônicas alia-se com o conteúdo satírico e caricatural da sociedade bruzundanguense, terra constantemente comparada ao Brasil por meio de suas desgraças. Vladimir Propp (1992) pontifica que o riso de zombaria é um dos fundamentos principais da sátira, debochando especialmente do caráter humano e de seus aspectos morais. Esses pontos de vista do pensador dialogam diretamente com a obra em análise, pois o uso do discurso de zombaria procura, de alguma forma, denunciar os problemas sociais de um povo. Por conseguinte, a carnavalização surge como meio de denúncia para que o homem reconheça os problemas sociais e busque possíveis mudanças.

Além do mais, é importante registrar o estilo ferino e irônico do narrador desde o início da obra: as constantes negações, o uso das expressões no sentido inverso, o diminutivo, a criação de termos estrangeiros que não integram a língua brasileira, assim como a insistência no uso de nomes exóticos indicam o riso e a ridicularização dos costumes, - "quase todos os nomes apresentam uma feição cômica para denunciar os defeitos morais de cada personagem na engrenagem hipócrita do próprio poder" (FREITAS, 2001, p. 87) -, e contribuem para o aspecto cômico e satírico da obra. Tudo isso denota uma grande liberdade discursiva das escrituras do cronista, possibilitadas pela carnavalização, que se reafirma como uma forma de desalienação humana e fuga ao medo dos dirigentes do poder. Essa escolha de estratégia narrativa destaca-se como uma das principais características da crônica e procura dar leveza a narrações de fatos que, por sua natureza séria, tornar-se-iam muito fortes para a leitura. $\mathrm{O}$ estilo sério-cômico parece percorrer todas as obras do romancista, pois assistimos, na prosa artística barretiana, ao constante uso do riso para retratar acontecimentos sérios que marcam o seio social. O apagamento das fronteiras discursivas, entrecruzando a linguagem oficial com a do cotidiano, assim como o tom das palavras empregadas, enunciam a sátira aos costumes, colocando Os Bruzundangas como uma grande paródia do Brasil.

O primeiro capítulo da narrativa intitula-se "Os Samoiedas" que, como frisa Freitas (2001), significa "aquele 'que come a si', canibal” (FREITAS, 2001, p. 71), levando ao riso. A descrição do local, situado no ártico, como assinala a pesquisadora, faz referência direta aos locais frios, significando também uma escritura poética voltada para as friezas das relações, direcionadas, em especial, para o interior do indivíduo. O 
conteúdo discursivo é uma reflexão sobre a literatura da terra da Bruzundanga, ato esse que o narrador da história, ironicamente, deixa para o leitor que se trata de algo que ele não tem propriedade para falar. Mas mesmo perante essa negativa, ele não se furtou ao prazer de deixar algumas linhas sobre o quadro grotesco que caracterizava o estilo literário daquele povo. Observemos a passagem abaixo:

\footnotetext{
Eu cheguei a entender perfeitamente a língua da Bruzundanga, isto é, a língua falada pela gente instruída e a escrita por muitos escritores que julguei excelentes; mas aquela em que escreviam os literatos importantes, solenes, respeitados, nunca consegui entender, porque redigem eles as suas obras, ou antes, os seus livros, em outra muito diferente da usual, outra essa que consideram como sendo a verdadeira, a lídima, justificando isso por ter feição antiga de dois séculos ou três. (BARRETO, 2010, p. 13)
}

O purismo linguístico é o assunto que abre a obra, colocado em um capítulo dito especial. A linguagem é uma das principais veias barretianas, pois seria o primeiro elemento de contato do escritor com o povo. A utilização simbólica da língua, com o rebuscamento que o literato imprimia em suas obras, afastava o leitor pouco letrado, uma vez que não compreendia o que estava sendo falado. Para Sevcenko (2003), "Lima insistia em que as preocupações gramaticais e estilísticas não deturpassem a naturalidade dos personagens, nem fantasiassem os cenários" (p. 196). O emprego da ironia, em uma narração leve, visa a menosprezar a linguagem dos literatos do período, lidos sobre os aspectos formais e o retorno aos clássicos. O escritor carioca, por sua vez, acreditava na simplicidade das palavras literárias, na escrita que pudesse alcançar os diversos seguimentos sociais, e se apontasse como um dos principais meios de comunicação humana. No livro Lima Barreto: uma autobiografia literária, Prado (2012) destaca que "para um desenhista único, para um caricaturista, enfim, para um desenhista comentador diário da vida, da política, dos autores do seu país, a mais alta expressão do seu valor deve ser encontrada nestas duas qualidades primordiais: simplicidade de expressão e clareza de execução" (p. 97-98). Exatamente os elementos que, na perspectiva do carioca, faltavam às obras de seus contemporâneos e denotavam a ineficácia social de suas obras, desvinculando diretamente do ideal de literatura do escritor, que via nas escritas literárias um meio de comunicação humana.

Um fato, entretanto, predominava na sociedade de Samoieda: os escritos simbólicos eram as formas poéticas que agradavam à população. Nas palavras do narrador da história da Bruzundanga, a população não compreendia o que estava sendo falado, mas era exatamente na falta de entendimento que se avistava a erudição. "Quanto mais 
incompreensível é ela, mais admirado é o escritor que a escreve, por todos que não lhe entenderam o escrito" (BARRETO, 2010, p. 13). Perante o relato cômico da situação alienante pela qual o povo passava, a obra de arte perdia sua função, pois como poderia deixar alguma informação se não era compreendida? Diante desses pequenos fatos que se arrolam ainda no limiar da escritura, o escritor apresenta o teor da série de escritos; a Bruzundanga era composta por uma elite oficial e um povo alienado que era maltratado pelos grandes, mas continuava aplaudindo aqueles: perante a obra do ficcionista, percebemos que só havia um detalhe que unia todos os povos: a ganância.

O conto popular, "Sua Excelência”, que se encontra narrado no primeiro capítulo - também denominado "O General e o Diabo ou O Padre e o Diabo" - tece a face escondida que une todos os homens de uma forma risível, até no título. A ânsia de um pequeno homem de alcançar a posição de um grande governante é tão vultosa que ele sonha ser a figura; entretanto, mesmo no sonho sua vontade é aniquilada, uma vez que seu cocheiro o leva para local desconhecido e passa a ser visto não como o bom Manoel que o conduzia todos os dias, mas a figura do próprio diabo. Tal simbólica, além de denunciar ligeiramente a impossibilidade dos pequenos alcançarem poder, traz uma outra face: equaliza as visões, os desejos e as ganâncias sociais, unindo todo um povo. O literato Bruzundanguense é alegoricamente o pobre homem aniquilado pelo diabo, almejando alcançar o sucesso do grande artista grego que fez sua obra atravessar os séculos e se manter viva até nos nossos dias, sendo de fundamental importância.

A ideia tragicômica da vida é parodiada e pode ser resumida na expressão de Vladimir Propp: "Podem ser cômicos os raciocínios em que a pessoa aparenta pouco senso comum; um campo especial de escárnio é constituído pelo caráter do homem, pelo âmbito de sua vida moral, de suas aspirações, e de seus objetivos” (PROPP, 1992, p. 29). O escritor da pátria desorganizada é apenas o cocheiro do grande literato, sua obra não chega aos pés daquele, restando, perante o quadro fantástico enunciado, apenas o riso do narrador - a ganância humana ultrapassa os limites da própria vida, mas, ao mesmo tempo, a realidade o trai, recolocando-o em seu plano de vida real, e rindo da ilusão que percorre a vida daquele pobre homem.

A aparência social é uma das questões fundamentais debatidas no escrito barreteano. Ainda perscrutando a profissão de literato, o narrador, ironicamente relata que a despreocupação com o conhecimento era superada por uma grande atenção voltada para as vestes. Além do mais, essa profissão servia apenas para garantir a fama, não havendo 
um estudo sério, ou mais especificamente, uma atitude responsiva perante a sociedade, quebrando todo o ideal militante da obra. Dessa forma, a ridicularização da cena tem seu limiar com o uso caricato do nascimento literário da Bruzundanga por meio de um príncipe antigo da Samoieda, com nome Tuque-Tuque Fit-Fit, comedor de mamutes, fazendo referência direta ao título do capítulo e ao canibalismo. Ou seja:

\begin{abstract}
Os samoiedas, como vamos ver, contentam-se com as aparências literárias e a banal simulação de notoriedade, umas vezes por incapacidade de inteligência, em outras por instrução insuficiente e ou viciada, quase sempre, porém, por falta de verdadeiro talento poético, de sinceridade, e necessidade, portanto, de disfarçar os defeitos com pelotiquices e passes de mágica intelectuais. (BARRETO, 2010, p. 18).
\end{abstract}

O destronamento aos intelectuais do período mostra a falta de conhecimento desses profissionais; o olhar crítico satiriza as aparências e a forma "mágica" como esses profissionais mantinham esse estilo de vida. $\mathrm{O}$ desconhecimento aos estilos literários dominantes, sendo apontados enquanto norteadores do povo da Samoieda, apenas reafirma a denúncia e a comicidade literária. A referência à Grécia ao longo da narrativa, como nação utilizada, como exemplo para a população samoieda, vem para reforçar a antiguidade que se avistava nas concepções daquele país, aumentando, nesse sentido, o tom da sátira: "Sabe-se que os alvos principais de Lima Barreto são uma autoridade institucional que louva a linguagem arcaica, a erudição por si só e o esteticismo, todos eles obtidos a partir de modelos estrangeiros" (OAKLEY, 2011, p. 118-119).

As influências estrangeiras se tornaram essenciais para o povo bruzundanguense, sendo sempre bem acolhidas pelos poetas que passaram a imitar, e o compromisso da obra de arte ia sendo deixado de lado:

\footnotetext{
O ritmo, o estilo, a nobreza das palavras, a aristocracia dos assuntos e dos personagens, quando faziam romances, conto ou drama e a meditação dos versos que exigiam fosse feita como se se tratasse da base de uma triangulação geodésica. Ninguém, no entanto, podia sacar-lhes da cabeça uma concepção geral e larga de arte ou obter o motivo de eles conceberem separados da obra de arte esses acessórios, transformando-os em puros manipansos, fetiches, isolando-os, fazendo-os perder a sua função natural que supõe sempre a obra literária como fim. É ela, a sua concepção, a ideia anterior que a domina e o seu destino necessário, que unicamente regulam o emprego deles, graduam o seu uso, a sua necessidade, e o como que ela mesma os dita. (BARRETO, 2010, p. 23-24).
}

As ideias acima destiladas eram os principais fundamentos que caracterizavam a literatura da Bruzundanga, o que, por sua vez, era o pensamento de nosso escritor sobre seus contemporâneos, registrando claramente tanto um ideal militante que percorria seus escritos e o hiato que estabelecia com os demais literatos de seu tempo. As regras do 
espaço caminhavam por uma "falta de larga inteligência do mundo e do homem e facilitar-lhes uma crítica terra a terra de seminaristas mnemônicos" (BARRETO, 2010, 24). Em outras palavras, nessa pátria a literatura não possuía outro ideal senão a aparência social, o status perante a população fraca de conhecimento e espírito crítico, tornando-se incapaz de perceber as mazelas sociais que os rodeavam. O país era daquela forma porque a população o permitia e o fazia ser assim. O riso e o escárnio ficam para todo o povo, uma vez que a situação alienante integrava todo o seio social, delatando claramente o pensamento utópico do espaço.

O rebaixamento da visão do grande literato é uma das principais formas de equalização discursiva. A carnavalização mostra os homens em igualdade, destacando que eles não eram melhores que o resto da população. Esse modelo de fazer artístico reacende toda uma tradição crítica de literatura, procurando demonstrar os homens em pé de igualdade e limpar da cena os hábitos que elevam o sujeito acima do outro. Desse modo, a sátira aos costumes é a sátira tanto à alienação de um povo quanto ao endeusamento de outro, reafirmando a unificação discursiva: “ A sátira surge como essa forma de humor sagaz que usa o riso para tocar na ferida, escondida por uma panaceia hipócrita que a sociedade cria para disfarçar suas mazelas" (FREITAS, 2001, p. 61). O modelo de herói sob as vistas da população é rebaixado grandemente na crônica, e o deus que antes era lido, agora passa a ser visto como um malandro, um palhaço, um fantoche, vivendo sob a máscara do grande homem, restando, no final, apenas o vazio.

De forma geral, a cultura passou a ser retratada carnavalizadamente; se em questões literárias o país fracassava, no teatro não seria diferente. A repetição que o narrador registrou ao presenciar o mesmo espetáculo em diversos teatros demonstra a falta de criatividade dos teatrólogos, sob a luz de uma plateia que merecia o que estava sendo apresentado, uma vez que as representações eram sempre bem vistas. "As palmas choviam e, quase sempre, a cantora repetia a maravilha, tanto fazia rir a plateia" (BARRETO, 2010, p. 143). A música era desprezada, deixada de lado, como uma forma de apreciação das mulheres, procurando, de alguma forma, desprezar também a capacidade feminina. Os jornais, no entanto, não se furtaram ao escárnio, sendo apresentados sempre sob a lente da corrupção; sujeitos comprados, devendo seus trabalhos aos pagamentos e benefícios que poderiam receber. Sevcenko (2003) salienta que a insegurança que os jornais perpassavam no limiar do século XX os faziam frágeis aos mais variados subornos: "O principal dos quais era o suborno político, via de regra, 
praticado pelo próprio governo. O jornal passava assim a operar como um reforço do esquema de corrupção do regime" (p. 206).

A política, um dos principais alvos de Arte de Furtar, é desenhada na narrativa de Barreto grotescamente. A comicidade, que se apresenta desde as expressões linguísticas de rebaixamento, se unifica principalmente pelas características do conteúdo representado. Para o narrador da história da Bruzundanga, vivia-se em um local falido, no qual se descobriam riquezas de cinquenta em cinquenta anos, e passava-se, ao longo de todo esse tempo, sucateando esse bem. A presença de uma grande personalidade que pudesse trazer alguma solução para a República da Bruzundanga era sempre recebida com aplausos, como aconteceu com o Doutor Felixhimino Bem Karpatoso. Declarava-se acerca dessa personagem: "Se era advogado, médico, engenheiro ou mesmo dentista, não se sabia; mas todos tratavam-no de doutor" (BARRETO, 2010, p. 29). As medidas que o importante economista trazia para sua pátria eram grotescas de tão ingênuas que poderiam parecer, e os impostos, cada vez mais elevados, desgraçavam a população pobre. Mas, mesmo assim, a personagem era muito bem vista, trazendo de sua importante viagem de estudos à Europa “ botas, chapéus, bengalas, dernier bateau, como dizem os smarts das colônias francesas da Ásia, da África, da América e da Oceania” (BARRETO, 2010, p. 31). Na inteireza dos novos produtos adquiridos no estrangeiro, o doutor até passou a ser "tido como o parlamentar mais chique do Congresso Nacional" (BARRETO, 2010, p. 29).

Perante as descrições, é visível a zombaria do narrador à política do país. O retrato grotesco da cultura doutoral da república se contrastavam com a posição alienante da população que enxergava, nesses espetáculos públicos, os grandes feitos de um país. A presença do grande homem, frequentador de locais estrangeiros, ressurgia para o povo como um ídolo a ser idolatrado e aclamado, e os trabalhos, aos quais deveria prestar à pátria, são deixados de lado em nome da aparência e do título.

O Doutor Felixhimino era apenas um título, uma aparência para aquela sociedade. Sem o canudo, nada seria. Mas o título de doutor é que dava nobreza à sua alma humana. O cidadão que o possuía era dignamente honrado por todo o povo e até a constituição abria todas as portas para eles, até os impostos eram menores para essa classe de trabalhadores. A alusão dentro da obra caracteriza o sujeito apenas como uma máscara social, pois não interessava nada além do pergaminho. De certo modo, a crítica contundente aos títulos se configura pelo desprezo que o autor encontrava nesses homens, 
reconhecendo que não era por mérito que eram conseguidos, mas apenas pela posição importante que suas famílias mantinham. Ele mesmo se encontrou em posições muito difíceis, sendo reprovado por vários anos seguidos e deixando o estabelecimento de ensino sem a formação pretendida. Por outro lado, vivenciou a saída de vários colegas que pagavam aos professores para passarem nos exames finais; coisa impossível para sua pessoa perante a condição de pobreza pela qual sua família passava:

De forma que os filhos dos poderosos fazem os pais desdobrar bancas de exames, pôr em certas mesas pessoas suas, conseguindo aprovar os pequenos em aritmética sem que ao menos saibam somar frações, outros em francês sem que possam traduzir o mais fácil autor. (BARRETO, 2010, p. 59).

As contradições franqueadas entre o cidadão que possuía um título e aqueles que não o tinham se tornam as principais fontes da verve crítica barreteana: a população desprezava completamente as pessoas que não tinham formação superior e vangloriavam a capacidade daqueles que o possuíam - que em muitos casos eram comprados e não dignificavam o sujeito. "A manutenção da elite por meio da titulação promove um jogo em que o status de doutor dá direito à ascensão social e à política, que, por sua vez, servem como base para a aristocracia doutoral" (FREITAS, 2001, p. 88). Os problemas do ensino viram motivo da sátira do escritor por enxergar na elite um apreço ao distanciamento do cidadão pobre nos grandes meios sociais. A necessidade de apadrinhamento para alcançar cargos renomados na estrutura social reafirma a falta de ascensão social de um povo e a permanência de uma nobreza que deveria ter sido suprimida pelo capitalismo em ascensão.

Outrossim, na sociedade Bruzundanguense, dava-se valor apenas a três tipos de formação: médicos, advogados e engenheiros. A formação de uma nobreza coberta de títulos apontava as superstições de um povo que se rebaixava perante os títulos e convidava as moças casamenteiras a filar esses "heróis". A manutenção de privilégios vira motivo de denúncia narrativa justificada pelo aceite social, demonstrando um povo que, perante a admiração que possuía ao canudo, apenas reforçava a continuidade daquele hábito. Leiamos parte do texto:

Lá, o cidadão que se arma de um título em uma das escolas citadas obtém privilégios especiais, alguns constantes das leis e outros consignados nos costumes. O povo mesmo aceita esse estado de coisas e tem um respeito religioso pela sua nobreza de doutores. Uma pessoa da plebe nunca dirá que essa espécie de brâmane tem carta, diploma: dirá tem pergaminho. Entretanto, o tal pergaminho é de um medíocre papel de Holanda. (BARRETO, 2010, p. $59)$. 
A alusão ao título de médico coloca o leitor em um dos espaços mais risíveis das obras de Lima Barreto: as profissões. Dando especial atenção à figura do médico, o prosador constrói uma seara caricatural sobre a imagem do trabalhador da saúde, procurando, em todas as situações, diminuir seu conhecimento. "Uma das figuras preferidas pelos escritores satíricos do mundo inteiro é a figura do médico, sobretudo no teatro popular e nas primeiras comédias europeias" (PROPP, 1992, p. 82). Na maioria das narrativas do escritor, essa profissão aparece de forma rebaixada, assinalando para uma tradição literária risível, que desde o limiar destacava a figura soberba em seus aspectos risíveis: "O cômico reside na ignorância dos pacientes, na fé sem limites nos atos e nos procedimentos médicos, mesmo que não entendam seu sentido. A ignorância dos pacientes, aliada à superstição de doutor, garantia o seu sucesso entre os ricos e os pobres" (FREITAS, 2001, p. 90).

Por outro lado, os políticos não ficaram impunes à pena de Lima Barreto. Para o narrador barreteano: “Os seus políticos são o pessoal mais medíocre que há. Apegam-se a velharias, a coisas estranhas à terra que dirigem, para achar solução às dificuldades do governo" (BARRETO, 2010, p. 47). Tais pessoas, na Bruzundanga, não estavam preocupadas em resolver os problemas de sua pátria, na realidade, formavam apenas o coro de aparência, contribuindo largamente para a falência do país. O retrato grotesco que o narrador elabora indica a alienação de pensamento aos poderes pré-estabelecidos; por meio do jogo de destronamento, demonstra ao leitor um país falseado, preocupado, em especial, com o poder que passam a exercer com as demais pessoas.

Ao conseguir o cargo público, ignoravam a população, tornavam-se estrangeiros para aquela massa populacional que se avistava todos os dias: "Os seus políticos são a coisa mais medíocre que há. Apegam-se a velharias, a coisas estranhas à terra que dirigem, para achar solução as dificuldades do governo" (BARRETO, 2010, p. 47). As riquezas enunciadas à população estrangeira apenas atraíam cada vez mais um número exacerbado de imigrantes para o local, criando um grande acúmulo de pessoas sem condições de vida. As misérias humanas se alargavam, a falta de qualidade de vida caía, e aqueles grandes bens enunciados ninguém via, apenas se sabia a fama. Os compêndios geográficos faziam propagandas de um grande país, mas a realidade era outra: “O país, no dizer de todos, é rico, tem todos os minerais, todos os vegetais úteis, todas as condições de riqueza, mas vive na miséria" (BARRETO, 2010, p. 47). 
A eleição se torna um dos casos mais cômicos da escritura, sendo apontada pelo narrador apenas uma superstição: "Dentre as muitas superstições políticas do nosso tempo, uma das mais curiosas é sem dúvida a das eleições" (BARRETO, 2010, p. 95). O vazio que se encontrava por trás do nome dos candidatos jogados ao pleito caracterizava as eleições do país, justificando amplamente o grotesco que marcava o aparelho eleitoral. O deboche do narrador, o riso da situação instalada fica evidente desde o uso da expressão "superstição", denunciando, na realidade, que ela não existe, é apenas aparência, visando a mostrar algum tipo de legalidade para o povo, como no fragmento seguinte:

Na Bruzundanga, como no Brasil, todos os representantes do povo, desde o vereador até o presidente da República, eram eleitos por sufrágio universal, e, lá, como aqui, de há muito que os políticos práticos tinham conseguido quase totalmente eliminar do aparelho eleitoral este elemento perturbador - "o voto". (BARRETO, 2010, p. 59).

O trabalho que o serviço de contagem dava, assim como a certeza de que as pessoas votavam quase que exclusivamente em parentes, era o principal motivo que se eliminava os votos e escolhia os comandantes à revelia, lavrando as eleições e elegendo as pessoas de seu interesse. A ironia é evidente, tanto no uso da expressão "superstição", quanto na referência ao povo, enquanto um elemento perturbador das eleições. Ri-se de um modo de eleição que deveria governar para o povo, mas que os veem como constituintes perturbadores da nação. Delineando um quadro totalmente grotesco, o narrador põe os candidatos como ladrões, fá-los desfilar nas ruas, perturbar a liberdade do povo por meio de ameaças, o que impossibilita o deslocamento para votar. Aqueles que ainda se arriscavam votavam em quem os mesários determinavam, restando votos até aos mortos. $\mathrm{O}$ absurdo da narração enuncia a carnavalização e o conduz ao riso, marcado pela ironia na forma com a qual as eleições eram realizadas. O narrador da história resume o grotesco da situação com a seguinte assertiva: "Tais costumes eleitorais da Bruzundanga são fontes de muitos casos cômicos, mas, por serem quase semelhantes aos que se passam entre nós, abstenho-me de narrá-los” (BARRETO, 2010, p. 59).

Essa figuração das eleições faz uma retomada direta às eleições brasileiras, pois as fraudes que marcavam as eleições na República Velha continuavam mesmo com a ascensão da República, uma vez que os desejos dos grupos políticos mais fortes se mantinham perante as necessidades da população e o foto do cabresto continuava patente nos meios eleitoreiros. Desde as eleições que colocaram Floriano no poder, ultrapassando Prudente de Morais, até mesmo Campos Salles, considerado como o primeiro presidente civil, mantinha-se a relação de corrupção no pleito eleitoral. A narrativa de Barreto, desse 
modo, destaca-se como um grande quadro alegórico dos acontecimentos sociais que passaram a compor a primeira república brasileira.

O presidente, figura principal da política, ganha o apelido pejorativo de Mandachuva, sendo mencionada sua entrada no poder da seguinte forma: "a não ser que suba ao poder, por uma revolta mais ou menos disfarçada, um general mais ou menos decorativo, o mandachuva é sempre escolhido entre os membros da nobreza doutoral; e, dentre os doutores, a escolha recai sobre um advogado" (BARRETO, 2010, p. 59). O destronamento do presidente aciona toda uma tradição de literatura, heranças de grandes festas carnavalescas, como as saturnais, os festins - uma vez que nesses rituais residia a grande cosmovisão de mundo com a "ênfase das mudanças de transformações, da morte e da renovação" (BAKHTIN, 2010, p. 142). A caricatura do rei, aclamado pela população, transforma-se na imagem do bufão, personagem lendária que era rebaixada e se tornava motivo de riso do povo. Tais rebaixamentos levavam ao desvendamento social, demostrando um país marcado, em especial, pela desorganização, pela falta de estrutura e pela incapacidade de produzir decretos que caminhassem na direção das necessidades do povo bruzundanguense. Vejamos:

As leis são os esqueletos das sociedades, mas a feição de saúde ou doença
destas, as suas necessidades, terapêuticas ou cirúrgicas, são dadas pelo prévio
conhecimento e exame, no momento, do estado de certas partes externas e dos
seus órgãos vitais, que são o comércio, a sua indústria, as suas partes, os sonhos
do seu povo, os sofrimentos dele - toda essa parte mutável das comunhões
humanas, cambiantes e fugidias, que só os fortes observadores, com grande
inteligência, colhem em alguns instantes, sugerido os remédios eficazes e as
providências adequadas, para tal ou qual caso. (BARRETO, 2010, p. 71-72).

A figura presidencial é rebaixada largamente quando o narrador fala que a escolha é feita entre os habitantes mais néscios e medíocres e que sua origem é simplesmente um sujeito da roça, conhecedor de pequenas províncias, parcas leituras, e que não vivenciou a estada em grandes locais, apenas em cidades pequenas. A semelhança que se faz estabelecer com a ideia de pacato, a utilização da denominação de doutor da roça, assim como a frieza de suas atitudes levam-no a ser chamado de bonachão, apenas aumentando o tom da sátira, menosprezando, cada vez mais, a figura principal do país. Perante todos esses qualificativos de diminutivos, o narrador, ironicamente deixa para o leitor que a figura "menor" em muitos sentidos será o "Mandachuva" do país da Bruzundanga.

O rebaixamento, nessa obra, é a principal forma enunciativa utilizada pelo escritor, conduzindo ao riso por meio da frieza das expressões e da leveza linguística. Os adjetivos pejorativos denunciam uma escrita irônica, brincalhona, risível, mas um riso 
sério, ligado à denúncia social, ao retrato dos problemas da nação brasileira. Vale lembrar que a feição do riso, que passou a cercear a partir do século XIX, tinha objetivos prévios de denúncia e crítica social. Assim, as obras literárias, que passaram a ocupar suas páginas com esse estilo de representação, carregam em suas páginas uma grande denúncia social. As obras de Barreto, assim como as de Gregório de Matos, Manuel Antônio de Almeida e Machado de Assis, são formas narrativas de teor crítico muito assentado, reproduzindo, de certo modo, a cultura do povo e o pensamento filosófico do período.

A figura pública do bom homem do presidente se contrasta com a atitude teatral, com a máscara pública. Suas atitudes o levam a receber o apelido milagreiro de Messias. Reclusa-se em sua casa, passa a frequentar a igreja continuamente, dispensa muitos tipos de gastos, entre eles o literário; dessa forma, seu nome vai sendo traçado socialmente. As viagens, que tanto o aborrecem, e o clamor do povo são as partes desagradáveis do mandarinato; entretanto, fazem parte do espetáculo, da aparência, das necessidades para continuar a conseguir altos cargos públicos. Seus eleitores são uma sociedade alienada e comprada, são seus parentes, os padres que manipulam a mente das pessoas. A estrutura carnavalizada da sociedade vai se constituindo com os diversos seguimentos rebaixados e o título da obra gritando a cada descrição, reafirmando todo o ideário de desorganização social, de corrupção humana e, principalmente, de eliminação da população pobre, jogadas para fora dos grandes centros urbanos, em situações de vida calamitosas: "Bossuet dizia que o verdadeiro fim da política era fazer os povos felizes; o verdadeiro fim dos políticos de Bruzundanga é fazer os povos infelizes" (BARRETO, 2010, p. 48).

Os heróis de Bruzundanga são os verdadeiros anti-heróis, são as pessoas que nada fazem em prol do seu país. Se é cara ao leitor a comparação entre essa sociedade desorganizada socialmente e o Brasil, parece que uma descrição desfaz a Bruzundanga e faz nascer o Rio de Janeiro com a narração da Reforma Pereira Passos ${ }^{7}$ : "ele não quis assim e eis a Bruzundanga, tomando dinheiro emprestado, para pôr as velhas casas de sua capital abaixo. De uma hora para outra, a antiga cidade desapareceu e outra surgiu como se fosse obtida por uma mutação de teatro" (BARRETO, 2010, p. 88). A descrição do espetáculo público é o desenho de um grande feitio da capital do país daquela época, mas que representou uma grande tragédia para as famílias do local, jogadas para os subúrbios

\footnotetext{
${ }^{7}$ Construção de uma grande avenida no centro do Rio de Janeiro, demolindo mais de cinco mil residências; o resultado foi a alocação de milhares de pessoas para os subúrbios e favelas nos morros, sem condições higiênicas de saúde.
} 
sem nenhuma condição de obter qualidade de vida. Se o início da narrativa fala de se livrar dos pobrs, esse fato é um dos que mais comprova a forma com a qual os poderosos se livravam daqueles que, de alguma forma, poderiam atrapalhar a visão que o país queria demonstrar às comunidades estrangeiras.

Em linhas gerais, não há uma sociedade propriamente dita na Bruzundanga, não existe a manutenção dos costumes, o povo vive da sede do enriquecimento, do acúmulo do dinheiro, em outras palavras, da ganância social. Não se fala apenas de um local falido economicamente, mas também de ideias, de conhecimento, de vida, em que a incapacidade e a "pobreza mental" são os principais adjetivos que denominam aquele estilo de viver. Se o autor ideólogo abriu seu prólogo, querendo falar do ato de furtar e da constante tentativa dos grandes homens da sociedade em se livrar dos povos menores, pode-se dizer que, em certa medida, ele trouxe para seu leitor informações suficientes para comprovar seu discurso. Rebaixou e apresentou um país carnavalizado, mesclado pela sátira direta aos habitantes do local e pela proximidade com os acontecimentos das ruas. São evidentes os contrastes sociais: se, por um lado, um grupo de cidadãos desfilam suas riquezas, à margem de todo aquele espetáculo público, por outro lado, um grande número de indivíduos vive e revive suas misérias, mostrando claramente a antítese entre o "luxo e a miséria". Do mesmo modo, Lima Barreto faz desfilar na mesma praça o alto e o baixo, o rico e o pobre; essas aproximações narrativas são as que alavancam a sátira e equalizam os discursos.

Perante todos os relatos de rebaixamento enunciado ao longo da obra, o riso se manifesta tanto pelo conteúdo abordado, quanto pelas expressões linguísticas utilizadas. A escolha das imagens, que vão tecendo o enredo narrativo, aponta o cidadão sempre de forma rebaixada, menosprezando os acontecimentos sociais e ridicularizando a forma de vida da população. As caricaturas utilizadas ao longo da obra derivam "da real convicção de que a realidade não fala por si; é preciso que ela seja exagerada criticamente para revelar os seus defeitos e expor as deformações que despertem o desprezo geral" (SEVCENKO, 2003, p. 197-198). Os recursos estilísticos enunciam a desconstrução de um mundo sério, transformando, por meio das imagens estilísticas empregadas, em um mundo alegre, carnavalizado, em que os discursos empregados se equalizam, unificam, deflagrando a familiarização do sujeito com o mundo.

O objetivo do escritor era encenar, de forma diversa, a história do povo brasileiro e distanciar de uma tradição de literatura que enxergava na forma a qualidade essencial 
da escritura: falar de um povo de forma rebaixada é denunciar as mazelas sociais que estavam cravadas naquele povo. Além do mais, a apropriação paródica de outros textos que compunham uma tradição de literatura de crítica social por via da sátira compõe o projeto estético do riso barreteano. O riso era a forma de levar o leitor a tomar conhecimento dos problemas sociais, assim como a carnavalização, e de estar consciente da necessidade de mudança e/ou de renovação das atitudes sociais do país.

\subsection{A representação do riso nos contos de Lima Barreto}

O tempo brinca e ri.

(BAKHTIN, 2013, p. 71)

O estudo das teorias do conto é também um voltar a nossas próprias raízes culturais relacionadas à literatura oral e à transmissão das histórias ao longo dos tempos. O narrador de histórias orais apresentava um estilo peculiar de chamar a atenção de seu espectador para a trama que estava sendo contada. Tais recursos da arte de contar foram transmitidos ao conto quando esse ganhou forma literária.

Há todo um repertório no modo de contar e nos detalhes do modo como se conta- entonação de voz, gestos, olhares, ou mesmo algumas palavras e sugestões - , que é passível de ser elaborado pelo contador, neste trabalho de conquistar e manter a atenção do seu auditório (GOTLIB, 2006, p. 13).

Nas palavras de Cortázar (2006), o que determina o conto é o limite de páginas, a concisão que o autor emprega naquelas rápidas linhas e leva seu leitor, em um único fôlego, a passar por toda a história narrada. O clímax, que deve estar presente desde o começo da narrativa, surge a partir da escolha correta do tema e da precisão com a qual se desdobra o suspense e provoca a tensão no espectador.

O tom do riso nas narrativas contísticas aproxima-se bastante da ironia, diferente da sátira que vinha sendo desenhada nas escrituras da crônica. Lima Barreto conseguiu, de alguma forma, construir uma variedade de humor. Desde os primeiros romances, é possível entrever em suas narrativas diversas possibilidades de riso, principalmente pela ação fantástica que marca algumas dessas tramas; e que em outras, fica especificamente o retrato direto do cotidiano de uma gente. A linguagem também é diferente, e aquelas palavras ferinas que rebaixam e expõem o indivíduo, muito das vezes, escapam nos contos em nome da brincadeira, da ironia que percorre as anedotas. Cury (1981) aponta uma 
diferença crucial entre a forma de narrar cronista e a contista, que, de alguma forma, corrobora para o tipo de riso presente em ambos os gêneros, pois para a autora existe:

O discurso dito consciente, que se lê sobretudo nas crônicas - discurso acentuadamente pela ordem cultural, e o discurso propriamente literário, em que o simbólico e o imaginário disputam o espaço do real num produto paradoxalmente chamado de ficção (p. 14).

Esses dois planos que a autora destaca se desdobram em modos de narrar diversos; dessa forma, o conto, por sua natureza totalmente ficcional, dá mais espaço para a ironia. Por outro, a crônica, por utilizar fatos do tempo histórico, se aproxima mais da sátira.

"A nova Califórnia", primeiro conto do autor é tido como um ensaio preliminar do grande romance Triste Fim de Policarpo Quaresma. Tal denominação deveu-se, em especial, pela forma alienante da sociedade à voz do estado e ao desapego às funções das letras. Mas o leitor é capaz de perceber que as narrativas se distanciaram, e a figura de Flamel não é a figura de Policarpo. "O Major Quaresma, evidentemente autodidata, está sob o domínio do saber que adquiriu por meio do estudo e, de certo, esquecido dos limites desse saber. Raimundo Flamel, protagonista de "A nova Califórnia", domina seu saber ao mesmo tempo que se mostra extremamente consciente das limitações dele" (OAKLEY, 2011, p. 97). O herói contista foi um assíduo manipulador, e sua esperteza apenas acabou com a pequena cidade. O fantástico e, ao mesmo tempo, ilusório quadro tecido na narrativa perfila para o leitor o grotesco da situação narrada, constituindo, especificamente, uma alegoria principalmente à ganância humana e à crença no discurso do outro que manifestava algum tipo de conhecimento. Marcado pelo suspense desde o princípio, o conto provoca a curiosidade desde os primeiros relatos da chegada do novo habitante à pacata cidade, permanecendo na mesma tensão até as linhas finais.

Fruto do mito da Alquimia Medieval e também rascunhando um fato real, a corrida do outro americano, a contística joga com os dogmas humanos e a ganância social. Dessa forma, a narrativa é composta de três partes: na primeira, conhecemos o protagonista da trama, o desapego da população, a repentina fama e a figura do capitão Pelino. Na segunda, o químico arranja três pessoas importantes para serem testemunhas da experiência e que lhe darão crédito, sob o pretexto de que não gostaria que o mundo da ciência tenha conhecimentos sobre sua experiência. Na última parte, o povo toma conhecimento do roubo dos mortos, pega os ladrões, descobre o motivo, e eles se matam para conseguir os ossos restantes no cemitério. 
"A Nova Califórnia" (1910) relata a história de Tubiacanga, cidade tranquila e não acostumada a ocorrer fatos marcantes, que viessem a interferir na vida da população. Mas a chegada de um estrangeiro tirou a paz do local, pois seu distanciamento do resto das pessoas e até um forno estranho que realizou em sua residência provocou a curiosidade nos residentes do lugar que, por alguns momentos, até o consideraram um bruxo: "E, pelos dias seguintes, Fabrício pôde contar que vira balões, facas sem corte, copos como os da farmácia - um rol de coisas esquisitas a se mostrarem pelas mesas e prateleiras como utensílios de uma bateria de cozinha em que o próprio diabo cozinhasse" (BARRETO, 2010, p. 63). Como é possível perceber claramente na descrição, os objetos descritos eram comuns, e poderiam constar em qualquer cozinha; manifestando apenas o quadro ilusório que começava a percorrer a cidade. A referência ao diabo torna a atitude da população risível; do mesmo modo, mostra uma construção narrativa cômica, que joga com os elementos do cotidiano e com os dogmas da população do espaço: "O alarme se fez na vila. Para uns, os mais adiantados, era um fabricante de moeda falsa; para outros, os crentes e simples, um tipo que tinha parte com o tinhoso" (BARRETO, 2010, p. 63). $\mathrm{O}$ aspecto religioso é um fator que contribui para a comicidade da narrativa por brincar com a moral do povo; semelhantemente, será crucial para o final da narrativa, uma vez que toda a religiosidade desaparecerá perante a riqueza.

A forma com a qual a narrativa vai sendo tecida, além do suspense que provoca no leitor, na arriscada tentativa de desvendar o futuro do estranho que acabou de chegar à cidade, também encaminha para o riso. A comicidade gira em torno da população perante as crenças religiosas e moralizantes. A alienação humana, como uma das ideias centrais do enredo, apresenta a população da cidade mergulhada em mundo utópico, sendo altamente manipulada pelas crenças, pelo conservadorismo e pela falta de pensamento autônomo: o que uma pessoa falava rapidamente atravessava a cidade, e todos viviam daquela ideia. A constatação de que o novo residente da cidade poderia ser um bruxo assusta a população, e a simbologia de um homem rezando o credo ao passar em frente à casa de Flamel reafirma os dogmas religiosos e sinaliza o aspecto risível do ato: "Chico da Tirana, o carreiro, quando passava em frente da casa do homem misterioso, ao lado do carro a chiar, e olhava a chaminé da sala de jantar a fumegar, não deixava de persignar e rezar um ‘credo' em voz baixa” (BARRETO, 2010, p. 64).

A imagem do coronelismo, do sujeito que comanda a cidade, se exaure na figura de Bastos, boticário da cidade: homem respeitado por todos, bastou pronunciar umas duas 
palavras, dizer que Flamel era um grande químico, para a cidade silenciar-se. "Tomando em consideração as informações de Fabrício, o boticário Bastos concluíra que o desconhecido devia ser um sábio, um grande químico, refugiado ali para mais sossegadamente levar avante os seus trabalhos científicos" (BARRETO, 2010, p. 64). A imagem do homem passivo e alienado vai sendo tecida ironicamente: a mudança repentina se torna símbolo da ingenuidade da população, tornando-se risível na medida em que não tem opiniões prontas. Essa mudança repentina de posição das personagens demonstra a ambivalência de pensamento, manifestando-se ao longo de toda a narrativa.

De diabo, o homem vira Deus. A contradição do pensamento anterior para o novo olhar da população - "tinha parte com o tinhoso" para "a tranquilidade do Messias" carnavaliza a sociedade; com seus conflitos, ela se assemelha a um jovem em busca do próprio eu. Do mesmo modo, a figura do herói começa a ser levantada na narrativa, que, diferente dos que percorreram as páginas romanescas, é aclamado por toda a população. Por sua vez, será possível, no final da narrativa, essa imagem entrar em conflito no imaginário do leitor, uma vez que a bravura desse leva à morte de todos. O lirismo que percorre a descrição da bondade do homem contrasta com o nebuloso destino das crianças, criando um ambiente bucólico e sombrio. Do mesmo modo, o homem considerado com a "bondade do messias" cria uma antítese quando comparado com a criação de ossos. A carnavalização da sociedade começa a ser construída, unindo discursos oficiais, marcados pela seriedade, com a linguagem de rebaixamento. A união dos polos opostos é o primeiro sinal que aponta a comicidade. A presença da vida séria, fora dos elementos do carnaval, conduz o homem alienado a um sistema de poder, sem visões e opiniões próprias.

O herói contista passou a deter grande popularidade no pequeno local, sendo objeto de exaltação da população. Suas palavras tranquilas chegaram a concedê-lo o título até de "pai da pobreza". Além do mais, a atitude solitária chamava a atenção de todas as pessoas, pois viam nessas atitudes do sujeito grandes ares de conhecimento. No plano narrativo, a construção da personagem produz na obra um grande suspense; a escolha dos quadros alegóricos - como o local para a realização da experiência - evidencia, de certo modo, os conhecimentos do herói e justifica a escolha do povo certo para fazer sua experiência, devido à ingenuidade, mas também à ambição - para conseguir seus objetivos, o protagonista precisava desses dois ingredientes: uma população alienada, procurando ídolos para se apoiar, e a ganância social. 
O apego aos títulos, mais uma vez, é confrontado por Barreto. A situação alienante do povo representava a utopia social. Até o Boticário, homem mais importante da cidade, se rebaixa perante a figura do importante químico, com seus artigos publicados e as revistas estrangeiras que chegam a sua residência. A ironia da natureza humana se restabelece, uma vez que estamos sempre subordinados a alguém superior, reforçando a atitude militante do escritor em todas as obras. Flamel aparece na narrativa apenas como uma alegoria para o narrador provar sua tese, em que a população pulula em dois blocos contraditórios: o do sujeito alienado e ingênuo e o do homem ganancioso.

A figura do gramático Pelino, que, diferente dos outros integrantes da trama, questionava a ação do novo herói, é vista com críticas e indiferenças pela população. A personagem, para Oakley (2011), representava a ordem do parco local: as pessoas da cidade o tinham enquanto o grande sábio, escritor de jornais. A chegada do novo habitante ameaça a ordem reinante. Desse modo, Pelino aparenta-se apenas como alegoria de um sistema que procura se manter e que luta contra a nova ordem, como bem constata Prado:

Pelino é a autoridade, "sábio" respeitado porque sabe gramática e é capaz, nesse "apostolado de vernaculismo", de corrigir e emendar as maiores glórias nacionais; Flamel, um sábio estranho para Tubiacanga: de origem ignorada e curioso comportamento, é homem de ciência que se atualiza e pesquisa. Ao reagir contra a presença de Flamel, Pelino se converte na ordem ameaçada, superada, depois, pela união Flamel-Bastos na consecução do projeto que buscava a fórmula de fazer ouro à custa dos ossos dos mortos do cemitério. (PRADO, 1976, p. 36).

A caricatura do gramático pedante é desenhada: Pelino vive a corrigir todos os habitantes da cidade em termos de língua; por seu turno, a figura do gramático era apenas uma metáfora da literatura parnasiana, voltada, em especial, para o jogo da sintaxe tradicional. A queda ao modelo imposto, a descrença da população em nome de um novo ídolo, era também a queda dos modelos puristas impostos socialmente e gritando por uma nova forma estilística. Entretanto, como afirma Oakley (2011), o gramático, perante a descoberta do saque aos ossos humanos, e sabendo da influência do químico, vê-se vingado de toda a população que não ouviu suas palavras; entretanto, a contradição logo se evidencia, pois, com a descoberta do ouro, a personagem é flagrada na atitude grotesca de escavação de ossos, brigando por um fêmur. Nesse sentido, toda a moral que havia pregado é descortinada, fazendo com que sua figura se equalize ao de toda a população que havia criticado, levando apenas ao riso, não do gramático em específico, mas da natureza humana como um todo. 
$\mathrm{Na}$ segunda parte da narrativa, o curso da história se modifica. Flamel pede para três importantes homens da cidade participarem de uma experiência: construir ouro com ossos humanos. Mesmo que a cena choque, a ganância era maior do que qualquer coisa, e os comandantes da cidade aceitaram participar da trama. O elemento fantástico começava a se sobrepor à realidade, mesclando com o imaginário, apontando claramente o grotesco da situação que passa a ser articulada. $O$ riso se manifesta como uma das principais fontes de denúncia social, de rebaixamento do pensamento de uma sociedade que só tinha olhares para a riqueza e vantagens que poderiam suceder das relações sociais: "Domingo, conforme prometeram, as três pessoas respeitáveis de Tubiacanga foram à casa de Flamel, e, dias depois, misteriosamente, ele desaparecia sem deixar vestígios ou explicação para seu desaparecimento" (BARRETO, 2010, p. 67). Os grandes cidadãos, pessoas de confiança de toda aquela pequena gente, os responsáveis por tudo que ocorria no local, foram manipulados pela sede da riqueza, pela vontade de ter, e aquele retirante que havia se infiltrado no espaço caladamente desapareceu, deixando apenas a miséria para o local.

$\mathrm{Na}$ terceira parte da narrativa, assiste-se a uma sociedade atormentada saqueavam-se os ossos humanos do cemitério. O desespero foi total, pensou-se na falta de respeito com os mortos. Como alguém poderia tirar o sossego daqueles que os deixaram e estão procurando o descanso eterno? "Era coisa pior, sacrílega aos olhos de todas as religiões e consciências: violavam-se as sepulturas do 'Sossego', do seu cemitério, do seu campo-santo" (BARRETO, 2010, p. 68). O susto do povo é narrado ironicamente, porquanto a contradição entre violência e sossego conduz ao riso, assim como fatos ingênuos, como a presença da frágil Cora, preocupada, em especial, com o destino de seus ossos após a morte: "Aí Cora queria os seus ossos sossegados, quietos e comodamente descansados num caixão bem feito e num túmulo seguro, depois de ter sua carne encanto e prazer dos vermes" (BARRETO, 2010, p. 69). A descrição lírica da aflição dá leveza à narrativa que, em vez de assustar as pessoas perante o grotesco do acontecimento, apenas provoca o riso. A zombaria aparece como a forma de composição dos sentimentos do povo, visando a criticar o modo utópico de vida social e trazendo uma nova visão de mundo que norteará o final do enredo.

Montou-se uma vigília para pegar os ladrões: certo dia, viram os ladrões chegarem; pegaram-nos, bateram tanto que um morreu na hora, o outro fugiu, e um deles ainda ficou vivo para contar a história. Quando falou o porquê, toda a população quis 
saber a receita. A revolta que antes se avistava rapidamente foi superada em nome do dinheiro, não existia mais moral religiosa ou ética, a riqueza imperava. As contradições de pensamento levam à comicidade. A ingenuidade que marcava as primeiras linhas da narrativa é quebrada, e agora o narrador constrói um grande palco carnavalizado, onde fica apenas de longe olhando e rindo de todo aquele espetáculo humano que marcava a miserabilidade do homem. A ironia aos dogmas e à moral que passa a desconhecer a ética fica patente no final da narrativa, restando apenas o riso.

A carnavalização social se evidencia claramente na terceira parte do conto. A fuga ao discurso de poder é quebrada; a confiança que o povo mantinha nos importantes homens da sociedade é deixada de lado, equalizando os discursos e as visões sociais. Ademais, as barreiras hierárquicas e os discursos são também quebrados, as desigualdades são postas lado a lado, apontando novas relações "do homem com o homem". A carnavalização, nessa narrativa, vem libertar o indivíduo de todos aqueles dogmas que anteriormente o prendiam a um sistema de poder, indicando novos olhares para os fatos da vida. Do mesmo modo, a cegueira humana é sobrepujada pela ganância, aspecto essencial que une os homens e confirma a tese do narrador: todos acreditaram que ossos humanos podem se transformar em ouro, em um jogo ambivalente entre a crença no discurso do outro e a avareza.

O sobrevivente da arriscada aventura - o Coronel Bentes - prometeu ao povo que na noite seguinte ensinaria a receita, mas eles foram incapazes de esperar essa noite chegar, na mesma data estavam todos no cemitério brigando por cada osso que lá ainda existia, construindo um verdadeiro campo de batalha por ossos. Dessa forma, encenavam a própria carnavalização da vida. A sátira aos costumes estava posta, evidenciando a contradição entre a moral e a cultura do dinheiro.

\begin{abstract}
A desinteligência não tardou a surgir; os mortos eram poucos e não bastavam para satisfazer a fome dos vivos. Houve facadas, tiros, cachações. Pelino esfaqueou o turco por causa de um fêmur e mesmo entre as famílias questões surgiram. Unicamente, o carteiro e o filho não brigaram. Andaram juntos e de acordo e houve uma vez que o pequeno, uma esperta criança de onze anos, até aconselhou ao pai: "Papai, vamos aonde está a mamãe; ela era tão gorda... (BARRETO, 2010, p. 70).
\end{abstract}

O primado da guerra é o Humanitismo, já assinalado por Machado, em que homens brigam entre si em busca da sobrevivência. O relato grotesco da situação se torna gargalhada perante a tragicidade da imagem do filho que aconselha o pai a ir atrás dos ossos da mãe por serem mais gordos, animalizando a vida humana e denotando, por meio 
do exagero da narração da cena, a superação "dos limites de um mundo realmente possível” (PROPP, 1992, p. 92).

Embora haja certa tragicidade no relato, o leitor não vivencia isso ao longo da leitura; na realidade, o estilo narrativo conduz ao riso por meio do exagero dos fatos e da fantasia que encobre o ocorrido. No dia seguinte, na cidade, havia sobrevivido apenas um bêbado que não havia participado da batalha; vangloriando-se de ter toda a bebida do bar sobrado apenas para ele. Esse pobre homem foi ao bar mais próximo e pegou um Parati e o tomou olhando a vida passar. A bela imagem que o narrador nos oferta ao final da narrativa parece a figura do próprio escritor observando a vida passar e rindo desse eterno teatro que é a vida. Era a vitória do conhecimento, da razão, que se sobrepõe à aparência e à ganância de todo um povo. Consideremos o seguinte:

\footnotetext{
Para Bergson, a sociedade e a vida exigem que o homem esteja em constante adaptação, submetido às forças complementares de tensão e elasticidade que a vida coloca em jogo. Quando essas duas forças de adaptação faltam ao corpo, surgem as doenças; quando elas faltam ao espírito, seguem-se a pobreza psicológica e a loucura, e quando elas faltam ao caráter, dá-se a inadequação à vida social, que às vezes leva ao crime. (ALBERTI, 1999, 185).
}

A ideia que o narrador distendeu ao longo da narrativa - retrato da alma humana - procura comprovar a precariedade da ganância. Os homens se matam para conseguir ouro; e o riso que Demócrito derramava sobre a cidade de Abidera, espreitou toda a obra. De forma cômica, o leitor vai rindo das atitudes grotescas das pessoas em nome do dinheiro; se nas crônicas olhamos para os sujeitos que roubam a população, nessa assistimos à morte, ao fim de tudo. "Miserável é a vida dos homens, porque a inevitável ganância os atravessa e lhes cai como um sopro frio, motivo pelo qual seria melhor que todos os médicos viessem reunidos para tratar dessa doença, mais complexa que a loucura, maléfica enfermidade que torna Demócrito feliz” (HIPÓCRATES, 2011, p. 34). A carnavalização da vida aponta a familiarização do homem com o mundo; o distanciamento que se revela entre os sujeitos e as classes sociais. Estas são deixadas de lado, em nome de um mundo onde todos possam lutar por direitos iguais; a aproximação dos homens com seus defeitos, seus dogmas, as ganâncias sociais reverberam no que Bakhtin denomina de mésalliances carnavalescas, unificando a natureza humana na narrativa. Oakley (2011) corrobora tal perspectiva ressaltando que:

A "Nova Califórnia" narra a luta entre duas superstições: a nova superstição do doutor, representada por Bastos, e as superstições primitivas, representadas pelo culto dos mortos, que se evidencia na veneração do cemitério pelo povo. Essa superstição antiga desintegra-se perante a nova devido à cobiça que o próprio Bastos acaba por personificar no desfecho da história. (p. 107). 
Se na crônica o tom de escárnio foi tão evidente, o leitor pode observar claramente o afastamento satírico dessa narrativa. O relato fantástico-ficcional é evidenciado ao longo do enredo, principalmente quando passa para o fabrico de ouro com ossos humanos e a guerra final que leva à morte de todos, apontando a sátira menipeia com "excepcional liberdade de invenção do enredo e filosófica" (BAKHTIN, 2010, p. 130). O aumento estilístico dos fatos procura trazer o riso, apontar e rebaixar a natureza humana. Mas porta-se também como uma forma de narrar leve, brincalhona, que leva o leitor à gargalhada do começo ao fim. Sevcenko (2003) traduz os acontecimentos centrais da narrativa com a seguinte assertiva: "Nas palavras de um cronista coevo, a sociedade se tornava um desabalado torvelinho de interesses ferozes, onde a caça ao ouro constitui a preocupação de toda a gente" (p. 38). No fim de tudo, ficamos com a ambiguidade da figura de herói, e a imagem do grande homem entra em confronto com as ideias de heroísmo, restando apenas o riso de suas ações e de toda a alienação de um povo.

Após uma narrativa em terceira pessoa, passamos agora para o relato em primeira pessoa, com o conto "O homem que sabia javanês" (1911), caricatura à inteligência da cultura brasileira. Esse conto foi escrito logo após Triste Fim de Policarpo Quaresma e, assim como a "Nova Califórnia", são considerados frutos de uma fase de escrita muito especial do prosador carioca.

Aos 30 anos, Lima Barreto atingira o ponto mais alto da sua carreira literária. E produz as suas obras primas. "A nova Califórnia" é de novembro de 1910. "O homem que sabia javanês", de abril de 1911. Foi exatamente no intervalo que escreveu o Triste Fim de Policarpo Quaresma (BARBOSA, 2002, p. 219220).

O segundo conto do prosador, mesmo que seu enredo apresente um tom galhofeiro muito mais acintoso do que o leitor pode encontrar no primeiro, ainda resguarda um alto grau de suspense. Há momentos em que as desventuras de nosso herói poderiam ser descobertas, mas, mesmo sob a tensão, o riso se sobrepõe, e o leitor é contaminado pelo relato engraçado do personagem malandro.

O espaço inicial da narrativa é uma confeitaria, momentos em que o anti-herói, Castelo, narra suas aventuras para sobreviver ao colega Castro. Com a surpresa do amigo em saber que ele viva "tantas aventuras aqui, neste Brasil imbecil e burocrático" (BARRETO, 2010, p. 71), o ideólogo passa a narrar uma de suas principais aventuras e também a que lhe rendeu um cargo no consulado. A narrativa do malandro começa a ser tecida e se assemelha a um conto popular, em que a própria figura do conde se assemelha à de um bufão. Desde o fato de seu interlocutor considerar seu país um espaço de imbecis, 
até a estratégia narrativa que abre a narrativa apontando a vida engraçada como a única forma de sobrevivência. Percebemos como a estrutura do conto convida o espectador a espreitar aquela pequena história narrada de forma muito engraçada, até mesmo nos momentos de maior suspense que a obra oferece. "O absurdo das aventuras de Castelo ilustra o que Arnoni Prado afirmou ser a queda do registro em direção à caricatura flagrantemente humorística da realidade que prevalece cada vez mais na obra de Lima Barreto a partir de 1911-12” (OAKLEY, 2011, p. 124).

O grande caso é como Castelo conseguiu ser professor de javanês sem nunca ter estudado a língua. Após chegar ao Rio de Janeiro e fugir de pensão em pensão por falta de dinheiro para sobreviver na grande capital, o herói viu o anúncio do jornal requisitando um professor de javanês. Ele percebeu rapidamente que essa era sua única chance, pois nenhuma outra pessoa naquele espaço sabia a língua. Por sua vez, ninguém iria contestar seus pressupostos. A astúcia de Castelo se evidencia desde o limiar do enredo, sinalizando a natureza do personagem malandro. Recorreu à biblioteca, estudou um pouco da história da ilha, decorou o alfabeto, algumas palavras e se encaminhou para a casa do Conde que havia colocado o anúncio. "A enciclopédia dava-me a indicação de trabalhos sobre a tal língua malaia e não tive dúvidas em consultar um deles. Copiei o alfabeto, a sua pronunciação figurada e saí. Andei pelas ruas, perambulando e mastigando letras" (BARRETO, 2010, p. 72). A supremacia dos conhecimentos rasos e a aparência tecem o enredo contista: bastava apenas a aparência do aprendizado para obter sua pretensão.

A brincadeira que a personagem estabelece com a população, que desconhece a língua, demonstra o apego aos títulos e à crença no exótico que preponderava na sociedade brasileira: “- Que diabo vem a ser isso, senhor Castelo? Gostei da diversão e ataquei o patriotismo do homem: - É uma língua que se fala lá pelas bandas do timor. Sabe onde é? Oh! Alma ingênua! O homem esqueceu-se da minha dívida...”(BARRETO, 2010, p. 73). A esperteza da personagem para se livrar da dívida sinaliza o livre-trânsito que o homem de títulos possuía dentro da sociedade, demonstrando a facilidade de enganar as pessoas apenas com a dissimulação de algum conhecimento: o estudo que se afincou simplesmente no alfabeto e na história da língua oceânica denunciava a aparência e uma espécie de filiação aos conhecimentos rasos. A forma fácil de ganhar a vida que sempre o acompanhou denunciava a natureza de muitos homens que se revestiam por trás dos títulos para conseguirem posições renomadas. Mais além dessa faceta, também levantava do túmulo uma grande tradição de personagens malandros, entre as quais o 
leitor brasileiro rapidamente lembrará do Sargento de Milícias com o grande desapego ao trabalho.

O homem que requisitou o professor era o doutor Manuel Feliciano Soares de Albernaz, o barão de Jacuecanga. A descrição da residência da figura denuncia toda uma tradição de vida por trás do patriarcado.

\footnotetext{
Na sala, havia uma galeria de retratos: arrogantes senhores de barba em colar se perfilavam enquadrados em imensas molduras douradas, e doces perfis de senhoras, em bandos, com grandes leques pareciam querer subir aos ares, enfunadas pelos redondos vestidos de balão" (BARRETO, 2010, p. 74).
}

O velho queria aprender a vasta língua para ler um livro, herança de seu avô, mas sua idade o impedia de decorar aqueles ensinamentos; perante o reconhecimento de sua incapacidade pediu apenas para nosso herói ler o livro para ele. É exatamente a partir de agora que o leitor passa a dar diversas gargalhadas perante o incontido fato, pois a narrativa nada corresponde às posições do livro, Castelo inventa toda uma trama para ludibriar o barão. "Sabes bem que até hoje nada sei de javanês, mas compus umas histórias bem tolas e impingi-as ao velhote como sendo do Crônicon. Como ele ouvia aquelas bobagens!...” (BARRETO, 2010, p. 76).

A ironia da narração de Castelo se exacerba ao relatar a Castro a admiração do marido da filha do barão, homem poderoso e importante, pelo professor de javanês, que em tão tenra idade sabia a língua. O exotismo dá fama ao narrador; por outro lado, é visto como uma das principais críticas levantadas, uma vez que o desconhecido se tornava sinônimo de sabedoria. Perante a nova posição social - sai da extrema pobreza e passa a ocupar um dos cargos mais altos de uma nação - o narrador relata os diversos benefícios que ganhou com a estada na nova residência, quase acreditando ele mesmo que o ganho da herança que o barão herdou deveu-se ao seu ensinamento de javanês. A narrativa, a cada descrição, torna-se mais cômica, e as cenas de suspense começam a surgir perante o medo do protagonista de ser descoberto em sua carreira falseada. O leitor se vê, nesse momento, frente a um herói que construiu seu próprio heroísmo, e quando a esse herói é ofertado um alto cargo, como o da diplomacia, procura todos os modos para não assumir: "Fiz-lhe todas as objeções: a minha fealdade, a falta de elegância, o meu aspecto tagalo" (BARRETO, 2010, p. 77); para não descobrirem sua farsa.

A personagem malandra parece caminhar por toda uma tradição de literatura. A vida fácil que procurava encontrar na cidade grande era apenas uma convicção que o acompanhava e que sabia ser a fórmula que todos aqueles grandes homens públicos 
conseguiam crescer cada dia mais em seus ambientes de trabalho. O que se avistava no trabalho, na realidade, não passava de eterno jogo de relações, herança ainda de um sistema de apadrinhamento que circulava na sociedade carioca e possibilitava sujeitos tão mesquinhos de conhecimento a conquistar cargos tão elevados. Além disso, grandes conhecedores se mantinham em posições inferiores por não ter um grande homem para os indicar a cargos memoráveis. Em contrapartida, o atraso de pensamento que acompanhava a população carioca, reafirmado por uma comunidade de homens alienados, marcava o espaço do riso e a necessidade de mudança que a escritura gritava. O rebaixamento das atitudes da população era um clamor à mudança.

Diante da imagem do herói contista, é importante lembrar a faceta de uma outra personagem, o doutor Bogóloff, protagonista de As aventuras do doutor Bogóloff. Natural da Rússia, frente à necessidade de sair da pátria devido aos problemas que o local estava tendo, o narrador foi atraído para o Brasil devido às enormes propagandas que o país ofertava para os estrangeiros. Entretanto, ao chegar e passar um bom tempo investindo todo o seu conhecimento para obter condições de vida dignas, Bogóloff percebeu que o manejo da situação no Brasil era diferente: não serviam ao país a honestidade e o trabalho, tudo era realizado por meio do apadrinhamento e do jogo de relações estabelecidas. Foi por essa arriscada vida que o herói passou a vagar, conseguindo posições renomadas e sendo indicado a diversos cargos importantes. Esse também foi o destino de Castelo; entretanto, o herói brasileiro não perdeu seu tempo com atos de honestidade, porque sabia por onde andava o pensamento de sua pátria, sendo certeiro quando escolheu a profissão que devia seguir. Tais descrições evidenciam, por meio das máscaras desses narradores, a atitude crítica do autor perante o sistema de vida da população carioca.

A narrativa de Castelo, entretanto, foi tão acintosa que convenceu com uma mestria seu grande tutor, sendo recomendado para diversos órgãos importantes, inclusive para um congresso de Linguística para falar sobre a língua de Java, sem nunca ter aprendido a língua. A narrativa expõe um fato muito importante: Castelo, mesmo sendo beneficiário de diversas regalias, obtendo muitas oportunidades de aprender corretamente a língua, a qual passou a lhe dar glórias, não tinha vontade, pois sem o conhecimento havia conquistado o que tanto precisava: "Bem jantado, bem vestido, bem dormido, não tinha energia necessária para fazer entrar na cachola aquelas coisas esquisitas" (BARRETO, 2010, p. 78). O ter gera o comodismo e não deixa o sujeito ir atrás daquilo de que precisa. $\mathrm{O}$ comodismo que os títulos davam ao homem não possibilitava a busca 
sedenta de conhecimento, contribuindo largamente para a decadência e o fracasso da inteligência do país.

Foi-lhe, por fim, concedido o título de cônsul que mantém até o momento que narra a história para seu amigo, sem nunca aprender nada daquela língua. A narrativa é quase inacreditável; todavia, leva o leitor a acreditar em determinado ato porque reside no Brasil. País que se encapsula em definições deslizantes e pertencentes ao linguajar da doxa e do vulgo: país aberto a todo tipo de falcatrua para quem tem um título em mãos e uma boa lábia. Os títulos se mantêm, infelizmente, como critério principal para o sujeito se dar bem na vida. Daí, essência e aparência, mais uma vez, entrarem em choque, restando apenas o riso, não das atitudes desse anti-herói brasileiro, mas de todos aqueles que aplaudem em pé suas atitudes e as tornarem possível na esfera das representações públicas. A conclusão a que Lima Barreto chega, a partir da época em que escreveu Triste fim de Policarpo Quaresma e "O homem que sabia javanês", "é que o mundo pertence àqueles que simplesmente exploram os aspectos exteriores e superficiais do saber e da inteligência, enquanto todos os outros são vítimas das limitações ou da fragilidade da inteligência" (OAKLEY, 2011, p. 197).

As análises encetadas nesta dissertação, seletivamente, no terreno dos contos, chegam ao cabo em "Apologética do Feio". Vale a observação: se, por um lado, a narrativa curta carrega em suas linhas traços trágicos pela miserabilidade da condição humana; por outro, o título, por si só, conduz o leitor ao riso. O enredo da parca história narra os fatos de um acontecimento simplório - uma senhora se recusa a dançar uma valsa com o protagonista por causa de feiura dele. Ato esse não tão comum, mas que feriu a honra do célebre homem que fora menosprezado por mesquinho fato. A pieguice do narrador, ao contar a pilhéria, leva o leitor ao riso, desde o tom com o qual procura escrever o bilhete, e a resposta à sua alta nobreza que lhe advém de longa descendência “a venerabilíssima família dos feios” (BARRETO, 2010, p. 556).

O grotesco da aparência é uma das principais formas de comicidade existente. Sobre tal aspecto, a literatura, ao longo dos tempos, entreteve-se largamente com o aspecto cômico de suas personagens, a fim de desvelar o ridículo. Desde um nariz grande e disforme - aspecto central utilizado pelos palhaços para provocar a gargalhada -, o rosto, os olhos de uma pessoa, até o cheiro de certas damas, como aponta Propp. Em largos e certeiros traços: em especial, o corpo humano leva ao riso. Vejamos: a figura do bobo da corte, do palhaço, do asno, por exemplo, são imagens cômicas que atravessaram 
a história da cultura cômico-popular no decorrer dos tempos. Lima Barreto, em suas escrituras, brinca constantemente com o aspecto físico de suas personagens, o que reflete claramente o porquê de escrituras trágicas, relatos tristes ainda serem motivo de riso. Esse é o caso dessa narrativa que, ao mesmo tempo em que denuncia um certo preconceito advindo de uma senhora, joga com os aspectos risíveis. Ao mesmo tempo que o herói brinca com a pequena anedota, leva seu leitor à reflexão sobre o assunto, visibilizando as ações cômicas cotejadas por questões morais.

A continuidade do enredo aponta diversos autores da tradição literária mundial que, em sua concepção, são considerados feios, mas que se tornaram grandes homens, denunciando que a aparência externa jamais importou às pessoas. Porém, os conhecimentos que poderiam fazer infligir no seio de uma sociedade. "Aristófanes, o desabusado autor das Nuvens e dos Cavaleiros, o fundador deste culto em que mais tarde pontificaram o inimitável Karv e o incompatível Eça - era um aborto” (BARRETO, 2010, p. 557). Se a população brasileira dava tanta atenção ao aspecto físico de um povo, em detrimento do conhecimento que se poderia ter, é porque as ações estavam deslocadas, os pensamentos trocados. Essa história galhofeira, tão simples quanto possa ser, também representava algo que importunava Lima Barreto e que evidenciava, em seus escritos, a boa aparência e o lustro de gestos e de discursos ao falar das características que a sociedade enxergava nos grandes literatos de sua época. Contrariamente, não eram apenas os autores que prescindiam de tais qualificativos, como bem podemos encontrar em outras narrativas; toda a sociedade padecia desse mal de encenações, revelando a máquina motivadora do jogo da vida em sociedade. Conforme Barreto situa a aparência vulgar (comum) nas representações da vida, em "O destino da literatura" ele pontua: "Pede tal gênero ao expositor desembaraço e graça distinção de pessoa, capricho no vestuário e quem sabe lá? - beleza física e sedução pessoal". Em seguida complementa: "E o critério nacional de que tenho muitas provas nas torturas por que têm passado aqueles meus amigos e confrades aos quais Deus galardoou com tão raras virtudes" (BARRETO, 1956, p. 51).

A beleza era o artifício essencial para a sociedade, não importavam as outras qualidades do sujeito; ademais, o conto em questão questiona exatamente até onde o padrão de beleza faz jus a quem o carrega. Com expressões como fealdade heroica, o herói foi destacando o caso de importantes escritores como Dante, Kant, Descartes, por exemplo, procurando comprovar sua ideia de uma fealdade que depende tanto do ponto 
de vista de quem está olhando, quanto do local, do espaço e do momento histórico do observador. A conclusão que o protagonista chegou ao término da narrativa é que, quando sua patroa resolveu lhe ferir, acabou atacando toda uma tradição de homens, que, se ditos feios por fora, são criadores de diversas obras e inscreveram seus nomes na história mundial, na história do conhecimento; qualidade essa tão desprezada por aquele grupo de povos que faziam a história de um Rio de Janeiro ao qual, embora cheio de belezas, não faltava o ingrediente essencial, que seria, no caso, uma população marcada pelo jogo das aparências.

Ao longo do transcurso dessas narrativas de Lima Barreto, percebemos a construção de narradores que caminham sempre por meio de uma tese principal e procuram no decorrer das tramas narradas comprovar suas ideias. A natureza humana parece que está sempre em constante avaliação, e a cada narrativa escrita, uma nova face da cidade carioca, ou também do Brasil, ia se constituindo, ia sendo cartografada em um amplo palco carnavalizado, uma comunidade de máscaras. A respeito desse aspecto, Bakhtin afirma: "O romancista precisa de alguma espécie de máscara consistente na forma e no gênero que determine tanto a sua posição para ver a vida, como também a posição para tornar pública essa vida" (BAKHTIN, 2014, p. 277). Cada personagem é apenas mais um símbolo das ruas e dos cidadãos do Rio de Janeiro, cada um com seus vícios e defeitos. Mais que a pátria brasileira, é a própria natureza humana que parece ser desmembrada, visto que o Brasil foi apenas o experimento para a comprovação de tese e de um povo vivendo de suas ilusões perdidas.

Walter Benjamin (2012) alerta para o seguinte: a história se aproxima do mito, mas é passível de ser recontada, porque relembra as histórias orais transmitidas de boca em boca por uma população, passando a ser lida enquanto conto popular. Para esta dissertação, observamos que a grandeza dos três contos analisados repousa no distanciamento narrativo, podendo, simbolicamente, ceder ao mito. O retorno às tradições orais, das quais o conto é herdeiro, coloca o leitor em confronto com uma verdade ou ensinamento que vai sendo transmitido ao longo da história e que ganha tons de verdade, diante de constante reprodução. Essa ideia é exaustivamente enfatizada por Mikhail Bakhtin como traço fundamental das narrativas romanescas, ou seja, decalca-se desse pensamento axiológico o entrelaçamento entre o conto e as escrituras surgidas após a ascensão do romance, denotando uma configuração narrativa que se vale do riso como forma nodal de composição discursiva. 


\section{CONCLUSÃO DE UMA HISTÓRIA}

Felizes os tempos de Rabelais: a borboleta do romance voa levando em seu corpo os restos da crisálida. [...] O momento excepcional do nascimento de uma nova arte dá ao livro de Rabelais uma riqueza inacreditável; tudo está ali: o verossímil e o inverossímil, a alegoria, a sátira, os gigantes e os homens normais, as anedotas, as mediações, as viagens reais e fantásticas, as controvérsias eruditas, as digressões de puro virtuosismo verbal. O romancista de hoje, herdeiro do século XIX, experimenta uma nostálgica inveja desse universo extraordinariamente heteróclito dos primeiros romancistas e da alegre liberdade com a qual o habitavam. (KUNDERA, 1994, p. 03). 
O texto literário pode ser lido como um meio de intervenção social e como sintoma da cultura. Mesmo ciente que um escrito (obra de arte) não consegue de traduzir a vida, os discursos e enunciados literários vão se aglomerando na escritura, delegando vozes a partir de variados pontos de vista, pluralizando os contextos de recepção e metamorfoseando a sociedade em seus avanços, retrocessos, rupturas e superações. A capacidade crítica do escritor de pensar o mundo e a linguagem, pela qual irá representar esse grande cosmo social, é também uma forma plural de composição de enunciados risíveis. Escrever uma história de forma cômica é, desse modo, reencenar a vida, é escolher uma linguagem que encapsule alegrias e tristezas sociais a um só tempo.

A obra de arte, nesse sentido, passa a ser vista como testemunho de uma época, que, por meio dos fingimentos narrativos, tece um grande legado literário, em que o histórico e o literário se unem em torno de um mesmo plano: a representação da vida. $\mathrm{O}$ universo ficcional é o espaço para o autor criar um povo que não existe, um mundo próprio, experimentar suas ideias acerca de um cotidiano possível e lógico, obedecendo aos preceitos aristotélicos. Foi dessa forma que a história literária confrontou o próprio tempo. A deflagração do romance enquanto gênero basilar para a representação da vida humana abriu espaço para produções totalmente vinculadas com a existência do homem. O rebaixamento do herói, a carnavalização da vida, o diálogo entre gêneros e a ambivalência social construíram um novo tipo de herói, representado, em especial, sob a imagem do discurso de rebaixamento, da equalização discursiva e da familiarização humana, se possível, com laivos de uma pequena amorosidade.

Dentro desses meandros, Lima Barreto passa a ser visto através do prisma de uma tradição literária na qual o risível se tornou um dos principais componentes dos enredos narrativos. Escritor em diversos gêneros, o prosaísta carioca em estudo confronta os acontecimentos sociais de sua época por meio da linguagem cômica e da simbólica carnavalesca, em que o homem oficial perde sua coroa e se unifica aos demais cidadãos, aproximando os sujeitos e contrastando as visões sociais que marcaram a Primeira República brasileira. Ao trazer o plano filosófico da vida para as imagens literárias, o escritor transferiu a filosofia do particular para o âmbito público, fazendo com que aqueles fatos restritos à vida não oficial fossem expostos para serem dialogados e confrontados. O objetivo final que os narradores barreteanos querem evidenciar por meio do discurso risível, além da grande crítica que o autor procura deixar sobre a situação social do Brasil na época, é que não existem mais heróis - são apenas humanos com todos 
os defeitos deixados para o homem. Assim, não se necessita de construir um púlpito para pôr pessoas iguais a nós.

As obras barreteanas estudadas parecem vagar por meio dessa ideia. As relações do sujeito com o mundo e a alegoria social representada compõem uma arquitetônica dos problemas sociais que o autor reconhecia em seu meio. Eram as verdades de mundo do autor transformadas em imagens artísticas. Tais relações, que percorrem a obra desde o primeiro romance, Recordações do Escrivão Isaías Caminha, vão constituindo o projeto estético e ideológico do romancista, que enxergava, no espaço literário onde estava inserido, os principais problemas e suas circunstâncias. Logo, a falta de associação entre a obra literária e o mundo, torna-se uma das fontes precípuas de crítica do romancista, momentos em que se reconhecem, na maioria de suas obras, personagens girando a face para o descaso da arte; forma de ironizar e rebaixar os intelectuais das letras.

Tais ideias, notadamente, abrem o primeiro capítulo de Os Bruzundangas. No conjunto de crônicas, que parte da paródia de um grande livro satírico, "Arte de furtar", o resultado foi, visivelmente, a apropriação crítica que a obra ofertava. Assim como Gregório de Matos fez com a Bahia, Lima Barreto projetou na cidade do Rio de Janeiro toda a sua verve crítica: mediante o deslocamento narrativo, destronou o espaço social carioca e denunciou não só as fragilidades do governo e da literatura, como também o grupo de cidadãos bestializados, semelhante a um amontoado de heróis despossuídos de ações titânicas. Percebemos que o olhar para os diversos seguimentos sociais produziu na obra barreteana um grande reflexo satírico do espaço, onde os elementos de rebaixamento foram centrais na construção da crítica social, fazendo da comicidade o componente primordial para composição da história narrada.

Os contos, por sua vez, apontam um plano narrativo diverso, em que o suspense ainda persiste, e a ironia se destaca como ponto central do enredo narrativo. Por meio do conto "Nova Califórnia", o leitor é convidado a mergulhar no mundo das ilusões e da ganância, em que a comicidade é moradia certa para se encontrar a moral da história. Assim, a projeção cômica é a forma alegre de denunciar a ganância social e a alienação humana. Na segunda história (“O Homem que Sabia Javanês”), encontra-se o apego aos títulos e às honrarias como centro do enredo narrativo, e, para finalizar, no conto "Apologética do Feio", foi exposta a aparência como modo de olhar da sociedade. 
Dessa forma, constatamos que o destino da literatura cruza os temas desses três contos, uma vez que era possível perceber uma sociedade alienada por um grupo de escritores resguardados apenas pelos títulos e pela aparência social, na qual as senhoras, nas palavras do prosador, se interessavam apenas pela formação do indivíduo, conduzindo para a comicidade. Ainda vale destacar que as ilusões perdidas são as ilusões de todo um povo, de uma sociedade, massacrada pelo poder dominante, restando ao artista se sobrepor a elas e retratar, sem nenhum temor, as desgraças e misérias da natureza humana, encontrando no riso a liberdade de representação de todo aquele espetáculo público mediado pelas máscaras sociais usadas no jogo das aparências.

Nas narrativas barreteanas, ficaram cabalmente assinaladas as imagens das personagens como imagens do sujeito no mundo, com suas misérias e sofrimentos, com suas alegrias e tristezas. Tais imagens dão a face de maneira travestida - com seus traços carnavalizados, risíveis. Esse conjunto de características não diminui o homem perante o outro, mas revela a própria natureza humana e sua indissociabilidade com o mundo do riso, mítica e historicamente. O riso, no fim de tudo, une os homens em torno de um núcleo, que no fim, é o homem em sua humanidade.

O inacabamento da obra literária é visto como sua atualização no tempo. Ao pegarmos uma obra do início do século XX, como a de Lima Barreto, e lermo-la sob a lente da contemporaneidade podemos vir a reconhecer que os temas retratados nesse escrito se mantêm vivos na atualidade. Questões como falta de acesso à cultura de determinadas camadas sociais, política, essência e aparência, entre vários outros assuntos que o escritor carioca problematizou em sua escritura são universais e não deixam de ser vistas nas várias épocas que marcaram a história. Esses são alguns dos motivos essenciais que se pode deduzir da vastidão da obra literária barreteana, a qual se reatualiza a cada novo leitor no fluir do tempo.

Enfatizamos, mas não encerrando o tema desta dissertação, que a filosofia de um homem não foi o suficiente para salvar a doença da humanidade, e a fenda que dele foi retirada apenas o tornou um estranho no meio de seu povo. O riso de Hipócrates foi a fórmula encontrada para tentar superar os problemas sociais que culminavam em sua época, tecendo uma história para a qual a loucura foi o ponto final. Ele poderia falar dos males da humanidade, mas jamais curar o mundo desse mal. Pois como proferia Pandora, a vida é apenas um empréstimo que a grande Natureza concedeu ao homem, fazendo de nossa passagem pela terra apenas um passeio. 


\section{Referências}

ACHCAR, Francisco. Introdução. In: ALMEIDA, Manuel Antônio de. Memórias de um sargento de milícias. São Paulo: Objetivo, 1996.

ALAVARCE, Camila da Silva. A ironia e suas reflexões: um estudo sobre a dissonância na paródia e no riso. São Paulo: Cultura Acadêmica, 2009.

ALBERTI, Verena. O riso e o risível na história do pensamento. Rio de Janeiro: Jorge Zahar, 1999.

ALMEIDA, Manuel Antônio de. Obra dispersa. Rio de Janeiro: Graphia, 1991.

. Memórias de um sargento de milícias. São Paulo: FTD, 1996.

ANÔNIMO: Arte de furtar. Porto Alegre: L\&PM, 2005.

ARISTÓTELES. Poética. Tradução de Eudoro de Sousa. Lisboa: Imprensa Nacional, 1992.

ASSIS, Machado. A cartomante e outros contos. São Paulo: Moderna, 1995.

Memórias Póstumas de Brás Cubas. Porto Alegre: L\&PM, 2013.

Quincas Borba. Porto Alegre: L\&PM, 2008.

AUERBACH, Erich. Mimesis: A representação da realidade na literatura Ocidental. São Paulo: Perspectiva, 2011.

BAKHTIN, Mikhail. A cultura popular na idade média e no renascimento - o contexto de François Rabelais. Tradução de Yara Frateschi Vieira. 8. ed. Brasília: Editora Universidade de Brasília, 2008.

Questões de Literatura e de Estética: a teoria do romance. Tradução de Aurora Fornoni Bernardini. 7. ed. São Paulo: Hucitec, 1990.

Estética da Criação Verbal. Tradução de Paulo Bezerra. 6. ed. São Paulo: Martins Fontes, 2011.

. Problemas da poética de Dostoiévski. Tradução de Paulo Bezerra. 6. ed. Rio de Janeiro: Forense Universitária, 2010.

Para uma filosofia do ato responsável. Tradução de Valdemir Miotello e Carlos Alberto Faraco. São Paulo: Expressão Popular, 2010.

BARBOSA, Francisco de Assis. A vida de Lima Barreto. Rio de Janeiro: José Olympio, 2002.

BARRETO, Lima. Diário do Hospício e o Cemitério dos Vivos. São Paulo: Cosac Naify, 2010. 
Recordações do Escrivão Isaías Caminha. Rio de Janeiro: Nova Fronteira, 2012. . Clara dos Anjos. Rio de Janeiro: Escala, 2011.

. Histórias e sonhos. São Paulo: Martins Fontes, 2008.

. Triste Fim de Policarpo Quaresma. Rio de Janeiro: Media fashion, 2008.

. Os Bruzundangas. Porto Alegre: L\&PM, 2010.

Contos completos de Lima Barreto. Organização e introdução Lilia Moritz

Schwarcz. São Paulo: Companhia das Letras, 2010.

. Impressões de Leitura. São Paulo: Brasiliense, 1956.

BENJAMIN, Walter. Magia e técnica, arte e política: ensaios sobre literatura e história cultura. Tradução de Sergio Paulo Rouanet. São Paulo: Brasiliense, 2012.

BERGSON, Henri. O riso: ensaio sobre a significação do cômico. Rio de Janeiro: Zahar Editores, 1983.

BOSI, Alfredo. História concisa da literatura brasileira. 42. ed. São Paulo: Cultrix, 2004.

BUENO, Alexei. Antologia pornográfica: de Gregório de Matos a Glauco Mattoso. Rio de Janeiro: Nova Fronteira, 2011.

CANDIDO, Antonio. A vida ao rés-do-chão. In: ANDRADE, Carlos Drummond et al. (Org.) Para gostar de ler. São Paulo: Ática, 1979. V. 5: Crônicas. P. 13-22.

O discurso e a cidade. Rio de Janeiro: Ouro sobre Azul, 2010.

A educação pela noite. Rio de Janeiro: Ouro sobre Azul, 2011.

CARVALHO, José Murilo de. Os Bestializados: o Rio de Janeiro e a República que não foi. São Paulo: Companhia das Letras, 1987.

CASTELlo, José Aderaldo. Realidade e ilusão em Machado de Assis. São Paulo: Companhia Editora Nacional, 1969.

CASTRO, Ruy. Maneco: o autor que escreveu sua obra prima aos vinte anos - e levou os dez restantes a caminho do oblívio. In ALMEIDA, Manuel Antônio de. Memórias de um Sargento de Milícias. São Paulo: Penguin \& Companhia das Letras, 2013. P. 7-28.

CERVANTES, Miguel. O engenhoso Fidalgo D. Quixote da Mancha. São Paulo: Abril, 2010. Vol. I.

CORTÁZAR, Julio. Valise de cronópio. Trad. Davi Arrigucci Jr. e João Alexandre Barbosa. São Paulo: Perspectiva, 2006. 
CURY, Maria Zilda Ferreira. Um mulato no Reino de Jambom: as classes sociais na obra de Lima Barreto. São Paulo: Cortez Editora, 1981.

DELEUZE, Gilles. Crítica e clínica. Tradução de Peter Pal Pelbart. São Paulo: ed. 34, 1997.

DOSTOIÉVSKI, Fiodor. Dostoiévski: "bobók”. Tradução e análise do conto de Paulo Bezerra. São Paulo: Editora 34, 2005.

FERNANDES, Dirce Lorimie. Gregório de Matos e Guerra: o Rabelais dos trópicos. VARIA HISTÓRIA. Belo Horizonte: ed. UFMG, 2000. Semestral. p.109-130.

FONSECA, Laura Goulart. A sátira em Machado de Assis. 1996. 115 f. Dissertação (Mestrado em Literatura). Instituto de Letras, Universidade de Brasília. Brasília, 1996.

FREIRE, Zelia Nolasco. Lima Barreto: imagem e linguagem. São Paulo: Annablume, 2005.

FREITAS, Luciana Gomes Lima de. Lima Barreto e a Primeira República: uma leitura da sátira nas crônicas Os Bruzundangas. 2001. 109 f. Dissertação (Mestrado em Literatura). Instituto de Letras, Universidade de Brasília, Brasília, 2011.

FREITAS, Maria Eurides Pitombeira de. O grotesco na criação de Machado de Assis e Gregório de Matos. - Rio de Janeiro: Presença, 1981.

FRYE, Northrop. Anatomia da Crítica. Tradução de Marcus de Martini. São Paulo: Realizações, 2014.

GERMANO, Edilva Maria Pires. Alegorias do Brasil: imagens de brasilidade em Triste Fim de Policarpo Quaresma e Viva o povo brasileiro. São Paulo: Annablume, 2000.

GÓGOL, Nicolay. O capote e outras histórias. São Paulo: Editora 34, 2010.

GOTLIB, Nádia Bottella. Teoria do conto. São Paulo: Ática, 2006.

HANSEN, João Adolfo. A sátira e o engenho: Gregório de Matos e a Bahia do século XVII. São Paulo: Companhia das Letras, 1989.

HIPÓCRATES. Sobre o riso e a loucura. São Paulo: Hedra, 2011.

HUGO, Victor. O homem que ri. São Paulo: Estação Liberdade, 2014.

KUNDERA, Milan. Os testamentos traídos: ensaios. Tradução de Teresa Bulhões de Carvalho da Fonseca. Rio de Janeiro: Nova Fronteira, 1994.

LINS, Osman. Lima Barreto e o espaço romanesco. São Paulo: Ática, 1976.

LOBATO, Monteiro. Lima Barreto. In: BARRETO, Lima. Triste fim de Policarpo Quaresma. São Paulo: ALLCA XX, 1997. P.425-426. 
LOYOLLA, Dirlenvalder do Nascimento. Bagatelas e Marginália: cultura intelectual e revide ao poder nas crônicas de Lima Barreto. 2014. 199. F. Tese (Doutorado em Literatura). Instituto de Letras, Universidade de Brasília, Brasília, 2014.

LUKÁCS, G. “O Romance como Epopeia Burguesa”. Traduçao de Letizia Zinj Antunes. Revista Ad Hominem 1, Tomo II, Música e Literatura. São Paulo: Ad Hominem, 1974. P. 87-117.

MATOS, Gregório. Poemas escolhidos. São Paulo: Companhia das Letras, 2010.

MENDONÇA, Bernardo de. D'Almeida, Almeida, Almeidinha, A., Maneco, Um Brasileiro: mais um romance de costumes. In ALMEIDA, Manuel Antônio. Obra dispersa. Rio de Janeiro: Graphia, 1991. P. XI - XXXVIII.

MEYER, Augusto. Machado de Assis. Rio de Janeiro: Livraria São José, 1958.

MINOIS, Georges. História do Riso e do Escárnio. São Paulo: Unesp, 2003.

NIETZSCHE, Friedrich. Verdade e mentira no sentido extramoral. COMUM. Rio de Janeiro: Facha, 2001. Semestral.

NOGUEIRA, Carlos. A sátira em Gregório de Matos. Línguas e letras, 2011, pgs: 271285.

OAKLEY, R. J. Lima Barreto e o destino da literatura. São Paulo: Unesp, 2011.

PRADO, Antonio Arnoni. Lima Barreto: o crítico e a crise. Rio de Janeiro: Cátedra; Brasília, INL, 1976.

Lima Barreto: uma autobiografia literária. São Paulo: Editora 34, 2012.

PROPP, Vladimir. Comicidade e riso. Tradução Aurora Fornoni Bernardini e Homero Freitas de Andrade. São Paulo: Editora Ática, 1992.

RABELAIS, François. Gargantua e Pantagruel. Belo Horizonte: Villa Rica Ed. Reunidas, 1991.

RAMOS, Graça. Ironia à brasileira: O enunciado irônico em Machado de Assis, Oswald de Andrade e Mario Quintana. São Paulo: Paulicéia, 1997.

ROBERT, Marthe. Romance das origens, origens do romance. São Paulo: Cosac Naify, 2007.

SAMÓSATA, Luciano. Diálogo dos mortos. São Paulo: Palas Athena, 1996.

SANTANA, Débora Betânia. IRONIA: O TEMPERO DA CRÔNICA (estudo de textos cronísticos de Luís Fernando Verissimo): 2006. 88 f. Dissertação (Mestrado em literatura). Departamento de Letras, Pontifícia Universidade Católica de São Paulo São Paulo, 2006. 
SCHAEFER, Sérgio. Dialogismo, polifonia em Dostoiévski. Bakhtiniana, São Paulo, 6 (1): 194-209, ago/dez, 2011.

SCHOPENHAUER, Arthur. O mundo como vontade e como representação. São Paulo: Editora Unesp, 2005.

SEVCENKO, Nicolau. Literatura como missão: tensões sociais e criação cultura na Primeira República. São Paulo, Companhia das Letras, 2003.

SOUZA, Ronaldes de Melo. O romance tragicômico de Machado de Assis. Rio de Janeiro, EdUERJ, 2006.

SILVA, Tiago Ferreira. "Franjas de algodão em manto de veludo": apropriação irônica e realidade histórica nos contos de temática religiosa de Machado de Assis. 2013. 123 f. Dissertação (Mestrado em Literatura). Instituto de Letras, Universidade de Brasília Brasília, 2013.

TEIXEIRA, Ivan. Apresentação de Machado de Assis. São Paulo: Martins Fontes, 2013.

TELAROLLI, Silvia. Entre a fúria e a esperança, o fel e o riso: presença da sátira na literatura brasileira. In: SEGATTO, José Antônio; BALDAN, Ude. Sociedade e Literatura no Brasil. São Paulo: UNESP, 1999.

WALDMAN, Berta. O romântico fruto de uma pisadela e de um beliscão. In: ALMEIDA, Manuel A. de. Memórias de um sargento de milícias. São Paulo: FTD, 1992. P. 7-12.

WATT, Ian. A ascensão do romance. Tradução de Hildegard Feist. São Paulo: Companhia das Letras, 2010.

ZILLY, Berthold. A pátria entre paródia, utopia e melancolia. ESTUDOS SOCIEDADE E AGRICULTURA. Rio de Janeiro: UFRJ, 2003. 